\title{
Spent Nuclear Fuel Shipping Cask Handling Capabilities of Commercial Light Water Reactors
}

P. M. Daling

G. J. Konzek

A. J. Lezberg

E. F. Votaw

M. I. Collingham

April 1985

Prepared for the U.S. Department of Energy under Contract DE-AC06-76RLO 1830

Pacific Northwest Laboratory Operated for the U.S. Department of Energy by Battelle Memorial Institute 


\title{
DISCLAIMER
}

This report was prepared as an account of work sponsored by an agency of the United States Government. Neither the United States Government nor any agency thereof, nor any of their employees, makes any warranty, express or implied, or assumes any legal liability or responsibility for the accuracy, completeness, or usefulness of any information, apparatus, product, or process disclosed, or represents that its use would not infringe privately owned rights. Reference herein to any specific commercial product, process, or service by trade name, trademark, manufacturer, or otherwise, does not necessarily constitute or imply its endorsement, recommendation, or favoring by the United States Government or any agency thereof. The views and opinions of authors expressed herein do not necessarily state or reflect those of the United States Government or any agency thereof.

\author{
PACIFIC NORTHWEST LABORATORY \\ operated by \\ BATTELLE \\ for the \\ UNITED STATES DEPARTMENT OF ENERGY \\ under Contract DE-AC06-76RLO 1830
}

\begin{tabular}{|c|c|}
\hline \multicolumn{2}{|c|}{ Printed in the United States of America } \\
\hline \multicolumn{2}{|c|}{ Available from } \\
\hline \multicolumn{2}{|c|}{$\begin{array}{l}\text { National Technical Information Service } \\
\text { United States Department of Commerce }\end{array}$} \\
\hline \multicolumn{2}{|c|}{ United States Department of Commerce } \\
\hline \multicolumn{2}{|c|}{5285 Port Royal Road } \\
\hline \multicolumn{2}{|c|}{ Springfield, Virginia 22161} \\
\hline \multirow{2}{*}{\multicolumn{2}{|c|}{$\begin{array}{l}\text { NTIS Price Codes } \\
\text { Microfiche A01 }\end{array}$}} \\
\hline & \\
\hline \multicolumn{2}{|c|}{ Printed Copy } \\
\hline & Price \\
\hline Pages & Codes \\
\hline $001-025$ & A02 \\
\hline $026-050$ & A03 \\
\hline $051-075$ & A04 \\
\hline $076-100$ & A05 \\
\hline $101-125$ & A06 \\
\hline $126-150$ & A07 \\
\hline $151-175$ & $\mathrm{~A} 06$ \\
\hline $176-200$ & $A 09$ \\
\hline $201-225$ & $A 010$ \\
\hline $226-250$ & A011 \\
\hline $251-275$ & A012 \\
\hline $276-300$ & A013 \\
\hline
\end{tabular}


PNL -5384

TTC-0535

UC-71

SPENT. NUQLEAR FUEL SHIPPING CASK

HANDL ING CAPAB IL ITIES OF

COMNERCIAL LIGHT WATER REACTORS
P. M. Daling
G. J. Konzek
A. J. Lezberg,
E. F. Votaw (a)
M. I. Collingham

Apr $\| 1985$

Prepared for

the U.S. Department of Energy

under Contract DE-AC06-76RL 01830

Pacl if ic Nor thwest Laboratory

Richland, washington 99352

(a) Rockwell Hanford Operations

Richl and, Washington 99352 


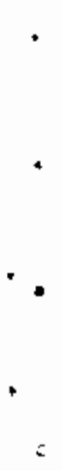

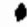




\section{ABSTRACT}

Real istic truck/rail modal fractions (defined as the fraction of spent fuel that $11 \mathrm{l}$ be recelved by truck and rall transport modes) are needed to support the designs of federally-owned or operated spent $f$ uel storage or disposal facilities. Information is also needed on the spent fuel shipping cask handling capabilities of commercial nuclear power plants. This report describes an evaluation of the cask handling capabilities of those reactors wich are operating or under construction. A computerlzed data base that includes cask handling information was developed ith information from the literature and utllity-supplied data. The capabil ity of each plant to recelve and handie existing spent fuel shipping casks was then evaluated. Modal fractions were then calculated based on the results of these evaluations and the quantities of spent fuel projected to be generated by commerclal nuclear power plants through 1998 .

The results indlcated that all plants are capable of recelving and hand ing truck casks. Up to 118 out of 130 reactors (91\%) could potentially handle the larger and heavler rail casks if the maximum capability of each facllity is utllized. Design and analysis efforts and physical modifications to some plants would be needed to achieve this high rall percentage. These modifications would be needed to satisfy regulatory requlrements, increase I ifting capabilities, develop rall access (either through construction or upgrading rall spurs or Interrodal shipments(a)), or improve other deficiencies. The remalning 12 reactcrs were determined to be capable of handling only the smaller truck casks.

The percentage of plants that could receive and handle rail casks in the near-term ( $i . e_{.}$, assuming the current I imitations are not removed) would be reduced to $64 \%$. The primary reason for a plant to be judged incapable of handling rall casks in the near-term was a lack of rail access. The remalning $36 \%$ of the plants would be limited to truck shipments.

(a) See glossary. 
The modal fraction calculations Indlcated that up to $93 \%$ of the spent fuel accumulated by 1998 could be recelved at federal storage or disposal facil ities via rall (based on each plant's maximum capabilities). If the near-term cask handling capabilities are considered, the rall percentage is reduced to $62 \%$. However, most of this difference could potentially be shlpped offsite from reactors el ther via barge or heavy-haul truck intermodal shipments(a).

(a) See glossary. 


\section{ACKNOWLEDGEMENIS}

The authors wish to acknow ledge the assistance provided by a number of Individuals during the course of this study. First, we acknowledge the guidance, support, and technical revlew of the report provided by B. M. Cole of the Battelle Washington Office, G. C. Allen of the Transportation Technology Center (TTC) operated by Sandia Natlonal Laboratorjes, and J. W. Cashwell, also of the TTC. The editorial review prior to publication was contributed by C. A. Counts. Specjal thanks to K. J. Morgan for her secretarlal support. Finally, the authors wsh to express their appreclation to the many individuals from the varlous utilities who contributed information that led to the completeness of this report. 

CONIENTS

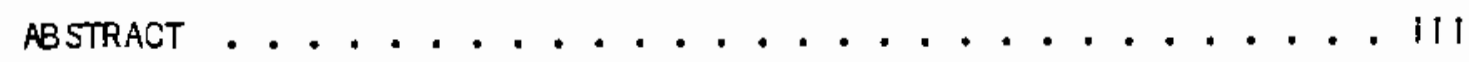

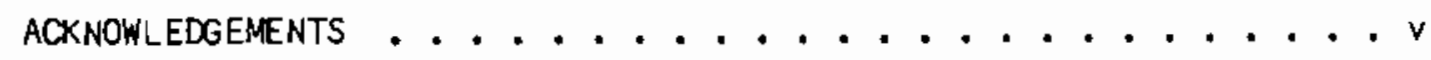

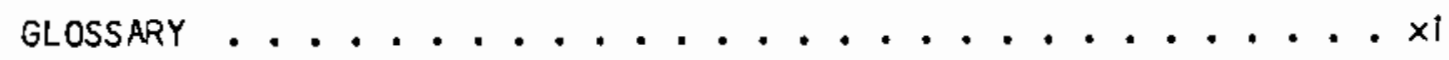

1.0 INTRODUCTION AND SUMMARY . . . . . . . . . . . 1.1

2.0 DBJECTIVES, APPROACH, AND STUDY BASES ........... 2.1

2.1 CBJeCtIVES. . . . . . . . . . . . . 2.1

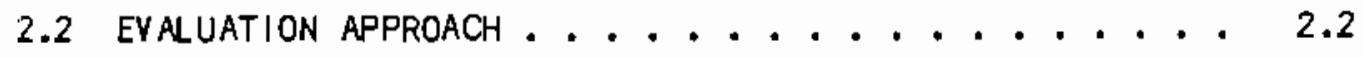

2.3 BASES ......................... 2.4

3.0 RESULTS OF THE CASK HAND ING CAPABIL ITY ASSESSNENT . . . 3.1

3.1 SHIPPING CASK HAND ING CAPABIL ITIES ....... 3.1

3.2 MODAL FRACTION ESTIMATES $\ldots \ldots \ldots \ldots . \ldots . \ldots$

REFERENCES ............................. Ref

APPENDIX A - DIRECTORY OF SPENT FUEL SHIPPING CASK HANDL ING

CAPAB IL ITIES AT CIVILIAN NUQ EAR POWER PLANTS . . A. A. 1

APPENDIX B - CHARACTERISTICS OF EXISTING SPENT FUEL SHIPPING CASKS .................. B. 


\section{IABLES}

1.1 Spent Fuel Shipping Cask Handing Capabilities of

Commerclal Nuclear Power Plants . . . . . . . . . 1.4

1.2 Summarles of In-pl ant and Current Cask Handling

Capabllitles.................. 1.7

3.1 Cverall Results of Cask Handling Capabil ity Assessments . 3.2

3.2 List of Plants That Are Not Provided With Rall Access . . 3.2

3.3 List of Plants Potentially Capable of Barge/Rail Intermodal Shipments............. 3.4

3.4 List of Reactors That Are Restricted to Legal-Welght Jruck Shipments ............. . 3.4

3.5 List of PIants That Could Handle the IF-300 Rall Cask But Not the NL1-10/24 .............. 3.6

3.6 Eesign-Basls Modal Fractions for Repository and MRS faclilities................ 3.7

B. 1 Selected Characteristics of Existing Spent Fuel Shipping Casks.................... B. 1 


\section{GLOSSARY/DEF INITIONS}

The followlng definitions are provided to clarify the terminology used In thls report so definitions of a number of terms could be removed from the text.

\author{
Barge Feasibility \\ Barge/Rail Intermodal \\ Feasibility
}

BWR

Cask Loading Pool

Commerclal Spent Fuel Management (CSFM) Program

Curren- Capabilities

DOE

DOE-EIA

Gross Vehicle Welght (GVW)
Indicates plant is located on a nav Igable waterway and could potentially ship spent fuel offsite directly by barge. Exlstence of warf or l anding slip is not necessary for plants to have barge feaslbility.

Indicates plants which could potentlally ship spent fuel offsite directly by barge in a rall cask. Requires that the plant has barge feasibility and Im-plant rall cask hand ing capabilities (see definition of In-plant capabilities)

Bolling water reactor.

Speclally designed and operated water-filled pool (or water basin) for lcading spent fuel assembl ies into transportation containers. The pool may be located in a corner of the spent fuel storage pool or it may be a separate structure connected to the storage pool by a water-fill led transfer canal.

The CSFM Program is a DOE-sponsored program at PN with the following objectives: 1) to encourage and expedite the implementation of exlsting and new spent fuel storage technologles; 2) to accelerate the avaiiablility of dry storage and rod consol idation technologies through I icensed cooperative cooperative demonstrations at reactor sites and unl icensed testing at federal facllities; and 3) to provide the planning for a federal capabillty to store up to $1900 \mathrm{MTU}$ of spent fuel for those utilities that the NRC determInes cannot reasonably provide increased at-reactor storage wen needed.

A term used in this evaluation to describe results. Indlcates which types of shipping casks could be handled at each plant wlthout major modifications of cask handling facllities. Includes consideration of technical specificatlons, derated crane capacities, and rall access onto the plant site.

U.S. Department of Energy.

DOE-Energy Information Administration.

The combined welght of the cargo, shipping container, tractor-traller or rallcar, and ancillary equipment. 
Heavy-Hau! Truck Shi pment

Heavy-Haul Truck/Ral I Intermodal Feasibility

Intermodal ShIpment

In-plant Capabilities

Legal-weight Truck (LWT) Shipment

Modal fraction

LWR

NRC

Overweight Truck

(OWT) Shipment
Shipment of overwelght or overdimension cargo that requires special equlpment. This type of shipment is often associated with intermodal shipments where a heavy rail cask Is transported by heavy-haul truck to a rall slding ( $f \circ$ plants that do not have rall access but wish to use rall casks) or barge slip.

Indicates plants whlch are not provided with rail access but which could potentially ship spent fuel offsite in a rall cask via heavy-haul truck shipment. A heavy-haul truck configuration would be used to move the cask to a rall siding where it would be removed from the truck and loaded onto a rallcar for subsequent movement (see also heavy-haul truck shipment)

A shipment that is performed using two or more transport modes. See barge/rall and heavy-haul truck/ intermodal feasibility.

A second term that was used to describe results. Indicates the types of shlpping casks that could be handled at each plant based on the maximum capabilities of cask handling facillties. Does not consider technical specitications, rall access, and derated crane capacitles because it was assumed that restrictions based on these parameters could potentlally be overcome.

A shipment that can be transported at a gross vehicle welght (GVW) that is no higher than the weight I imits beyond which states impose restrictions and require special permits (see al so legal-weight truck). The maximum GVW that has been imposed by most states is 80,000 lbs.

Fraction of spent fuel shipments that wlll be received at a Monitored Retrievable Storage facil ity or a geologic disposal repository by elther highway or rall transport modes.

Light water reactor.

U.S. Nuclear Regulatory Commission.

A shipment that is transported at a GVW in excess of legal welght I imitations imposed by states (see al so legal-welght truck). These shipments require special permits in each state and are subject to certain travel restrictions in some states (e.g., restricted to a certain time of day and time of year). 
PN

PWR

\author{
Rall Access \\ Spent Fuel Storage \\ PoOl \\ Technical Speci- \\ fications
}

Transport Mode

Utility Spent Fuel Data Verification Form
Paclf Ic Northwest Laboratory.

Pressurlzed water reactor.

The presence of a serviceable railspur that extends into a plant's cask handling facll ities.

Speclally designed and operated water pool (or water basin) for storing, cooling, shlelding, and maintalning spent (Irradiated) fuel assembl ies.

At nuclear power plants, technical specifications def ine plant variables, operating conditions, survell lance requirenents, and administrative controls wich are considered necessary to assure the health and safety of the public. Technical specifications are derlved trom analyses and evaluations of plant systems and components.

The manner or way in which spent fuel is transported; l. $\theta_{2}$, vla highway, rall, water, or alr. In thls country, spent fuel has been transported only via the highway and rall modes.

Questionnalres that were sent to nuclear utillities to gather spent fuel storage data. These forms provided the basis for a comprehensive, computerized data management system for LWR storage requlrements data. The system is operated by Pacif ic Northwest Laboratory (PNL) for the Department of Energy's Commerclal Spent Fuel Management Program. 

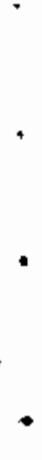


\subsection{INTRODUCTION AND SLIMMARY}

The Nucl ear Waste Policy Act of 1982 (NWPA) establ ishes the framework for the ultimate disposal of commerclally-generated, high-level radloactive wastes and spent nuclear fuel. The NWPA speclfles that the Department of Energy (DOE) will begin to accept these waste materials beginning In 1998 at a Monitored Retrievable Storage (MRS) facility or geologic disposal repository. These facllities will be part of the commerclal nuclear waste management system that is comprlsed of nuclear reactors, a transportation system, Inter im storage faclilities (If needed), and a disposal repository. The DOE will take title to spent nuclear fuel at commerclal nuclear power plant sites and transport the spent fuel to federally-owned or operated storage or disposal facllities. The DOE, wich wlll become a major shipper of radloactive wastes in the future, is currently imolved in long-range planning activitles to assure a safe and cost-effective transportation system.

Several DOE contractors are currently developing prel iminary designs of waste receiving and handling (R\&H) systems for MRS and repository facll itles. R\& $\mathrm{H}$ tacllities will be designed to receive waste shipments, unload wastes from transportation packagings, place the contal ners in overpacks (if necessary), and prepare the waste contai ners for emplacement in interim storage or disposal locations. The current design receipt rates for MRS and repository facilities are 3600 MTU and 3000 MTU of spent fuel, respectively, (or equivalent) per year. Based on approximate spent fuel shipping cask capacities of one MTU per truck shlpment and $10 \mathrm{MTU}$ per rail shipment, a range of 300 shipments per year to 3000 shipments per year of spent fuel will be required. The actual number of shipments per year will depend upon the mix of truck and rall shipments that will te recelved.

Fieal istic truck/rail modal fractions (defined as the fraction of spent fuel that 111 be recelved by truck and rall transport modes) and information on spent nuclear fuel shipping cask handling capabillities at reactor sites are needed to support MRS facll ity and repository design and environmental 
assessment activities. As a result, the Transportation Technology Center (TTC) at Sandla National Laboratories, DOE's prime contractor for transportation related research and development, directed this evaluation that was performed by the Pacif ic Northwest Laborafory (PN). The objective of this evaluation is to determine spent fuel shlpping cask handling capabllities and I imltations of commerclal nuclear power plants. This evaluation is an extension of a similar evaluation that was performed for the Commerclal Spent Fuel Management (CSFM) Program (Konzek and Daling 1984). The scope of the CSFM study, however, was I imited to evaluation of a select group of reactors that are nearing their maximum onsite spent fuel storage capacity. This evaluation includes all commerclal light water reactors (LWR's) currently operating and under construction.

The cask handling capabllity evaluations were facil itated by development of a computer ized data base that includes cask handing information for nuclear power plants that are elther operating or under construction. Both in-plant and ex-plant cask handling parameter data was collected ( in-plant refers to facilities and equipment with in the fences of the power plant site and ex-plant refers to facilities outslde of the fences). In addition, accessability of each nuclear power plant to roads, railways, and navigable waterways for barge shipping as well as capabilities and limitations of the cask handling equipment and facil ities are considered in this report.

The cask hand ing parameter data was collected from various sources. The first source was the data collected for the Commerclal Spent Fuel Management (CSFM) Program's spent fuel data base (DOE 1984). In previous years, the CSFM Program collected, but did not tabulate or verify, cask handling data that was provided by utilities. Thus, one task of this evaluation conslsted of reviewing and tabulating existing data. Information from the literature, whlch included plant-specific Prel iminary and Final Safety Analysis Reports (PSARs and FSARs), was also collected. The purpose of this revlew was to identify missing cask handling parameter data. A second task was performed to verify that the cask hand ing parameter data was accurate and to obtain missing data. This data verification task was performed by making telephone contacts with utility 
personnel knowledgeable about thelr plant's cask handing capabilities. The data was then entered Into a computerized data base to permit easy retrieval and sorting of data. After the cask handling parameter data was collected and verlfled, it was analyzed to determine whether each plant could handie legal welght truck (LWT), overwelght truck (OWT), or rall spent fuel shipping cask types (see glossary for definitions). This involved comparing the cask handing parameter data with the physical dimensions and loaded welghts of each type of cask.

The cask handling data base developed in this evaluation is contained in Appendix A. This appendix represents a "facll ities directory" of cask handling capabilities of commerclal nuclear power plants. It should be noted that the data presented in Appendix A represents each plant's current cask hand ing capabilities and 1 imitations. These data are subject to change in the future as utilities are faced with the need to perform spent fuel shipments. Since many utllities are not planning to ship spent fuel until the mid- to late- 1990 's, detal: ed cask-handl ing preparations and analyses have not been performed by such utilities. Therefore, they are uncertain about their full capabil ites and I imitations. For example, one plant was originally designed and constructed to recelve and handle a large rail cask. After the plant went into commercial operation, the rall spur serving the site was abandoned and paved over, I imiting the piant to truck shipments. However, it is still feasible for the plant to re-bu:Id the rail spur if they choose. Consequently, the facil ities directory should not be considered "final" nor should it be construed as an absolute indication that a utility will ship by a specific mode.

Table 1.1 presents the results of the cask handling capabil ity evaluations of commerclal nuclear power plants. The table shows which of the three types of shipp:ing casks can be recelved and handled at each plant. The table indicates in-plant handling capabilities, rall access Information, the feasibility 
TABLE 1.1. Spent Fuel Shipping Cask Handling Capabilities

\begin{tabular}{|c|c|c|c|c|c|c|c|c|c|}
\hline RLANT NAME (D) & $\begin{array}{l}\text { IN-FLA } \\
\text { LWT }\end{array}$ & $\begin{array}{l}\text { CAPAE } \\
\text { ONT }\end{array}$ & $\begin{array}{l}\text { ITIES } \\
\text { RAIL }\end{array}$ & $\begin{array}{l}\text { RAIL to } \\
\text { ACOESS }\end{array}$ & $\begin{array}{l}\text { DARGE (e) } \\
\text { FEASIBILITY }\end{array}$ & $\begin{array}{l}\text { INTERMOOAL(f) } \\
\text { FEAS IBILITY }\end{array}$ & $\begin{array}{l}\text { LRREN } \\
\text { LNT }\end{array}$ & OnT & RAIL \\
\hline $\begin{array}{l}\text { Arkansas Nuclear One - } 1 \text { (PMR)* } \\
\text { Arkansas Nuclear One - } 2 \text { (PMR)* } \\
\text { Arnold (BWR) } \\
\text { Beaver Vailey - } 1 \text { (PWR)* } \\
\text { Beaver Yall loy - } 2 \text { (PWR) }\end{array}$ & $\begin{array}{l}x \\
x \\
x \\
x \\
x\end{array}$ & $\begin{array}{l}x \\
x \\
x \\
x \\
x\end{array}$ & $\begin{array}{l}x \\
x \\
x \\
x \\
x\end{array}$ & $\begin{array}{l}x \\
x \\
x \\
x \\
x\end{array}$ & $\begin{array}{l}x \\
x\end{array}$ & & $\begin{array}{l}x \\
x \\
x \\
x \\
x\end{array}$ & $\begin{array}{l}x \\
x \\
x \\
x \\
x\end{array}$ & $\begin{array}{l}x \\
x \\
x \\
x \\
x\end{array}$ \\
\hline 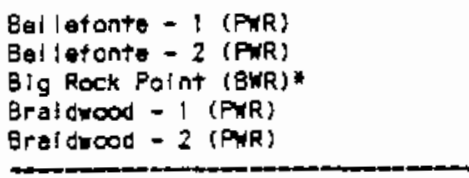 & $\begin{array}{l}x \\
x \\
x \\
x \\
x\end{array}$ & $\begin{array}{l}x \\
x \\
x \\
x\end{array}$ & $\begin{array}{l}x \\
x \\
x \\
x\end{array}$ & $\begin{array}{l}x \\
x \\
x \\
x \\
x\end{array}$ & $\begin{array}{l}x \\
x \\
x\end{array}$ & & $\begin{array}{l}x \\
x \\
x \\
x \\
x\end{array}$ & $\begin{array}{l}x \\
x \\
x \\
x\end{array}$ & $\begin{array}{l}x \\
x \\
x \\
x\end{array}$ \\
\hline $\begin{array}{l}\text { Browns Ferry - I (BWR) } \\
\text { Browns Ferry - } 2 \text { (BWR) } \\
\text { Brans Forry - 3 (BWR)* } \\
\text { Brunswick - 1 (BWR)* } \\
\text { Brunsw ick - } 2 \text { (BWR) }\end{array}$ & $\begin{array}{l}x \\
x \\
x \\
x \\
x\end{array}$ & $\begin{array}{l}x \\
x \\
x \\
x \\
x\end{array}$ & $\begin{array}{l}x \\
x \\
x \\
x \\
x\end{array}$ & $\begin{array}{l}x \\
x\end{array}$ & $\begin{array}{l}x \\
x \\
x\end{array}$ & $\begin{array}{l}x \\
x \\
x\end{array}$ & $\begin{array}{l}x \\
x \\
x \\
x \\
x\end{array}$ & $\begin{array}{l}x \\
x \\
x \\
x \\
x\end{array}$ & $\begin{array}{l}x \\
x\end{array}$ \\
\hline $\begin{array}{l}\text { Byron - } 1 \text { (PMR)* } \\
\text { Byron - } 2 \text { (PYR) } \\
\text { Callarey }-1 \text { (PWR)* } \\
\text { Calvert Cliffs - } 1 \text { (PWR)* } \\
\text { Calvert Clifts - } 2 \text { (PYR)* } \\
\end{array}$ & $\begin{array}{l}x \\
x \\
x \\
x \\
x\end{array}$ & $\begin{array}{l}x \\
x \\
x \\
x \\
x\end{array}$ & $\begin{array}{l}x \\
x \\
x \\
x \\
x\end{array}$ & $\begin{array}{l}x \\
x\end{array}$ & $\begin{array}{l}x \\
x \\
x \\
\end{array}$ & $\begin{array}{l}x \\
x \\
x \\
\end{array}$ & $\begin{array}{l}x \\
x \\
x \\
x \\
x\end{array}$ & $\begin{array}{l}x \\
x \\
x\end{array}$ & $\begin{array}{l}x \\
x\end{array}$ \\
\hline $\begin{array}{l}\text { Cataba - } 1 \text { (PMR) } \\
\text { Catamba - } 2 \text { (PWR) } \\
\text { Cl inton - } 1 \text { (BWR) } \\
\text { Comanche Peak - } \\
\text { Comanche Peak - } 2 \text { (PNR) }\end{array}$ & $\begin{array}{l}x \\
x \\
x \\
x \\
x\end{array}$ & $\begin{array}{l}x \\
x \\
x \\
x \\
x\end{array}$ & $\begin{array}{l}x \\
x \\
x \\
x \\
x\end{array}$ & $\begin{array}{l}x \\
x \\
x \\
x \\
x\end{array}$ & & & $\begin{array}{l}x \\
x \\
x \\
x \\
x\end{array}$ & $\begin{array}{l}x \\
x \\
x \\
x \\
x\end{array}$ & $\begin{array}{l}x \\
x \\
x \\
x \\
x\end{array}$ \\
\hline $\begin{array}{l}\text { Cooger (BWR)* } \\
\text { Crystal Rlver - } 3 \text { (PWR)* } \\
\text { O.C. Cook - I (RMR,* } \\
\text { D.C. Cook - } 2 \text { (PYR)* } \\
\text { Davis Besse (PYR)* }\end{array}$ & $\begin{array}{l}x \\
x \\
x \\
x \\
x\end{array}$ & $\begin{array}{l}x \\
x \\
x \\
x \\
x\end{array}$ & $\begin{array}{l}x \\
x \\
x \\
x \\
x\end{array}$ & $\begin{array}{l}x \\
x \\
x \\
x\end{array}$ & $\begin{array}{l}x \\
x \\
x \\
x \\
x\end{array}$ & $x$ & $\begin{array}{l}x \\
x \\
x \\
x \\
x\end{array}$ & $\begin{array}{l}x \\
x \\
x \\
x \\
x\end{array}$ & $\begin{array}{l}x \\
x \\
x \\
x\end{array}$ \\
\hline $\begin{array}{l}\text { Diablo Canyon - } 1 \text { (PWR)* } \\
\text { Diablo Canyon - } 2 \text { (PNR) } \\
\text { Oresden - I (BWR) } \\
\text { Oresden - } 2 \text { (EWP)* } \\
\text { Oresden - } 3 \text { (BWR)* }\end{array}$ & $\begin{array}{l}x \\
x \\
x \\
x \\
x\end{array}$ & $\begin{array}{l}x \\
x \\
x \\
x \\
x\end{array}$ & $\begin{array}{l}x \\
x \\
x \\
x\end{array}$ & $\begin{array}{l}x \\
x \\
x\end{array}$ & $\begin{array}{l}x \\
x \\
x \\
x \\
x\end{array}$ & $\begin{array}{l}x \\
x\end{array}$ & $\begin{array}{l}x \\
x \\
x \\
x \\
x\end{array}$ & $\begin{array}{l}x \\
x \\
x \\
x \\
x\end{array}$ & $\begin{array}{l}x \\
x\end{array}$ \\
\hline $\begin{array}{l}\text { Fariay - } 1 \text { (PWR)* } \\
\text { Fariey - } 2 \text { (PYR)* } \\
\text { Fermi - } 2 \text { (BWR) } \\
\text { Fitzpatrick (BWR)* } \\
\text { Fart Cal houn (PNR)* }\end{array}$ & $\begin{array}{l}x \\
x \\
x \\
x \\
x\end{array}$ & $\begin{array}{l}x \\
x \\
x \\
x \\
x\end{array}$ & $\begin{array}{l}x \\
x \\
x \\
x\end{array}$ & $\begin{array}{l}x \\
x \\
x \\
x\end{array}$ & $\begin{array}{l}x \\
x \\
x \\
x\end{array}$ & & $\begin{array}{l}x \\
x \\
x \\
x \\
x\end{array}$ & $\begin{array}{l}x \\
x \\
x \\
x \\
x\end{array}$ & $\begin{array}{l}x \\
x \\
x \\
x\end{array}$ \\
\hline $\begin{array}{l}\text { Ginne (PrR)* } \\
\text { Grand Gulf - } 1 \text { (BWR)* } \\
\text { Grand Gulf - } 2 \text { (BWR) } \\
\text { Haddan Nock (PWR)* } \\
\text { Harrls - I (PWR) }\end{array}$ & $\begin{array}{l}x \\
x \\
x \\
x \\
x\end{array}$ & $\begin{array}{l}x \\
x \\
x \\
x\end{array}$ & $\begin{array}{l}x \\
x \\
x \\
x\end{array}$ & $\begin{array}{l}x \\
x \\
x\end{array}$ & $\begin{array}{l}x \\
x \\
x\end{array}$ & & $\begin{array}{l}x \\
x \\
x \\
x \\
x\end{array}$ & $\begin{array}{l}x \\
x \\
x \\
x\end{array}$ & $\begin{array}{l}x \\
x \\
x\end{array}$ \\
\hline $\begin{array}{l}\text { Hatch - } 1 \text { (BWR)* } \\
\text { Hateh }-2 \text { (BWR) } \\
\text { Hope Croek (BWR) } \\
\text { Humboldt Bay (BWR) } \\
\text { Indlan Polnt - } 1 \text { (PWR) }\end{array}$ & $\begin{array}{l}x \\
x \\
x \\
x \\
x\end{array}$ & $\begin{array}{l}x \\
x \\
x \\
x \\
x\end{array}$ & $\begin{array}{l}x \\
x \\
x \\
x\end{array}$ & $\begin{array}{l}x \\
x \\
x\end{array}$ & $\begin{array}{l}x \\
x\end{array}$ & $x$ & $\begin{array}{l}x \\
x \\
x \\
x \\
x\end{array}$ & $\begin{array}{l}x \\
x \\
x \\
x\end{array}$ & $\begin{array}{l}x \\
x\end{array}$ \\
\hline
\end{tabular}




\section{TABLE 1.1. (Cont'd.)}

\begin{tabular}{|c|c|c|c|c|c|c|c|c|c|}
\hline RLANT NME (b) & $\begin{array}{l}\text { IN-R } \\
\text { LWT }\end{array}$ & $\begin{array}{l}\text { CNPE } \\
\text { ONT }\end{array}$ & $\begin{array}{l}\text { ITIES } \\
\text { RAIL }\end{array}$ & $\begin{array}{l}\text { RAIL } \text { id } \\
\text { ACCESS }\end{array}$ & $\begin{array}{l}\text { d) GARGE (e) } \\
\text { FEAS IBILITY }\end{array}$ & $\begin{array}{l}\text { INTERMOIIAL( } f)^{0} \\
\text { FEASIO IL!TY }\end{array}$ & $\begin{array}{l}\text { DNREENT } \\
\text { LHT }\end{array}$ & $\begin{array}{l}\text { CNFEI } \\
\text { ONT }\end{array}$ & $\operatorname{les}(g)$ \\
\hline 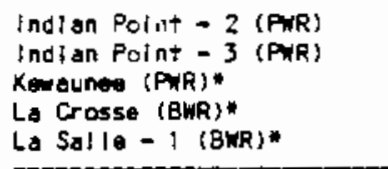 & $\begin{array}{l}x \\
x \\
x \\
x \\
x\end{array}$ & $\begin{array}{l}x \\
x \\
x\end{array}$ & $\begin{array}{l}x \\
x \\
x\end{array}$ & $\begin{array}{l}x \\
x\end{array}$ & $\begin{array}{l}x \\
x \\
x \\
x \\
x\end{array}$ & $x$ & $\begin{array}{l}x \\
x \\
x \\
x \\
x\end{array}$ & $\begin{array}{l}x \\
x\end{array}$ & $x$ \\
\hline $\begin{array}{l}\text { La Saile }=2 \text { (GWR) } \\
\text { Limerlek - } 1 \text { (BWR) } \\
\text { LImerlex }-2 \text { (BWR) } \\
\text { Maine Yankee (PWR) } \\
\text { Marble HIII - } 1 \text { (PWR) }\end{array}$ & $\begin{array}{l}x \\
x \\
x \\
x \\
x\end{array}$ & $\begin{array}{l}x \\
x \\
x \\
x\end{array}$ & $\begin{array}{l}x \\
x \\
x \\
x \\
x\end{array}$ & $\begin{array}{l}x \\
x \\
x \\
x \\
x\end{array}$ & $x$ & & $\begin{array}{l}x \\
x \\
x \\
x \\
x\end{array}$ & $\begin{array}{l}x \\
x \\
x \\
x\end{array}$ & $\begin{array}{l}x \\
x \\
x \\
x \\
x\end{array}$ \\
\hline 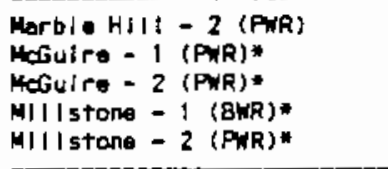 & $\begin{array}{l}x \\
x \\
x \\
x \\
x\end{array}$ & $\begin{array}{l}x \\
x \\
x \\
x\end{array}$ & $\begin{array}{l}x \\
x \\
x \\
x \\
x\end{array}$ & $\begin{array}{l}x \\
x \\
x \\
x \\
x\end{array}$ & $\frac{x}{x}$ & & $\begin{array}{l}x \\
x \\
x \\
x \\
x\end{array}$ & $\begin{array}{l}x \\
x \\
x \\
x\end{array}$ & $\begin{array}{l}x \\
x \\
x \\
x \\
x\end{array}$ \\
\hline 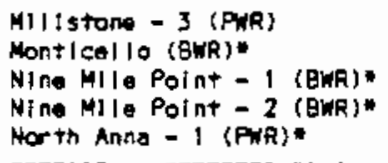 & $\begin{array}{l}x \\
x \\
x \\
x \\
x\end{array}$ & $\begin{array}{l}x \\
x \\
x \\
x \\
x\end{array}$ & $\begin{array}{l}x \\
x \\
x \\
x \\
x\end{array}$ & $\begin{array}{l}x \\
x \\
x \\
x \\
x\end{array}$ & $\begin{array}{l}x \\
x \\
x\end{array}$ & & $\begin{array}{l}x \\
x \\
x \\
x \\
x\end{array}$ & $\begin{array}{l}x \\
x \\
x \\
x \\
x\end{array}$ & $\begin{array}{l}x \\
x \\
x \\
x \\
x\end{array}$ \\
\hline $\begin{array}{l}\text { North Anne }-2 \text { (PWR) } \\
\text { Oconee }=1 \text { (PWR)* } \\
\text { Oconee }=2 \text { (PWR)* } \\
\text { Oconee }=3 \text { (PNR)* } \\
\text { Oyster Greek (BWR)* }\end{array}$ & $\begin{array}{l}x \\
x \\
x \\
x \\
x\end{array}$ & $\begin{array}{l}x \\
x \\
x \\
x \\
x\end{array}$ & $\begin{array}{l}x \\
x \\
x \\
x \\
x\end{array}$ & $x$ & $x$ & $\begin{array}{l}x \\
x \\
x \\
x\end{array}$ & $\begin{array}{l}x \\
x \\
x \\
x \\
x\end{array}$ & $\begin{array}{l}x \\
x \\
x\end{array}$ & $x$ \\
\hline $\begin{array}{l}\text { Pall sades (PWR)" } \\
\text { Palo Verde }-1 \text { (PWR) } \\
\text { Palo Verde }=2 \text { (PWR) } \\
\text { Palo Verde - } 3 \text { (PWR) } \\
\text { Peach Bottom - } 2 \text { (BWR)* }\end{array}$ & $\begin{array}{l}x \\
x \\
x \\
x \\
x\end{array}$ & $\begin{array}{l}x \\
x \\
x \\
x\end{array}$ & $\begin{array}{l}x \\
x \\
x \\
x\end{array}$ & $\begin{array}{l}x \\
x \\
x\end{array}$ & $x$ & $x$ & $\begin{array}{l}x \\
x \\
x \\
x \\
x\end{array}$ & $\begin{array}{l}x \\
x \\
x \\
x\end{array}$ & $\begin{array}{l}x \\
x \\
x\end{array}$ \\
\hline $\begin{array}{l}\text { Pesch Bottom }-3 \text { (BWR)* } \\
\text { Perry }=1 \text { (BWR) } \\
\text { Perry - } 2 \text { (BWR) } \\
\text { Pligr:m = } 1 \text { (BWR; } \\
\text { Polnt Bea:h - } 1 \text { (PWR)* }\end{array}$ & $\begin{array}{l}x \\
x \\
x \\
x \\
x\end{array}$ & $\begin{array}{l}x \\
x \\
x \\
x \\
x\end{array}$ & $\begin{array}{l}x \\
x \\
x \\
x\end{array}$ & $\begin{array}{l}x \\
x\end{array}$ & $\begin{array}{l}x \\
x \\
x \\
x\end{array}$ & $\begin{array}{l}x \\
x\end{array}$ & $\begin{array}{l}x \\
x \\
x \\
x \\
x\end{array}$ & $\begin{array}{l}x \\
x \\
x \\
x\end{array}$ & $\begin{array}{l}x \\
x\end{array}$ \\
\hline 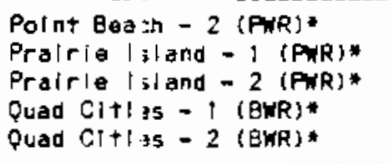 & $\begin{array}{l}x \\
x \\
x \\
x \\
x\end{array}$ & $\begin{array}{l}x \\
x \\
x \\
x \\
x\end{array}$ & $\begin{array}{l}x \\
x \\
x \\
x \\
x\end{array}$ & $\begin{array}{l}x \\
x \\
x \\
x\end{array}$ & $\begin{array}{l}x \\
x \\
x\end{array}$ & $x$ & $\begin{array}{l}x \\
x \\
x \\
x \\
x\end{array}$ & $\begin{array}{l}x \\
x \\
x \\
x\end{array}$ & $\begin{array}{l}x \\
x \\
x \\
x\end{array}$ \\
\hline 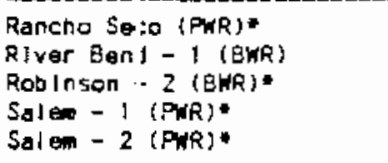 & $\begin{array}{l}x \\
x \\
x \\
x \\
x\end{array}$ & $\begin{array}{l}x \\
x \\
x \\
x \\
x\end{array}$ & $\begin{array}{l}x \\
x \\
x \\
x \\
x\end{array}$ & $\begin{array}{l}x \\
x \\
x\end{array}$ & $\begin{array}{l}x \\
x \\
x\end{array}$ & $\begin{array}{l}x \\
x\end{array}$ & $\begin{array}{l}x \\
x \\
x \\
x \\
x\end{array}$ & $\begin{array}{l}x \\
x \\
x \\
x \\
x\end{array}$ & $\begin{array}{l}x \\
x \\
x\end{array}$ \\
\hline $\begin{array}{l}\text { San Onotril - } 1 \text { (PWR) } \\
\text { San Onof ri - } 2 \text { (PWR) } \\
\text { San Onof ri: }-3 \text { (PNR) } \\
\text { Sedbrook - } 1 \text { (PWR) } \\
\text { Seabrook .. } 2 \text { (PWR) }\end{array}$ & $\begin{array}{l}x \\
x \\
x \\
x \\
x\end{array}$ & $\begin{array}{l}x \\
x \\
x \\
x \\
x\end{array}$ & $\begin{array}{l}x \\
x \\
x \\
x \\
x\end{array}$ & $\begin{array}{l}x \\
x\end{array}$ & & $\begin{array}{l}x \\
x \\
x\end{array}$ & $\begin{array}{l}x \\
x \\
x \\
x \\
x\end{array}$ & $\begin{array}{l}x \\
x \\
x \\
x \\
x\end{array}$ & $\begin{array}{l}x \\
x\end{array}$ \\
\hline
\end{tabular}




\section{TABLE 1.1. (Cont'd)}

\begin{tabular}{|c|c|c|c|c|c|c|c|c|c|}
\hline FLANT NANE (b) & $\begin{array}{l}\text { IN-PL } \\
\text { LET }\end{array}$ & $\begin{array}{l}\text { CAP: } \\
\text { Ont }\end{array}$ & $\begin{array}{l}\text { ITIES } \\
\text { RAIL }\end{array}$ & $\begin{array}{l}\text { RAIL (d } \\
\text { ACOESS }\end{array}$ & $\begin{array}{l}\text { BARGE (e) } \\
\text { FEASIBJLITY }\end{array}$ & $\begin{array}{l}\text { INTERMODAL }(f) \\
\text { FEAS IB IL ITY }\end{array}$ & $\begin{array}{l}\text { XRRENT } \\
\text { LWT }\end{array}$ & ONT & IES \\
\hline $\begin{array}{l}\text { Sequoyah - } 1 \text { (PNR)* } \\
\text { Sequoyeh }-2 \text { (PWR)* } \\
\text { Shoreham (BWR) } \\
\text { South Texas - } 1 \text { (PWR) } \\
\text { South Texos - } 2 \text { (PWR) }\end{array}$ & $\begin{array}{l}x \\
x \\
x \\
x \\
x\end{array}$ & $\begin{array}{l}x \\
x \\
x \\
x\end{array}$ & $\begin{array}{l}x \\
x \\
x \\
x\end{array}$ & $\begin{array}{l}x \\
x \\
x \\
x\end{array}$ & $\begin{array}{l}x \\
x \\
x\end{array}$ & & $\begin{array}{l}x \\
x \\
x \\
x \\
x\end{array}$ & $\begin{array}{l}x \\
x \\
x \\
x\end{array}$ & $\begin{array}{l}x \\
x \\
x \\
x\end{array}$ \\
\hline $\begin{array}{l}\text { St. Lucle }-1 \text { (PWR)* } \\
\text { St. Lucie - } 2 \text { (PWR)* } \\
\text { Summer (PWR) } \\
\text { Surry = } 1 \text { (PWR)* } \\
\text { Surry - } 2 \text { (PWR)* }\end{array}$ & $\begin{array}{l}x \\
x \\
x \\
x \\
x\end{array}$ & $\begin{array}{l}x \\
x \\
x \\
x \\
x\end{array}$ & $\begin{array}{l}x \\
x \\
x \\
x \\
x\end{array}$ & $x$ & $\begin{array}{l}x \\
x \\
x \\
x\end{array}$ & $\begin{array}{l}x \\
x \\
x \\
x\end{array}$ & $\begin{array}{l}x \\
x \\
x \\
x \\
x\end{array}$ & $\begin{array}{l}x \\
x \\
x\end{array}$ & $x$ \\
\hline 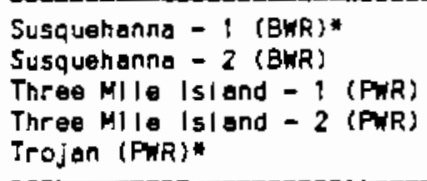 & $\begin{array}{l}x \\
x \\
x \\
x \\
x\end{array}$ & $\begin{array}{l}x \\
x \\
x \\
x \\
x\end{array}$ & $\begin{array}{l}x \\
x \\
x \\
x \\
x\end{array}$ & $\begin{array}{l}x \\
x \\
x \\
x\end{array}$ & $x$ & & $\begin{array}{l}x \\
x \\
x \\
x \\
x\end{array}$ & $\begin{array}{l}x \\
x \\
x \\
x \\
x\end{array}$ & $\begin{array}{l}x \\
x \\
x \\
x\end{array}$ \\
\hline $\begin{array}{l}\text { Turkey Point - } 3 \text { (PWR)* } \\
\text { Turkey Polnt }-4 \text { (PWR)* } \\
\text { Vermont Yankee (BWR)* } \\
\text { Yogtle }-1 \text { (PWR) } \\
\text { Yogtle }-2 \text { (PWR) }\end{array}$ & $\begin{array}{l}x \\
x \\
x \\
x \\
x\end{array}$ & $\begin{array}{l}x \\
x \\
x \\
x \\
x\end{array}$ & $\begin{array}{l}x \\
x \\
x \\
x \\
x\end{array}$ & $\begin{array}{l}x \\
x \\
x\end{array}$ & $\begin{array}{l}x \\
x \\
x \\
x\end{array}$ & $\begin{array}{l}x \\
x\end{array}$ & $\begin{array}{l}x \\
x \\
x \\
x \\
x\end{array}$ & $\begin{array}{l}x \\
x \\
x\end{array}$ & $\begin{array}{l}x \\
x \\
x\end{array}$ \\
\hline $\begin{array}{l}\text { WNP }=1 \text { (PNR) } \\
\text { WNP }-2 \text { (BWR)* } \\
\text { WNP }=3 \text { (PWR) } \\
\text { Waterford }-3 \text { (PWR) } \\
\text { Watts Bar - } 1 \text { (PNR) }\end{array}$ & $\begin{array}{l}x \\
x \\
x \\
x \\
x\end{array}$ & $\begin{array}{l}x \\
x \\
x \\
x \\
x\end{array}$ & $\begin{array}{l}x \\
x \\
x \\
x \\
x\end{array}$ & $\begin{array}{l}x \\
x \\
x \\
x\end{array}$ & $\begin{array}{l}x \\
x \\
x \\
x\end{array}$ & $x$ & $\begin{array}{l}x \\
x \\
x \\
x \\
x\end{array}$ & $\begin{array}{l}x \\
x \\
x \\
x \\
x\end{array}$ & $\begin{array}{l}x \\
x\end{array}$ \\
\hline $\begin{array}{l}\text { Watts Bar - } 2 \text { (PWR) } \\
\text { Holf Creek (PWR) } \\
\text { Yankee (PWR)* } \\
\text { Zlon - } 1 \text { (PWR)* } \\
\text { Zlon - } 2 \text { (PWR)* }\end{array}$ & $\begin{array}{l}x \\
x \\
x \\
x \\
x\end{array}$ & $\begin{array}{l}x \\
x \\
x \\
x\end{array}$ & $\begin{array}{l}x \\
x \\
x \\
x\end{array}$ & $\begin{array}{l}x \\
x \\
x \\
x\end{array}$ & $\begin{array}{l}x \\
x\end{array}$ & & $\begin{array}{l}x \\
x \\
x \\
x \\
x\end{array}$ & $\begin{array}{l}x \\
x \\
x \\
x\end{array}$ & $\begin{array}{l}x \\
x \\
x \\
x\end{array}$ \\
\hline $\begin{array}{l}\text { TOTALS } \\
\text { PWR'S } \\
\text { BWR'S } \\
\text { ALL PLANTS }\end{array}$ & $\begin{array}{r}86 \\
44 \\
130\end{array}$ & $\begin{array}{r}79 \\
49 \\
120\end{array}$ & $\begin{array}{r}79 \\
39 \\
118\end{array}$ & $\begin{array}{l}54 \\
34 \\
88\end{array}$ & $\begin{array}{l}47 \\
26 \\
73\end{array}$ & $\begin{array}{r}22 \\
9 \\
31\end{array}$ & $\begin{array}{r}86 \\
44 \\
130\end{array}$ & $\begin{array}{r}68 \\
41 \\
109\end{array}$ & $\begin{array}{l}52 \\
31 \\
83\end{array}$ \\
\hline
\end{tabular}

(a) LWT = Legal-welght truck; OWT = Overveight truck. See glossary for definitions of terms.

(b) AsterIsk (*) denotes operating plants

(c) " $x$ "Indicates in-plant handling conditions are such that casks of speclfled transport modes (LWT, OWT, or rail) could be hendled. Technical speciflcatlons are not consldered; 1.e., only the plants physlcal capablilties, as reported by utllities were const dered.

(d) " $x$ "indicates servicable rail spur extends lnto cask lading facllitles.

(e) " $X$ "1ndlcates plant is located on novigable waterway.

(f) Refers to the potentisl capability of loading a large rail or Ont cask at a plent that does not have rall access and then shippling the loeded cask by a short-distance heavy-haul truck mode to an off-site rall slding. Intermodal feasibility is not indlcated for plants with rall access.

(g) " $x$ "Indicates the cosk transport modes that can currently be received ond loaded; slngle mode shlpronts are consldered. Technlcal specification Ifmitatlons, if applicable, are al so cons I dered. 
of barge and intermodal shipping, and current capabilities. These terms were detined in the glossary. In-plant capabilities represent the maximum size of shlpping cask that could be handled by each plant's cask handing systems. Rail access (rall access was defined as a serviceable rail spur that extends into the cask looding facllities), technical speclfication limitations, and derated crane capac'tles were neglected. A utility's capability to place laded spent tuel shipp'ng casks onto a barge is based to a large extent on whether the plant is located on a navigable waterway. The column I abeled "Current Capabilities" represents an assessment of which types of casks can be recelved and handled at each plant based on current data. This is different than the "In-plant Capab "ities" column because the rall access information, technical specitication limitations, and derated crane capacities are considered. Intermodal shipping refers to loading a rail cask onto a speclal truck and transporting it short distances under a special permit to a location where it can be transferred onto a rallcar or barge. Intermodal shimments using the larger rail casks are judged to be feaslble if the in-plant conditions are such that rall casks can be handled but no rall access is provided. Appendix A shows the distance to the nearest rall siding for plants where no direct rail access exists. An overall summary of the in-plant and current cask handling capability evaluations is presented in Table 1.2. These results are discussed brlefly below.

[ABLE 1.2. Summary of In-plant and Current Cask Handling Capabillities Percentage of PI ants Capable of Handling Each Type of Cask (a)

\begin{tabular}{|c|c|c|c|c|c|c|}
\hline \multirow[b]{2}{*}{ Iype af Plant } & \multicolumn{3}{|c|}{ In-Plant Capab山lties } & \multicolumn{3}{|c|}{ current Capab لities } \\
\hline & LWT & Ont & Rall & LWT & OWT & Raل \\
\hline$P H R$ & 100 & 92 & 92 & 100 & 79 & 60 \\
\hline BWR & 100 & 93 & 89 & 100 & 93 & 70 \\
\hline --- & -- & - & -- & -- & --- & --- \\
\hline Al I Plants & 100 & 92 & 91 & 100 & 84 & 64 \\
\hline
\end{tabular}

(a) $\quad$-WT = legal-welght truck; OWT = overweight truck. See Table 1.1 for reactor-by-reactor 1 isting of cask handling capabllities. 


\section{Summary of ln-Plant Capabilities}

As shown in Tables 1.1 and 1.2, rail cask hand ing capabilities (in-plant) exist at 118 out of 130 reactors (91\%). Of the 86 pressurized water reactors (PWRs) and 44 bolling water reactors (BWRs), 79 (92\%) and 39 ( $89 \%$ ), respectively, could handle rail casks. Only seven PWR and flve BWR reactors (9\% of all plants) would be restrlcted to the use of truck casks (elther LWT or OWT) based on the in-plant cask handing capabilities. As shown in Table 1.1, most of the plants ( 88 out of 130 or $68 \%$ ) are currently provided with rail access. This Includes $63 \%$ of the PWRs and $77 \%$ of the BWRs. Barge shipments were determined to be feasible for a total of 73 plants which represents about $56 \%$ of the plants considered.

\section{Sumary of Current Capabilities}

Table 1.1 (current capabllities) shows that $83 \mathrm{plants}$ were determlned to be capable of receiving and hand ing rail casks. This represents $64 \%$ of all plants (see Table 1.2). Of the 86 PWRs, 52 (608) could ship spent fuel today using rall casks. Of the 44 BWR5, 31 were determIned to be capable of recelving and handling rall casks. This represents about $70 \%$ of the BWRs. As shown in Table $1.1,47$ plants were determined to be limited at this time to truck shipments. of those $47 \mathrm{plants}$ that are 1 imited to truck shipping, 21 are restricted to using LWT casks, including elghteen PWR and three BWR reactors. The remaining 26 plants could potentially use OWT casks.

\section{ModaL Fractions}

A final result of this evaluation concerns calculation of appropriate modal fractions. The modal fractions were calculated based on the imentory of spent nuclear fuel that is projected to have been discharged from commerclal reactors In 1998 (Heeb et al. 1985). It was determined that a total of 38,900 MTU of 
spent fuel wil have accumulated at the reactors I isted in Table 1.1 by 1998 (24,400 MTU of PWR spent fuel and 14,500 MTU of BWR spent fuel) based on the DOE Energy Information Administration's (E/A's) mIddle-case projection of Installed capacity and energy generation. The percentage of spent fuel that could potentially be shipped by rall was determined to be $93 \%$ if the maximum in-plant cask handling capabllities are assumed. If current capabllities are considered, the rall fraction is reduced to $62 \%$. however, most of this difference (which represents about 12,200 MTU of spent fuel) could be transported in rall casks using heavy-haul truck/rall intermodal shipments (see glossary for definition).

Barge feasibility exists at 73 plants. Of these 73 plants, 64 are capable of handling rall casks based on their in-plant capabilities. These $64 \mathrm{pl}$ ants (43 PWR and 21 BWR reactors) WIII have accumulated a total of about 20,600 MTU of spent fuel by 1998 (12,900 MTU of PWR and 7,700 MTU of BWR fuel). Thus, a total of $53 \%$ of the spent fuel accumulated by 1998 could potentially be shipped vla barge in rail casks. 


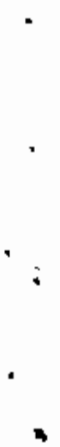

I 


\subsection{OBJECTIVES, APPROACH, AND STUDY BASES}

This section contains brlef descriptions of the study objectives, approach, and bases. Any assumptions made to facllitate the analyses are stated in the roport.

\subsection{OBJECTIVES}

The princlpal objectives of this evaluation were to 1 ) develop information on spent fuel shipping capablilities at U.S. nuclear power plants and 2) to define modal fractions for a repository or MRS tacillty that will recelve spent nuclear fuel from commerclal nuclear power stations. A data base of spent fuel shipping cask handling parameters for each commercial nuclear power plant was developed. The information in the data base was derived by collecting, verifying, and analyzing data that is relevant to light water reactors (LWRs) that are etther operating, shutdown, or under construction. The data base contains information about several reactors whose construction was subsequently cancelled. The fort St. Vrain plant was not included because it is not an LwR. A study similar to this one was pertormed under the Commerclal Spent Fuel Management (CSFM) Program but was 1 imited to 27 selected LWRs that utilities claim will have near-term spent fuel storage shortages (Konzek and Daling 1984). infornation collected in the CSFM study was used in this evaluation.

The assessment that was performed for each reactor included an eval uation of the in-plant spent fuel shipping cask handling facllities (such as the cask loadlig pool, cask handling crane, and the physical dimensions of entries into the sjent fuel storage area), as well as access routes (roadways and rall spurs) onto the reactor site and Into the cask hand ing area. An example of the latter might be a reactor that has the physical capabilities to IIft and handle a rall cask, but it is not provided with a rall spur that extends into the cask handling facllity. Thus, the scope of this evaluation Includes both in-plant cask nandling capabilities as well as the potential of delivering a cask to the faclility. Questions that were used to obtaln the desired information are listed bel ow. 
1. What are the capaclties of the cask handling crane and auxll lary hook (if any) ?

2. Are there floor lading l imits that could preclude setting dow a shipping cask welghing 80 tons? 100 tors ?

3. Does reactor have direct rail access? Name of servicing rall road? If no rall service is provided, what is approximate distance to nearest rail point?

4. Does the rall spur extend into the cask loading bay ?

5. Are there any welght or length limitations on the rall spur serving the site?

6. Are there any welght or length limitations on the road(s) serving the site (e.g., bridge restrictions)?

7. Is the reactor located on a navigable waterway?

8. What is the distance from the operating deck to the bottom of the crane holst when the holst is at its uppermost postition?

9. What is the distance from the bottom of the cask loading pool to the operating deck ?

10. What are the usable transverse dimensions of the cask loading pool ? Breadth, width ?

11. Are there any other conditions that would impede or limit cask handing (e.g., technical specifications, operating procedures, obstructions, sizes of doorways, protruding equipment, etc) ?

13. Have any spent fuel shipments been completed? Which cask(s) were used?

\subsection{EYALUATION APPROACH}

A three phase approach was used. Phase 1 consisted of a review and tabulation of existing data. PN maintalns a spent fuel data base, sponsored by the CSFM Program, that Includes information from Utility Spent Fuel Data Verification Form (see Glossary) that utllities completed annualiy in the past(a). Responses to the 1983 version of the torm, which included some of

(a) Starting In 1985, this information will be formally gathered by the DOE Energy Information Administration (E!A). 
the questions I isted above, was used as the initlal source of Information. Information was also collected from the open literature, Including plant-speciflc Safety Analysis Reports (SARs). The next step was to inventory and tabulate the data for each reactor. The inventory was conducted to identify missing data.

The second phase of this evaluation consisted of verifyling the data contained on the forms and collecting missing information. Efforts during this phase focused primarlly on tabul ating and performing qual ity assurance ( $Q A)$ check; and verifications of the accumul ated cask handling data. Thls effort invol red making telephone contacts with utility personnel that were knowledgeable about cask handling capabilitles at their plants. A form was devel oped to record the data collected during these telephone conversations. The end-product of this phase consisted primarily of a directory of cask handling capabilities and IImitations at each reactor. This "facllities directory" is presented in Appendlx A.

Thase 3 of this evaluation involved an assessment of each reactor's capability to handle three generic sizes of spent fuel shipping casks: legal-weight truck (LWT), overwelght truck (OWT), and rall (see Glossary). Physial dimensions of the exlsting spent fuel shlpping casks are presented in Appendix B. The physlcal dimensions of the three types of shlpping casks were compared with the handling capabllities and limitations of each reactor to estimate which types of shlpping casks can be handled at each plant. It should be noted that there are two sizes of existing spent fuel rall casks; 1) a I ight rall cask with a loaded welght of about $73 \mathrm{Mg}$ ( 80 tons), and 2) a heavy rail cask that weighs approximately $88 \mathrm{Mg}$ (97 tons) when loaded (see Appendix B). PI ants that are capable of handling the Iight rail cask but not the heavy rail cask were noted. The facll ities drectory (see Appendix A) contalns the results of these assessments. 
The results of the cask handling capabilities assesments are based on the best avallable data. A detalled analysls of each plant would be needed to ascertain their actual cask handling capabilities. In many cases, the utllities have never shipped spent fuel and are not planning shlpments in the near future. in these cases, the actual shipping cask handling capabilities are uncertain because the utility may not have qual if led the cask handling crane in accordance with the requlred control of heavy loads analyses (NRC 1979, NRC 1980, and NRC 1981a). Therefore, the results of this evaluation are subject to change as more and more utilities are faced with the need to ship spent fuel.

Modal fractions are the fractions of spent fuel that could be transported by LWT, OWT, or rail casks. Modal fractlons were calculated by adding together the amount of spent fuel that could potentially be shipped via each type of cask and then dividing by the total inventory of spent fuel at all reactors. The spent fuel inventory at each reactor in the year 1998, which is the year that the first repository is scheduled to begin receiving spent fuel, was used to calculate modal fractions. It is assumed that all reactors which can shlp by rall will do so; therefore, the rall modal fraction represents an upper l imit. The LHT and OWT modal fractions represent only the amount of spent fuel that is required to be shipped by these modes, based on cask handling l imitations at the reactors. Thus, LWT and OWT modal fractions represent lower I imits. This was done because plants that are capable of handing rall casks are also capable of handling LWT and OWT casks but the converse is not necessarily true. The actual modal fractions will depend upon the types of shipping casks that are selected by the reactors that have rall capabilities. Other considerations, which were not evaluated here, include economics, radiation exposure reduction, and carrler wll Ingness to transport spent fuel.

\subsection{BASES}

The major bases of this cask handling capabilities assessment are listed below. 
- Results are based on: 1) plant-specific responses provlded by utilities via DOE's 1983 Utility Spent Fuel Data Verification Form; 2) follow-up contacts with utllity personnel, and 3) applicable information contained in the open I iterature.

- Only the current cask handling capabilities of LWRs that are elther operating, shutdown, or under construction were evaluated (see Appendix A for detal(s).

- The existing commerclal spent fuel shipplng casks were used as the bases for the evaluations.

- Calculation of modal fractions were based on the projected inventorles of spent fuel at reactors in the year 1998. Reactor-by-reactor inventorles were obtalned from Heeb et al. (1985) which consists of utility-supplied data that has been modified to match the DOE-EIA projections for installed capacity and nuclear energy generation. The ElA mlddle-case projections were used. These projections were adjusted to subtract the spent fuel inventories at General Electric Co.'s Morris, Illinois tacility and at Nuclear Fuel Services, Inc.'s West Valley, New York facll ity because of uncertalnties in the final disposition of this tuel. Adjustments were also made to remove from the inventory the projected quantities of spent fuel from recently cancelled plants which were not included in the evaluation.

The cask hand ing parameter data was examined to determine the types of shipping casks that could be recelved and handled at each plant. The determinations of each plant's cask handling capabil ities were based on the criterla described below:

- In-plant cask handling capabilities represent the types of shipping casks that could be handled given the physlcal dimensions and original lifting sapabilities of each plant's cask handing systems. Technical specification I imitations and derated crane capabilities were not zonsidered in this case because some plants have not performed the analyses that are needed to determine their full capabilities. For example, some utilities have performed analyses only for a specific shipping cask. As a 
result, the utilities may not know their full range of cask usage alternatives. Thus, in-plant capabli lties represent the largest type of shjpping cask that could be handied given the original capabilities of the plant.

- Rall access refers to the accesslbility of the spent fuel handing facllities to rallroad service. The plants were judged to have rall access If a serviceable rall spur extended into cask loading bay. Plants that were originally provided with a rall spur that was subsequently abandoned or removed were judged not to have rall access.

- The feaslbility of barge transport is based primarily on whether or not a plant is located on a navigable waterway. The existence of barge docking facllities was noted in the facillties directory but was not required for a plant to be judged to have a barge-transport capability. Size restrictions of the barge facllities are al so In effect but these data were not avallable. Plants that have barge-transport feasibility and in-plant rall cask handing capabllities were judged to have the potentlal for barge/rall Intermodal shipments (see Glossary). Such plants would also be capab!e of barge/OWT intermodal shipments.

- Heavy-haul truck/rall intermodal feaslbllity (see Glossary) was evaluated for those reactors that did not have rall access. A plant was judged to have heavy-haul truck/rall intermodal capability if rall casks could be handled within the plant but could not be brought onto the site by rall. Such plants would also be capable of intermodal rail shlpments that use OWT casks.

- The final evaluation involved determining the current cask handing capabilities and I imitatlons of each plant. This determination was based on the best avallable cask handling data and included the rall access information, technical specification limitations, and derated crane capacities (If avallable). Therefore, the results of this evaluation provide a best estimate of the types of shipping casks that could be used at each plant if it were to ship spent fuel today. 


\subsection{RESULTS OF THE CASK HANDLUNG CAPABILUTY ASSESSMENI}

The rasults of this evaluation included: 1) a directory of cask handing parameter data for each nuclear power plant; 2) the results of the evaluation of each filant's cask hand ing capabilities and I imitations; and 3) an estimate of the modal fractions for which repository and MRS facllity receiving and handling systeris should be designed. The facllities directory is presented in Appendix A. The rest of this section presents the results of the cask handing capability evaluations (Section 3.1) and the modal fraction estimates (Section 3.2).

\subsection{SHIPPING CASK HANDLING CAPABILITIES}

The results of the evaluation of each plant's cask handling capabilities were tased on the criteria discussed in Section 2.3. Both in-plant cask handling capabilities and limitations as well as accessibility to highway, rall, and water modes of transport were considered. The evaluations were based on each plant's capability to recelve and load existing spent fuel shipping casks (see Appendix B). The results of the evaluations for each commercial nuclear power plant are described in Table 1.1 .

The overall results of the cask hand ing capability assessments are presented in Tabie 3.1. A total of 130 plants were examined in this study; 86 pressurized water reactors (PWRs) and 44 boiling water reactors (BWRs). None of these plants reported they could not recelve and handle a LWT cask. According to the in-plant cask handling parameter data (1.e., neglecting technical specitication I Imitations and derated crane capacities), ten plants could not handle OWT casks. Of these ten, seven were PWR and three were BWR reactors. Rail cask handling capabilities existed at 118 (91\%) of the plants. Of the 86 PWRs and 44 BWRs, 79 (92\%) and 39 (89\%), respectively, could potentially handle rall casks. A total of 88 plants $(68 \%)$ are currently provided with rall access. A list of the plants that are not provided with rail access is presented in Table 3.2. As shown, 32 of the 42 plants (76\%) without rall access could 
TABLE 3.1. Overall Results of Cask Handling Capability Assessments (a).

\begin{tabular}{|c|c|c|c|}
\hline Plant Tvpe & PWR & BiwR & A山Plants \\
\hline $\begin{array}{l}\text { Number of Plants } \\
\text { In=PI ant Capabli ities }\end{array}$ & 86 & 44 & 130 \\
\hline LHT & 86 & 44 & 130 \\
\hline ONT & $\begin{array}{l}79 \\
79\end{array}$ & $\begin{array}{l}4 i \\
39\end{array}$ & $\begin{array}{l}120 \\
118\end{array}$ \\
\hline Rall Access & 54 & 34 & 88 \\
\hline $\begin{array}{l}\text { Barge Feasloility } \\
\text { Intermodal Feaslbility }\end{array}$ & 47 & 26 & 73 \\
\hline Barge/Rall & 43 & $2 i$ & 64 \\
\hline $\begin{array}{l}\text { Heavy-haul Truck/Rall } \\
\text { Current Capabllities }\end{array}$ & 24 & 9 & 33 \\
\hline $\begin{array}{l}\text { LWT } \\
\text { OWT } \\
\text { RaII }\end{array}$ & $\begin{array}{l}86 \\
68 \\
52\end{array}$ & $\begin{array}{l}44 \\
41 \\
31\end{array}$ & $\begin{array}{r}130 \\
109 \\
83\end{array}$ \\
\hline
\end{tabular}

(a) See Table 1.1 for a plant-by-plant I isting of cask hand ing capabilities. LWT = legal-kelght truck, OwT = overweight truck. See glossary for detinltions of terms.

TABLE 3.2. List of Plants That are Not Provided With Rail Access

Plants Whout Rall Access (a)

- Browns Ferry 1,2,3 Pai isades(b)

- Callaway(b)

- Calvert Cliffs 1,2

- Crystal River $3(b),(c)$

- Diablo Canyon 1,2 Fort Cal houn G Inna

- Haddar Neck

- Hope Creek Indian Point 1,2,3

- Kenaunee

- Oconee $1,2,3$

- Oyster Creak(b)

Total: $42 \mathrm{Pl}$ ants (32 PWRs and 10 BHRs)

Plants whth RaU Access -- Cond Itlen of Track Unknown (d)
- Peach Bottón 2,3(b)

PII grim

- Point Beach $1,2^{(b)}$

- Salen 1,2

- San Onofre $1,2,3(b)$

Shor ehan

- St. LuCía 1,2

- Surry 1,2

- Trojan(b)

- Turkey polnt 3,4

- $W N P=2(c)$

Yankee (b)

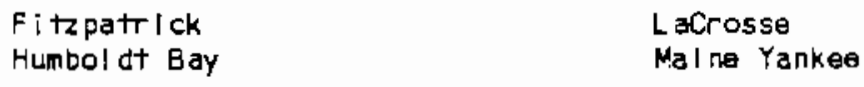

Total: 4 Pl ants (I PWR and 3 BWRs)

(a) Plants capable of heavy-haul truck/rail Intermodal shlpments are cenoted by a "o".

(b) These plamts were originally provided ith a rail spur wilch has subsequently been abandoned or is otherwise unsultable.

(c) Crystal River-3 and WNP-2 have a railspur onsite but the spur does not exteno into the cask handling facllities.

(d) Although the condition of the rallspur is unknown, these plants were judged to have rall access. 
potentially use the larger rall casks in a heavy-haul truck/rail intermodal shipment configuration. Pl ants that are located on navigable waterways (i.e., plants that have potential barge-shlpment capabilities) are listed in Table 3.3 . As shcwn, 73 plants $(56 \%)$ could potentially ship by barge. Of these 73 plants, 64 could potentially handle rall casks and thus are potentlally capable of using a barge/rail intermodal shipment configuration.

Lnder the "Current Capabilities" section of Table 3.1, all known current restrictions of each plant's cask handi ing systems (e.g., derated crane capacitles, technlcal specification I imitations, etc.) as well as rail access were considered in the evaluations. These columns represent the types of shipping casks that could be used if the utility was to ship spent fuel today. As shown, a total of 83 plants could potentially receive and handle rail casks (52 PWRs and 31 BWRs). This represents $64 \%$ of all plants (60\% of the PWRs and 708 of the BWRs) examined. The predom (nant reason that plants do not have rail cask receiving and handling capabllities is lack of rall access. Lack of rall access is shown for $32 \mathrm{PWR}(37 \%)$ and $10 \mathrm{BWR}$ reactors (23\%). This illustrates that $z$ higher percentage of the BwRs are provided with rail access than PWRs. Other l imitations are due to cask handling crane capacities and cask loading pool cimensions.

As shown in Tabie 3.1, ten pl ants are restricted to LWT casks based on their in-plant capabll ities and 21 are restricted to LWT based on thelr current capabilities. A list of these plants and the reasons for their l imitations are preserted in Table 3.4. As shown, the primary reason (besides lack of rall access) for a plant to be limited to LWT casks is a lack of adequate crane capacity. Of the $21 \mathrm{plants}$ I Imited to LWT shipments based on current capabilities, 15 are restricted because the lifting capabilities of their cask handling cranes (including consideration of technical speclfications) are not I arge enough to lift a rall cask. Seven plants are restricted to LWT casks because the dimensions of their cask loading pool are too small to accormodate a rall cask. Of these seven plants, three are also restricted because of the low capacity of their cask handling cranes. One utility indicated their plants have lengtr restrictions within the plant that preclude using anything but LWT casks. 
IABLE 3.3. List of PI ants Potent jally Capable of Barge/Rail Intermodal Shipments(a)

\begin{tabular}{|c|c|c|}
\hline $\begin{array}{l}\text { Beaver Valley } 1,2 \\
\text { Bell efonte 1,2 } \\
\text { Brows Ferry } 1,2,3 \\
\text { Callaw ay } 1 \\
\text { Calvert Cl ifts } 1,2 \\
\text { Cooper } \\
\text { Crystal River } 3 \\
\text { D. C. Cook } 1,2 \\
\text { Davis Besse } \\
\text { Diablo Canyon } 1,2 \\
\text { Oresden } 2,3 \\
\text { Farley } 1,2\end{array}$ & $\begin{array}{l}\text { Fitzpatr lck } \\
\text { Grand Gulf } 1,2 \\
\text { Haddar Neck } \\
\text { Hope Creek } \\
\text { Kew aunee } \\
\text { La Salle 1,2 } \\
\text { Maine Yankee } \\
\text { Millstone 1,2,3 } \\
\text { Nine Mile Pt. 1,2 } \\
\text { Oyster Creek } \\
\text { Perry 1,2 } \\
\text { Polnt Beach 1,2 }\end{array}$ & $\begin{array}{l}\text { Prairie } \mid \text { sl and } 1,2 \\
\text { River Bend } \\
\text { Salem } 1,2 \\
\text { Sequoyah } 1,2 \\
\text { St. Lucie } 1,2 \\
\text { Surry } 1,2 \\
\text { Trojan } \\
\text { Turkey P+. 3,4 } \\
\text { Vogtle } 1,2 \\
\text { WNP } 1,2,3 \\
\text { Watts Bar 1,2 } \\
\text { Zion } 1,2\end{array}$ \\
\hline
\end{tabular}

(a) These plants are capable of handling rall casks based on irrplant capabilities and are also located on a navigable waterway.

IABLE 3.4. List of Reactors That are Restricted to Legal-weight Truck Shipments

Ln-Plant Capabilities

Big Rock Polnt(a)(b)

Ginna(a)

Indian P+. 2,3(a)

LaCrosse(b)

Marble Hill $1,2(b)(d)$

Pal Isades $(a)(b)$

Shoreham (b)

Yankee (a) (b)

\section{Current Capabilities}

Big Rock Point(a)(b)

Calvert Cl iffs $1,2(a)$

GInna(a)

Indlan P+. $1,2,3(a)$

LaCrosse(b)

Marble Hill $1,2(b)(d)$

Oconee $1,2(\mathrm{c})$

Pal isades $(a)(b)$

Point Beach 1,2 (a)

Shor eham (b)

St. Lucie 1,2 (a)

Turkey P+. $3,4(a)$

Yankee(a)(b)

Total: $21 \mathrm{Plants}$

Total : $10 \mathrm{PI}$ ants

(a) Limitations are due to inadequate cask handl ing crane capability.

(b) Limitations are due to inadequate cask l oading pool dimensions.

(c) Limitations are due to lack of adequate clearances in airlocks, doorways, etc.

(d) Marble Hill 1 and 2 can handle small rall casks but not OWT casks because cask loading pool dimensions are too small to place the I arger diameter OWT casks in It. 
The data in Appendix A Indicates that only eight plants currently have technical specification I imitations that restrlct them to using LWT casks; Calvert $\mathrm{Cl}$ iffs 1 and 2, St. Lucie 1 and 2, Turkey Pt. 3 and 4, and Polnt Beach 1 and 2. As discussed previously, these plants may have these restrictions only because they performed analyses for a certain type of shippling cask. For example, a utility might have selected a speciflic type of cask and performed cask orop analyses using only the weights and dimensions of that particular cask. As a result, they are qual if ied to handle only that specif ic shipping cask even though they may be capable of handling a larger shipping cask. It shoulc be mentioned that many utilities have not performed spent fuel shipments and will not do so for many years. Consequently, they are not certain as to the derated capacities of thelr cask handling cranes. The data regarding cask handling crane restrictions for those utilities that have them are show in the "Comments" sections of Appendix A.

(ine further result concerns the particular rall cask chosen by a utility. The two existing choices are the $\mathrm{NLI-10/24}$ and the GE IF-300. It was found that since the NL1-10/24 is substantially larger than the IF-300, some plants are not capable of handling the $\mathrm{N} 1-10 / 24$ but are capable of handi Ing the IF-300. A I Ist of these plants is presented in Table 3.5. As shown, a total of $19 \mathrm{pl}$ ants are in thls category. These limitatlons are due primarily to the large outside diameter of the $\mathrm{N}:-10 / 24$, whlch restrlcts it from being placed in many cask loading pools. There are other plants that are provided with adequate ifting capabilities to handle the IF-300 but not the $\mathrm{NL}$-10/24. The results presented previously in Table 1.1 indlcate whether or not each plant can handle the If-300. Because of thls, it should be recognized that some plants I Isted in Table 1.1 are show as having rall cask handling capabilities but they are not capable of handling the N $1-10 / 24$ rall cask.

\subsection{MODAL ERACTION ESTIMATES}

"his section presents the estimated modal fractions that the designers of repos tory and MRS faclitities should consider. The following results are based on spent fuel discharge data for each commercial nuclear plant that was reported 
IABLE 3.5. List of Plants That Could Handle the IF-300 Rail

Cask But Not the N $1-10 / 24$.

\begin{tabular}{|c|c|}
\hline Plant Name & \\
\hline roldill pellile & Seasen for Lim \\
\hline Arnold (a) & Crane capacity \\
\hline Cooper & Crane capacity \\
\hline Diablo Canyon $1,2^{(a)}$ & Clearances on operating floor \\
\hline $\begin{array}{l}\text { Fort Calhoun (a) } \\
\text { Hooe Creek (a) }\end{array}$ & Pool dimensions, crane capacity \\
\hline Marble Hill 1,2 & Pool dimensions, crane capacity \\
\hline Mll I stone 1 & Pool dimensions \\
\hline Mont icello & Pool dimensions, crane capacity \\
\hline Oconee $1,2,3$ (a) & Pool dimensions \\
\hline Oyster Creek(a) & Pool dimensions \\
\hline Point Beach 1,2 (a) & Pool dimensions \\
\hline Three Mile |s| and 1,2 & Pool dimensions \\
\hline Vermont Yankee & Pool dimensions \\
\hline re & d with \\
\hline
\end{tabular}

by Heeb et al. (1985). This report contains utility-suppl ied spent fuel discharge data for each commerclal nuclear power plant that has been modified to match the DOE-ElA projections for installed capacity and energy generation under the ElA middle-case projections. The results of the modal fraction estimates were based on cumulative spent fuel discharges as of 1998, when the first repository is planned to begin recelving spent fuel. Cumulative discharges, which total 38,900 MJU of spent fuel in 1998, represent the inventories of spent fuel in each plant's spent fuel storage facllities. The quantities of spent fuel that are currently at General Electric Co.'s Morris, III inois, facil ity and Nuclear Fuel Services Co.'s West Valley, New York facllity were not included. In addition, Heeb et al. (1985) contalned spent fuel inventory data for some recently cancelled plants (Hartsville A1 and A2, Midland 1 and 2, and Yellow Creek 1 and 2) which were not included in this evaluation. As a result, the total spent fuel inventory used in this evaluation is slightly smaller than the inventory presented by Heeb et al. (1985). 
Modal fractions were estlmated by adding together the cumulative spent fuel discharges (given in units of MTU) for plants that could recelve and handle each type cf shipping cask. Separate spent fuel inventorles were calculated for reactcrs that could potentially recelve and handle rall casks (these plants would also be capable of handling OWT and LHT casks), OWT casks (whIch also incluces LWT cask handling capabllltles), and LWT casks only. The rail modal fraction is an estimate of the largest fraction of spent fuel that could potentlally be shipped by rall, whereas the LWT and OWT modal fractions represent lower limits. Thls is because it was assumed that all utilities wlll use the largest cask that their plants are capable of handling (see Section 2.2.). The results of these calculations are presented in Table 3.6 .

IABLE 3.6. Design-Basis Modal Fractions for Repository and MRS Facilities

Modal Fractions $(a),(b)$
In-PlantCapabHUties

\begin{tabular}{lllllll} 
PWRs & 0.06 & 0.01 & 0.93 & 0.21 & 0.21 & 0.58 \\
BWRs & 0.02 & 0.03 & 0.95 & 0.02 & 0.29 & 0.69 \\
\hline AlI PIants & $\overline{0.05}$ & $\overline{0.02}$ & $\overline{0.93}$ & $\overline{0.14}$ & $\overline{0.24}$ & $\overline{0.62}$
\end{tabular}

(a) Sipent fuel inventories in 1998 at the plants considered total approximately 38,900 MTU. Of this amount, 24,400 MTU will be PWR spent fuel and 14,500 wll be from BWRs. The values in the table represent the fractions of these inventories that could potentially be transported to MRS or repository facilities using LWT, OWT, and rail cask systems.

(b) $\quad$ LWT = Legal weight truck; OWT = Overwelght truck. See glossary. 
Calculations revealed that a total of approximately $38,900 \mathrm{MTU}$ of spent fuel wlll have been discharged by 1998 from the commercial nuclear power plants considered. Of this amount, 36,300 MTU, or about $93 \%$ could potentially be shipped by rall assuming the in-plant cask handling capabilities shown in Table 3.1. This means that only $7 \%$ of the spent fuel (about 2,600 MTU) would be required to be shipped by truck (OWT and LWT).

When current capabllitles and limitations are considered, the amount of spent fuel that could potentially be shipped by rail is reduced to about 24,100 MTU wich represents about $62 \%$ of the spent fuel inventory in 1998. The remaining $38 \%$ (or $14,800 \mathrm{MTU}$ ) would have to be shipped by LWT or OWT. This is about a $30 \%$ reduction of the quantity of spent fuel that could potentlally be transported in rail casks if in-plant capabillties are considered. This $30 \%$ reduction represents approximately 12,200 MTU of spent fuel. The additional 12,200 MTU could be shipped by truck. Alternatively, since the primary difference between in-plant and current cask handing capabilities was determined to be a lack of rall access, the bulk of this difference could be transported using intermodal shipments. In other words, a large percentage of the 12,200 MTU difference could potentially be shipped in rail casks, although the plants would have to use heavy-haul truck shipments to move the rail casks to and from the plants.

The overall result is that the repository and MRS facility designs should be based on modal fractions of approximately $62 \%$ to $93 \%$ rall shipping and $7 \%$ to $38 \%$ truck (I.e., LWT plus OWT) shipping. This is a best estimate of the range of modal fractions that are possible when assuming that those reactors that can ship by rall will do so. The minimum anount of spent fuel that must be transported by LWT was determined to be about 1,900 MTU (5\%) if in-plant handling capabilities are assumed. This value increases to about 5,500 MTU (14\%) If the current capabilities are consldered. It should be mentioned that these modal fractions are based only on cask handing capabilitles. The actual modal fractions may also be based on other factors that were not evaluated in thls report (e.g., economics, radiation exposures, rall carrler wllingness, etc.). 


\begin{abstract}
A final result concerns the potential capabilities of commerclal LWRs to transport spent fuel offsite directly by barge. It was determined that 73 plants could potentlaily ship using this transport mode based on their location on a navigable waterway. Of these 73 plants, 64 could use rail casks if their maximum In plant capabilities are assumed. The inventory of spent fuel at these $68 \mathrm{pl}$ ants is projected to total approximately 20,600 MTU in $1998-12,900$ MTU of FWF fuel and 7,700 MTU of BWR fuel. This inventory represents about 53\% of the tctal inventory of spent fuel that is projected to have accumulated by 1998 . Thus, a significant portion of the spent fuel could potentlally be shipped to MRS or repository facllities via barge.
\end{abstract}




\section{BEFERENCES}

Daling, P.M. 1984. Near-Term Commerclal Spent_Fuel Shipping_Cask Requirements. PN-5284. Paclif ic Nor thwest Laboratory, Richl and, Washington.

DOE. 1984. Spent Fuel Sterage Requirements, DOE/RL-84-1. U. S. Department of Energy, Richl and, Washlington.

Konzek, G.J. and P.M. Dal ing. 1984. Spent Fuel ShLpoing Cask Hand ing Capab Uty Assessment of 27 Selected Light Water Reactors. PN-5236. Pacif ic Northwest Laboratory, Richl and, Washington.

Heeb, C.M., R. A. Libby, and G.M. Holter. 1985. Reactor-Speclflc Spent Fuel Discharge Projections. PN-5396. Paclf Ic Northwest Laboratory, Richl and, Washington.

NRC. 1379. Single-Faلlure-Proof Cranes for Nuclear Power Plants. NUREG-0554. U.S. Nucl ear Regul atory Commission, WashIngton D.C.

NRC. 1380 . Control of Heavy Loads at Nuclear Power Plants. NUREG-0612. U.S. Nucl ear Regul atory Commission, Washington D.C.

NRC. 1381 a. Control of Heayy Loads. (Generic Letter 81-07). U. S. Nucl ear Regul atory Commission, Washington D.C.

NRC. 198 ib, Directory of Certificates of Compliance for Radioactive Materials Packages. NUREG-0383, Vol ume 2. U.S. Nucl ear Regul atory Commission, Washington D.C. 


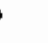




\section{APPENDIX A}

DIRECTQRY OF SPENT FUEL SHIPPING CASK HANDL ING CAPAB IL ITIES OF COMMERCIAL NUCLEAR_POHER PLANTS 
APPENDIX A

\section{QJRECTORY OF SPENI_FUEL_SH LPPING CASK HANDLING}

CAPAB ILITIES OF COMMERCIAL NUCLEAR POWER PLANTS

This appendix presents a data base of spent fuel shipping cask handing information for commerclal nuclear power plants. One page is presented with each plant's shipping cask handling data. The data are presented in alphabetical order accordling to the plant name. The cask handilng Information presented for each plant includes the types of casks that have been used in the past, freferred casks, sizes and capaclties of cask handling equipment and facilities, rall access information, and barge transport feasibillty. Also shown are the results of the assessments of each plant's near-term cask handing capability (i.e., assuming that current restrictions and limitations will not be remover).

Ir the following appendix, the term "Pool" Is used to describe two different items. "Pool" refers to the spent fuel storage pool when the parameter "Share Pool" is called out. It refers to the cask loading pool (which may or may not be separated from the spent fuel storage pool) when the parameters "Pool Depth", "Pool Width", and "Pool Length" are called out. 
PLANT NAME: A.N. O. -1

UTILITY: ARKANSAS POWER AND 2 IGHT COMPANY

NEAREST TOWN: RUSSELLVILLE, ARK

NRC DOCKET NUMBER: $50-313$

REACTOR TYPE : PWR

RATING:(a) $836 \mathrm{MWe}$

IN PLANT HANDL!NG PARAMETERS:

Share Pool:(b) NO

Preferred Cask: NOT YET CHOSEN

Cask Experience: NONE

Cask Crane Capacily, tons: 100

Crane Height, ft:(c) 29.0

Pool Depth, ft: (d) 43.0

Pool Width, ft: (d) 9.5

Pool Length, ft:(d) 10.2

COMMENTS: SEE COMMENTS, ANO-2

RAIL/BARGE ACCESS DATA:

Rajl Spur on Site: YES

Nearest railioad: MISSOUR! PACIFIC

Distance from Rall Spur to Cask bonding Ray: D milcs

Source of cooling water:

Barge Feasibility: NO

COMMENTS: SEE COMMENTS, ANO-2

CURRENT CASK HANDLING CAPABILITIES:

Legal Truck: YES

Overweight Truck: YES

Ra i 1: YES

(a) Spent Fuel Storage Requirements, DOE/RL-BA-1, May l9BA

(b) A lndicates common pool shared by two reactors.

B indicates pools connected by transfer canal

$C$ indicates pools connected by cask transfer.

(c) The distance from the operating deck to the bot tom of the crane hook at its uppermost position

(d) Refers to the respective usable dimension (i.e., length. width, or depth) of the cask loadung well. 
PLANT NAME: A.N.O.-2

UTILITY: ARKANSAS POWER AND LIGHT COMPANY

NEAREST TOWN: RUSSELLVILLE, ARK

NRC DOCKET NUMBER: $50-368$

REACTOR TYPE: PWR

RAT 1NG:(a) 858 MWe

IN PLANT HANDLING PARAMETERS:

Share Pool: (b) NO

Preferred Cask: NOT YET KNOWN

Cask Experience: NONE

Cask Crane Capacity, tons: 100

Crane Height, $f t:(c) 29.0$

Pool Depth, $f t:(d) 43.0$

Pool Width. ft: (d) 9.5

Pool Length, ft:(d) 10.2

COMMENTS: ONE POOL IS ON EACH SIDE OF REFUELING FLOOR. HATCH

IS $18^{\circ} X 12^{\circ}$. HAVEN'T LOOKED INTO CASK TYPES AND

HANDLING YET.

RAIL/BARGE ACCESS DATA:

Rail Spur on Site: YES

Nearest rall road: MISSOUR! PACIFIC

Distance from Rail Spur to Cask Loading Bay: 0 miles

Source of cooling water:

Barge Feasibility: NO

COMMENTS: RAILSPUR EXTENDS INTO TRAIN BAY UNDERNEATH REFUELINC FLOOR. LOCATED ON DARDANELLE RESERVOIR OFF THE ARKANISAS RIVER, BUT DON'T HAVE A DOCK.

CURRENT CASK HANDLING CAPABILITIES:

Legal Truck: YES

Overweight Truck: YES

RaIl: YES

(a) Spent fuel Storage Requirements, DOE/RL-84-1, May 1984

(b) A indicates common pool shared by two reactors.

B indicates poals connected by transfer canal.

C indicates pools connected by cask transfer.

(c) The distance from the operating deck to the bottam of the crane hook at its uppermost position.

(d) Refers to the respective usable dimension (i.e., length, wdth, or depth) of the cask loading wel!.

A. 3 
PLANT NAME: BEAVER VALLEY-1

UT I LITY: DUQUESNE LIGHT COMPANY

NEAREST TOWN: SHIPPINGPORT, PA

NRC DOCKET NUMBER: $50-334$

REACTOR TYPE : PWR

RATING: (a) B10 MWe

IN PLANT HANDLING PARAMETERS:

Share Pool: (b) NO

Preferred Cask:

Cask Experience:

Cask Crane Capacity, tons: 125

Crane Height, ft: (c) 27.1

Pool Depth, ft: (d) 41.5

Pool Width, $f t:(d) 12.0$

Pool Length, f $t:(d) 12.0$

COMMENTS: USE STANDARD $17 \times 17$ FUEL

RAIL/BARGE ACCESS DATA:

Rail Spur on 5ite: YES

Nearest rail road: CONRAIL

Distance from Rall Spur to Cask Loading Bay: 0 miles

Source of cooling water: OHIO RIVER

Barge Feasibility: YES

COMMENTS: HAVE BARGE SLIP, EXPECT THEY WOULD SHIP BY RAIL.

CURRENT CASK HANDLING CAPABILITIES:

Legal Truck: YES

Overweight Truck: YES

Ra i 1: YES

(a) Spent Fuel Storage Requitements, DOE/RL-B4-1, May 1984 .

(b) A indicates common pool shared by two reactors.

B indicates pools connected by transter canal.

C indicates pools connected by cask transfer.

(c) The distance from the operating deck to the bottom of the crane hook at its uppermost position.

(d) Refers to the respective usable dimension (1.e., length, widh, of depth) of the cask loading well

$$
\text { A. } 4
$$


PLANT NAME: BEAVER VALLEY- 2

UTI LITY: DUQUESNE LIGHT COMPANY

NEAREST TOWN: SHIPPINGPORT, PA

NRC DOCKET NUMBER: $50-412$

REACTOR TYPE: PWR

RATING: (a) $836 \mathrm{MWe}$

I N PLANT HANDLING PARAMETERS:

Share Pool:(b) NO

oreferred Cask:

vask Experjence:

Sask Crane Capact?y, tons: 125

Erane Height, $f t:(c) 27.1$

Pool Depth, ft:(d) 41.5

pool Width, ft: (d) 12.0

pool Length, f $t:(d) 12.0$

COMMENTS: SEE COMMENTS, BEAVER VALLEY I

RAIL/BARGE ACCESS DATA:

Rail Spur on Site: YES

Nearest rail road: CONRAIL

Distance from Rail Spur to Cask Loading Bay: 0 miles

Source of cooling water: OHIO RIVER

Barge Feasibility: YES

COMMENTS: SEE COMMENT5, BEAVER VALLEY $\cdot 1$

CURRENT CASK HANDLING CAPABILITIES:

Legal Truck: YES

Overweight Truck: YES

Rai l: YES

(a) Spent Fue! Storage Requirements, DOE/RL-84-1, May 1984 .

(b) A indicates common pool shared by two reactors.

a indicates pools connected by tiansfer canal

I lndicates pools connected by cask transter.

(c) The distance trom the operating deck to the bottom of the crane hook at its uppermost position.

(d) Refers to the respective usable dimension (i.e... length, width, or depth) of the cask loading we!l 
PLANT NAME : BELLEFONTE-1

UT ILITY: TENNESSEE VALLEY AUTHORITY

NEAREST TOWN : SCOTTSBORO,ALA

NRC DOCKET NUMBER: 50-43B

REACTOR TYPE: PWR

RAT ING: (a) $1213 \mathrm{MWe}$

IN PLANT HANDLING PARAMETERS:

Share Pool: (b) NO

Preferred Cask: NLI-10/24

Cask Experience:

Cask Crane Capacity, tons: 150

Crane Height. $f t:(c) 33$

Pool Depth, ft: (d) 43

Pool Width, ft: (d) 12

Pool Length, $f t:(d) 12$

COMMENTS: FACILITY IS DESIGNED FOR A CASK WEIGHING APPROXIAMATELY 100 TONS AND HAVING A CAPACITY OF 10 PWR FUEL ASSEMBLIES

USABLE DIMENSIONS OF CASK LOADING PIT ARE $18^{\circ}$ DEEP, $12, X 12$, AN INTERMEDIATE SHELF USED BY THE CASK. IS $12^{\prime}$ BY $99^{\prime}$ AND $17^{\prime}$ LONC.

RAIL/BARGE ACCESS DATA:

Rail Spur on Site: YES

Nearest rail road: SOUTHERN RAILWAY SYSTEM

Distance from Rail Spur to Cask Loading Bay: 0 miles

Source of cooling water: SEE COMMENTS

Barge Feasibility: YES

COMMENTS: BELLEFONTE PLANS ON SHIPPING BY TRAIN. BARGE IS POSSIBLE HOWEVER. COOLING WATER IS THE TENNESSE RIVER/CAUNTERSVILLE RESERVOIR.

CURRENT CASK HANDLING CAPABILITIES:

Legal Truck: YES

Overweight Truck: YES

Rai 1: YES

(a) Spent Fuel Storage Requirements, DOF/RL-84-1, May 1984.

(b) A indicates common pool shared by two reactors

B indicates pools connected by transfer canal

$C$ ind lcates pools connected by cask transfer.

(c) The distance from the operating dect to the bottom of the crane hook at its uppermost position

(d) Refers to the respective usable dimension (i.e.., length. width, or depth) of the cask loading well. 
PLANT NAME: BELLEFONTE-2

UTILITY: TENNESSEE VALLEY AUTHORITY

NEAREST TOWN : SCOTTSBORO,ALA

NRC DOCKET NUMBER: $50-439$

REACTOR TYPE : PWR

RATING: (a) $1213 \mathrm{MWe}$

IN PLANT HANDLING PARAMETERS:

Share Pool:(b) NO

Preferred Cask: NLI-10/24

Cask Experience:

Cask Crane Capacity, tons: 150

Crane Height, ft:(c) 33

Poo! Depth, ft: (d) 43

Pool Width, ft: (d) 12 .

Pool length, $f t:(d) 12$.

COMMENTS: SEE COMMENTS, BELLEFONTE-1

RAIL/BARGE ACCESS DATA:

Rail spur on Site: YES

Nearegt tailroad: SOUTHERN RAILWAY SYSTEM

Distance from Rail Spur to Cagk Loading Bay: 0 miles

source of cooling water: SEE COMMENTS BELLEFONTE-1

Barge Feasibility: YES

COMMENTS: SEE COMMENTS, BELLEFONTE-1

CURRENT CASK HANDLING CAPABILITIES :

Legal Truck: YES

Jverweight Truck: YES

Rajl: YES

(a) Spent Fuel Storage Requirements, DOE/RL-84-1, May 1984.

(b) A indicates common pool shared by two reactors.

B indicates pools connected by transfer canal

$C$ indicates pools connected by cask transfer.

(c) The distance from the operating deck to the bot tom of the crane hook at its uppermost position.

(d) Refers to the respective usable dimension fl.e., length, ridth, or depthl of the cask loading we!l.

A. 7 
PLANT NAME: BIG ROCK POINT

UTILITY: CONSUMERS POWER COMPANY

NEAREST TOWN : CHARLEVOIX, MJCH

NRC DOCKET NUMBER: 50-155

REACTOR TYPE: BWR

RATING: (a) $72 \mathrm{MWe}$

IN PLANT HANDLING PARAMETERS:

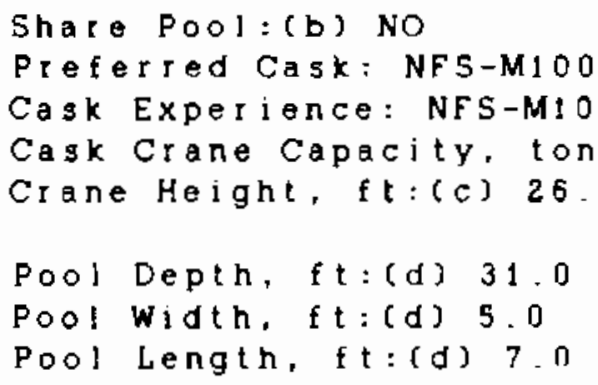

COMMENTS: CRANE CAPACITY OF 75 TONS DERATED TO 24 T AS RESULT OF DROP ANALYSIS, LENGTH OF CASK LIMITED BY NEED FOR ADEQUATE(ABOUT $B^{\circ}$ ) WATER COVERAGE AS FUEL, IS INSERTED INTO CASK. MAX LENGTH WITH THIS CRITERIA PROBABLY NOT GREATER THAN I $5^{\circ}$.

RAIL/BARGE ACCESS DATA:

Rail Spur on Site: NO

Nearest railroad: CHESAPEAKE AND OHIO

Distance from Rail Spur to Cask Loading Bay: 0 miles

Source of cooling water: LAKE MICHIGAN

Barge Feasibility: YES

COMMENTS: RAIL HAS NOT BEEN MAINTAINED IN LAST FEW YEARS. THERE ARE NO PROVISIONS FOR LOADING ANYTHING VIA LAKE MICHIGAN, AND TO LOAD BY WATER WOULD BE A VERY MAJOR UNDERTAKING.

CURRENT CASK HANDLING CAPABILITIES:

Legal Truck: YES

Overweight Truck: NO

Rai l: NO

(a) Spent Fuel Storage Requirements, DOE/RL-81-1, May 1984 .

(b) A indicates common pool shared by two reactors.

B indicates pools connected by transfer canal.

C indicates pools connected by cask transfer

(c) The djstance from the operating deck to the bottom of the crane hook at its uppermost position.

(d) Refers to the respective usable dimension (1.e., length, width, or depth) of the cask loading wel! 
PLANT NAME : BRAIDWOOD -1

UTILITY: COMMONWEALTH EDISON COMPANY

NEAREST TOWN : BRAIDWOOD, ILL

NRC DOSKET NUMEER: $50-456$

REACTOR TYPE: PWR

RAT INC (a) 1120 MWe

IN PLANT HANDLING PARAMETERS:

Share Pool: (b) A

Preferted Cask: NFS-4

Cask Experience:

Cask Crane Capacity, tons: 125

Crane Height, $f t:(c) 26.7$

Pool Depth, f $t:(d) 41$

Pool width, $f t:$ (d) 11

Fisol Length, $f t:(d) \quad 1 t$

COMMENTS: FLOOR LOADING LIMIT IS 500 LB. PER SQ. FT. UNITS

I\& 2 SHARE POOL, SIZE LIMITATION IS CASK LOADING AREA

RA1L/BARGE ACCESS DATA :

Rail Spur on Site: YES

Noarest rail road: ILLINOIS CFNTRAL GUI,F

Distance from Rall Spur to Cask Laading Bay: 0 miles

Surce of cooling water: MAN-MADE I,AKE

Barge Feasibility: NO

COMMENTS:

CURREN'T CASK HANDLING CAPABILITIES:

Legal Truck: YES

Overweight Truck: YES

Rail: YES

(a) Spent Fuel Storage Requirements, DOF/RL-84\%1, May 1984

(b) A indicates common pool shared by two reactors.

B Indicates pools connected by transter canat.

C indicates pools connected by cask transfer

(c) The distance from the operating deck to the bottom of the

crane hook at its uppermost position

(d) Refers to the respective usable dimension (1.e., length, width, or depth) of the cask loading weil

A. 9 
PLANT NAME : BRAIDWOOD -2

UTILITY : COMMONWEALTH EDISON COMPANY

NEAREST TOWN : BRAIDWOOD, ILL

NRC DOCKET NUMBER: 50-45?

REACTOR TYPE: PWR

RAT ING : (a) $1120 \mathrm{MWe}$

IN PLANT HANDLING PARAMETERS:

Share Pool: (b) A

Preferred Cask: NFS-4

Cask Experience:

Cask Crane Capacity, tons: 125

Crane Height, $f t:(c) 26.7$

Pool Depth, ft:(d) 41

Pool Width, it: (d) 11

Pool Length, $f t:(d)$ it

COMMENTS: SEE COMMENTS, BRAIDWOOD-1

RAIL/BARGE ACCESS DATA:

Rail Spur on Site: YES

Nearest railroad: ILLINOIS CENTRAL GULF

Distance from Rail Spur to Cask Loading Bay: 0 miles

Source of cooling water: MAN-MADE LAKE

Barge Feasibility: NO

COMMENTS :

CURRENT CASK HANDLING CAPABILITIES:

Legal Truck: YES

Overweight Truck: YES

Ra11: YES

(a) Spent Fuel Storage Requirements, DOE/RL-84-1, May 1984

(b) A indicates common pool shared by two reactars.

B indicates pools connected by transfer canal.

C indicates pools connected by cask transter.

(c) The distance from the operating deck to the bottom of the crane hook at its uppermost position.

(d) Refers to the respective usable dimension (1.e., length, widh, or depth) of the cask loading we!l. 
PLANT NAME: BROWNS FERRY-1

UTILITY: TENNESSEE VALLEY AUTHORITY

NEAREST TOWN : DECATUR, ALA

NRC DOCKET NUMBER： $50-259$

REACTOR TYPE: BWR

RATING: (a) 1067 MWe

IN PLANT HANDLING PARAMETERS:

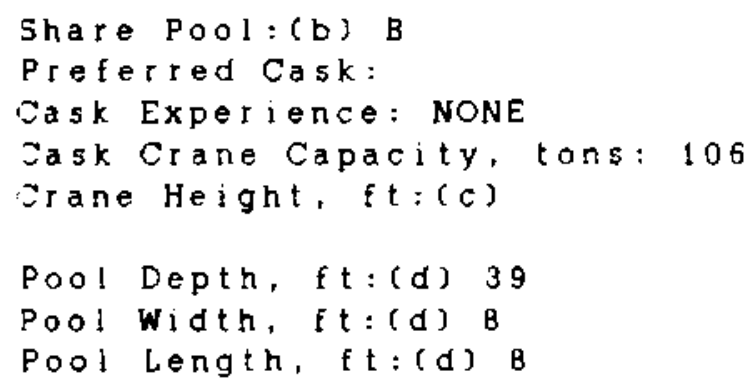

COMMENTS: 67 TON CASK HAS BEEN ANALYZED FOR USE AT BROWNS FERRY

\section{RAIL/BARGE ACCESS DATA:}

Rail Spur on Site: NO

Nearest railroad: LOUISVILLE AND NASHVILLE

Distance from Rail 5put to Cask Loading Bay: 7 miles

Source of cooling water: TENNESSEE RIVER

Barge Feasibility: YES

COMMENTS: BARGE FACILITY UNDER CONSTRUCTION

CURRENT CASK HANDLING CAPABILITIES:

Legal Truek: YES

Dverwejght Truck: YES

Ra i l : NO

\footnotetext{
(a) Spent Fuel Storage Requitements, DOF/RL-84-1, May 1984.

(b) A indlcates common pool shated by two reactors.

B indicates pools connected by transfer canal.

$\approx$ indicates pools connected by cask transfer.

(c) The distance from the operating deck to the bot om of the crane hook at its uppermost position.

(d) Refers to the respective usable dimension (1. e., length, width, or depth) of the cask loading well.
} 
PLANT NAME : BROWNS FERRY - 2

UTILITY: TENNESSEE VALLEY AUTHORITY

NEAREST TOWN: DECATUR, ALA

NRC DOCKET NUMBER: $50-260$

REACTOR TYPE : BWR

RAT ING : (a) 1067 MWe

IN PLANT HANDLING PARAMETERS:

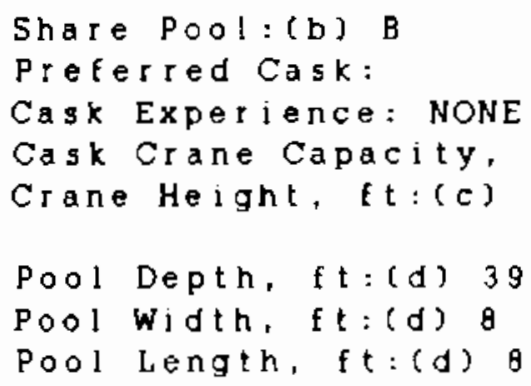

COMMENTS: SEE COMMENTS, BROWNS FERRY-1

RAIL/BARGE ACCESS DATA:

Rail Spur on Site: NO

Nearest railroad: LOUISVILLE AND NASHVILLE

Distance from Rail Spur to Cask Loading Bay: 7 miles Source of cooling water:

Barge Feasibility: YES

COMMENTS: SEE COMMENTS, BROWNS FERRY-1

CURRENT CASK HANDLING CAPABILITIES:

Legal Truck: YES

Overweight Truck: YES

Rail : NO

(a) Spent Fuel Storage Requirements, DOE/RL-84-1, MaY 1084

(b) A indicates common pool shared by two reactors.

B indicates pools connected by transfer canal

$C$ indicates pools connected by cask transfer

(c) The distance from the operating deck to the bottom of the crane hook at its uppermost position.

(d) Refers to the respective usable dimension (i.e., length, width, or depthl of the cask loading well 
PLANT NAME: BROWNS FERRY - 3

UT ! I ITY: TENNESSEE VALLEY AUTHORITY

NEAREST TOWN : DECATUR, ALA

NRC DOCKET NUMBER: $30-296$

REACTOR TYPE: BWR

RATING: (a) 1067 MWe

IN PLANT HANDLING PARAMETERS:

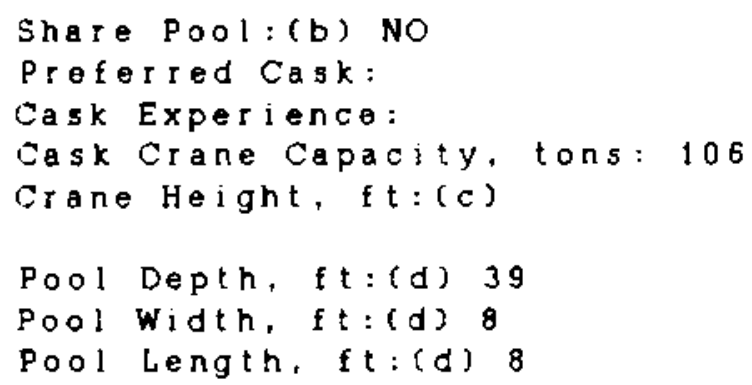

COMMENTS: SEE COMMENTS, BROWNS FERRY-1

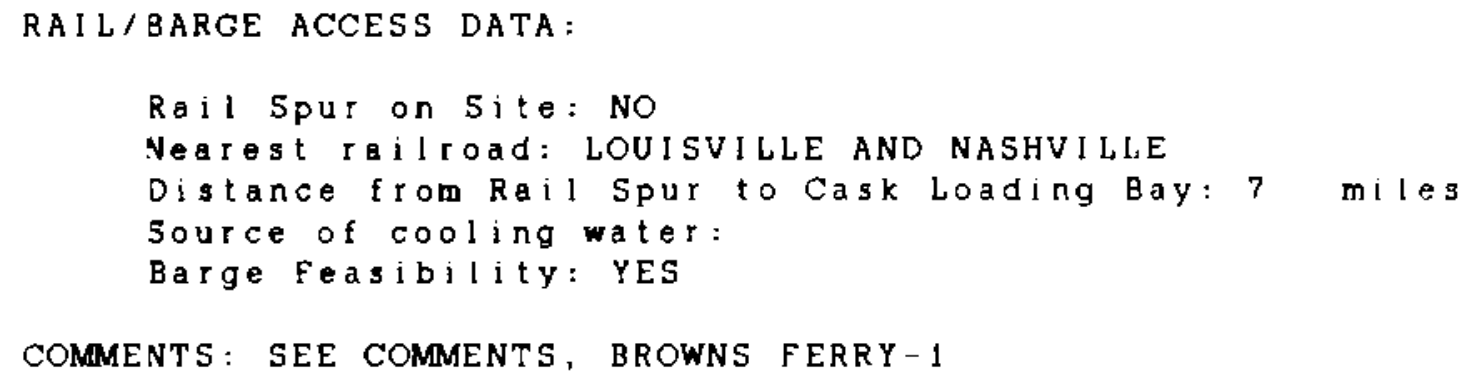

(a) Spent Fuel 5torage Requirements, DOE/RL-84-1, May 1984.

(b) 4 indicates common pool shared by two teactors.

B indicates pools connected by transfer canal $C$ indicates pools connected by cask transfer.

(c) The distance from the operating deck to the bottom of the crane hook at its uppermost position.

(d) Refers to the respective usable dimension (i.e., length, width, or depth) of the cask loading well.

\section{A. 13}


PLANT NAME : BRUNSWICK-1

UTILITY: CAROLINA POWER AND LIGHT CO

NEAREST TOWN : SOUTHPORT, NC

NRC DOCKET NUMBER； $50-324$

REACTOR TYPE : BWR

RATING : (a) 790 MWe

IN PLANT HANDLING PARAMETERS:

Share Pool:(b) NO

Preferred Cask: IF-300

Cask Experience: NAC1NFS4 NL!1/2

Cask Crane Capacity, tons: 125

Crane Height, f $t:(c) 28.2$

Pool Depth, ft: (d) 38.8

Pool width. ft: (d) 10.3

Pool Length, ft: $(d) 10.3$

COMMENTS: REACTOR BUIDDING AIRLOCK DIMENSIONS LIMIT RAIL CASK. CAR LENGTH TO 53.8 . .

\section{RAIL/BARGE ACCESS DATA:}

Rail Spur on Site: YES

Nearest railroad: SEABOARD COASTI,INE

Distance from Rail Spur to Cask Loading Bay: 0 miles

Source of cooling water: ATLANTIC OCEAN OUTFALL

Barge Feasibility: NO

COMMENTS :

CURRENT CASK HANDLING CAPABILITIES:

Legal Truek: YES

Overwelght Truck: YES

Rail: YES

(a) Spent Fuel Storage Requirements, DOE/RL-B4-1. May 1984

(b) A indicates common pool shared by two reactors.

B indicates pools connected by transfer canal.

C indicates pools connected by cask transfer.

(c) The distance from the operating deck to the bottom of the crane hook at 1 t 5 uppermost position.

(d) Refers to the respective usable dimension (1.e., length. width. or depthl of the cask loading well. 
PLANT NAME : BRUNSWICK-2

UTILITY: CAROLINA POWER AND LIGHT CO.

NEAREST TOWN: SOUTHPORT, NC

NRC DOCKET NUMBER: $50-325$

REACTOR TYPE: BWR

RAT 1NO: (a) $790 \mathrm{MWe}$

IN PLANT HANDLING PARAMETERS:

Share Pool: (b) NO

Preferred Cask: IF-300

Cask Experience: NAC1NFS4 NL!1/Z

Cask Crane Capacity, tons: 125

(rane Height, f $t:$ (c) 28.2

Pool Depth, ft: (d) 38.8

pool Width, ft: (d) 10.3

Pool length, $f t:(d) 10.3$

COMMENTS: REACTOR BUILDING AIRLOCK DIMENSIONS LIMIT RAIL CASK CAR LENGTH TO 53.8 '

RAIL/ JARGE ACCESS DATA:

Rail Spur on Site: YES

Nearest rail road: SEABOARD COASTLINE

Distance from Rail Spur to Cask Loading Bay: 0 miles jource of coo!ing water: ATLANTIC OCEAN OUTFALL

Barge Feasibility: NO

COMMENTS: SOUTHPORT, NC LOCATION.

CURRENT CASK HANDLING CAPABILITIES:

Jegal Truck: YES

Overweight Truck: YES

Rail: YES

(a) ipent Fuel storage Requirements, DOE/RL-84-1, May 1984.

(b) $A$ indicates common pool shared by two reactors.

3 indicates pools connected by transfer canal.

C indicates pools connected by cask transfer.

(c) The distance from the operating deck to the bottom of the crane hook at its uppermost position.

(d) Refers to the respective usable dimension (l.e., length, width, or depth) of the cask loading well.

A. 15 
PLANT NAME : BYRON-1

UTILITY: COMMONWEALTH EDISON COMPANY

NEAREST TOWN : BYRON, ILL

NRC DOCKET NUMBER: $50-454$

REACTOR TYPE : PWR

RATING : (a) 1120 MWe

IN PLANT HANDLING PARAMETERS:

Share Pool: (b) A

Preferred Cask: NFS-4

Cask Experience:

Cask Crane Capacity, lons: 125

Crane Height, $f t:(c)$

Pool Depth, ft:(d) 40

Pool Width, ft: (d) 9

Pool Length, $f t:(d) \quad 9$

COMMENT 5 :

RAIL/BARGE ACCESS DATA:

Rail Spur on Site: YES

Nearest rallioad: MILWAUKEE

Distance from Rail spur to Cask Loading Bay: 0 miles

Source of cooling water: ROCK RIVER

Barge Feasibility: NO

COMMENTS :

CURRENT CASK HANDLING CAPABILITIES:

Legal Truck: YES

Overweight Truck: YES

Rail: YES

(a) Spent Fuel Storage Requirements, DOE/RL-B4-1, Mav 1984

(b) A indicates common pool shared by two reactors.

$B$ indicates pools connected by transter canal.

$C$ indicates pools connected by cask transter.

(c) The distance from the operating deck to the bottom of the crane hook at its uppermost position.

(d) Refers to the respective usable dimension (t.e... length, width, or depth) of the cask loading well

A. 16 
PLANT NAME : BYRON-2

UTILITY: COMMONWEALTH EDISON COMPANY

NEAREST TOWN: BYRON, ILL

NRC DOCKET NUMBER: 50-453

REACTOR TYPE: PWR

RATING : (a) $1120 \mathrm{MWe}$

IN PLANT HANDLING PARAMETER S :

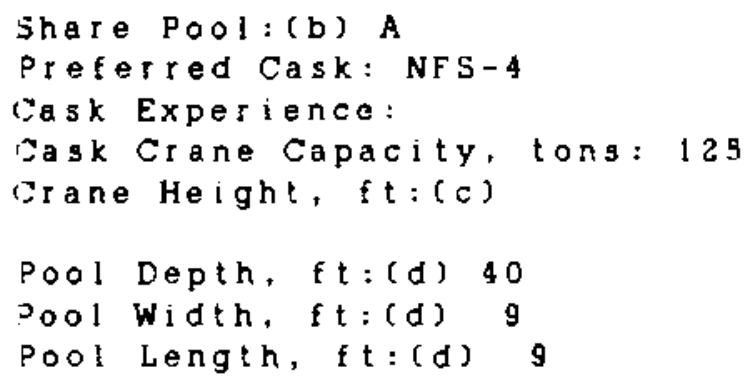

COMMENTS :

RAIL/ 3ARGE ACCESS DATA:

Rail Spur on 5 ite: YES

Nearest railroad: MILWAUKEE

Jistance from Rail Spur to Cask Loading Bay: 0 miles Jource of cooling water: ROCK RIVER

Barge Feasibility: NO

COMMENTS:

CURREVT CASK HANDLING CAPABILITIES:

Legal Truck: YES

Dverweight Truck: YES

Rail: YES

(a) Spent Fuel Storage Requirements, DOE/RL-g4-1, May 1984

(b) 4 indicates common pool shared by two reactors.

B indicates pools connected by transter canal.

indicates pools cannected by cask transfer.

(c) The distance from the operating deck to the bottom of the crane hook at its uppermost position.

(d) Refers to the respective usable dimension (i.e., length, widh, or depthJ of the cask loading well.

\section{A. 17}


PLANT NAME : CALLAWAY-1

UTILITY: UNION ELECTRIC COMPANY

NEAREST TOWN : FULTON, MO

NRC DOCKET NUMBER: $50-483$

REACTOR TYPE: PWR

RAT ING : (a) 1166 MWe

IN PLANT HANDLING PARAMETERS:

Share Pool: (b) NO

Preferred Cask: NONE SPECIFIED

Cask Experience:

Cask Crane Capacity, tons: 150

Crane Helght, $f t:(c) 31.3$

Pool Depth, ft: (d) 44.3

Paol Width, ft: (d) 16.0

Pool length, ft: (d) 38.0

COMMENTS: UPPER FLOOR LIMIT IS 1000 PSF

RAIL/BARGE ACCESS DATA:

Rail Spur on Site: NO

Nearest rail road: MISSOURI-KANSAS-TEXAS

Distance from Rail Spur to Cask Loading Bay: 0 milea

Source of cooling water: MISSOURI RIVER ( 5 MILES)

Barge Feasibility: YES

COMMENTS: TRUCK IS MOST PROBABLE, BOAT ACCESS IS POSSIBLE. TURBINES WERE LOADED FROM A BOAT. THERE USED TO BE TRAIN TRACKS UP TO THE PLANT, THESE HAVE SINCE BEEN TORN UP HOWEVER.

CURRENT CASK HANDLING CAPABILITIES:

Legal Truck: YES

Overweight Truck: YES

Ra 1 !: NO

(a) Spent Fuel Storage Requitements, DOE/RL-81-1, May 1984

(b) A indicates common pool shared by two reactors.

B indicates pools connected by transter canal

C indicates pools connected by cask transfer.

(c) The distance from the operating deck to the bottom of the crane hook at its uppermost position

(d) Refers to the respective usable dimension (i.e., length, width, or depth) of the cask loading we!l. 
PLANT NAME: CALVERT CLIFFS-1

UTILITY: BALTIMORE GAS AND ELECTRIC CO

NEAREST TOWN: LUSBY, MD

NRC DOCXET NUMBER: $50-317$

REACTOR TYPE: PWR

RATING: (a) $825 \mathrm{MWE}$

IN PLANT HANDLING PARAMETERS

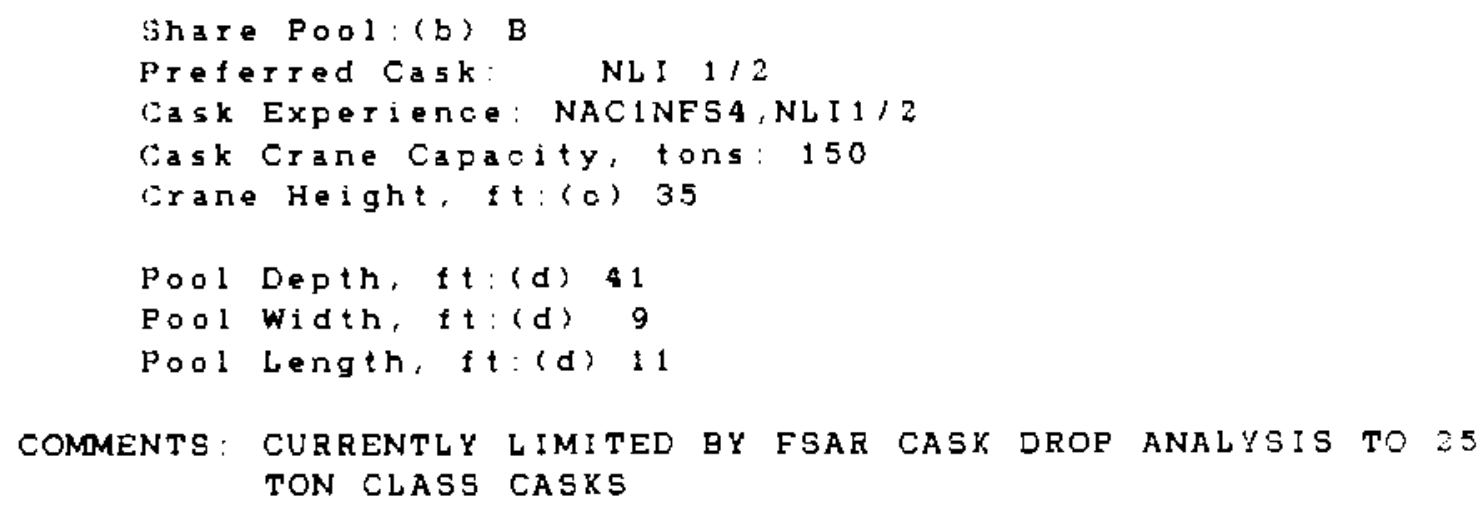

RAIL/BARGE ACCESS DATA:

Rail Spur on Site: NO

Nearest railroad: CONSOLIDATED RAIL

Distance from Rail Spur to Cask Loading Bay: 50 miles source of cooling water: CHESAPEAKE BAY

Barge Feasibility: YES

COMMENTS: PLANT IS ON A NAVIGABLE WATERWAY, WITH BARGE LANDING AT LUSBY, MD, RAIL SIDING - WALDORF, MD

CURRENT CASK HANDLING CAPABILITIES:

uegal Truck: YES

Jverweight Truck: NO

Rail: NO

\footnotetext{
(a) Spent Fuel Storage Requirements, DOE/RL-84-1, May 1984

(b) A indicates common pool shared by two reactors

a indicates pools connected by transter canal

$C$ indicates pools connected by cask transier

(c) The distance from the operating deck to the bottom of the crane hook at its uppermost position

(d) Refers to the respective usable dimension (i, e., length, width, or depth) of the cask loading well
} 
PLANT NAME: CALVERT CLIFFS-2

UTILITY: BALTIMORE GAS AND ELECTRIC CO

NEAREST TOWN : LUSBY, MD

NRC DOCXET NUMBER: $50-319$

REACTOR TYPE: PWR

RATING: (a) 825 MWe

IN PLANT HANDLING PARAMETERS:

Share Pool: (b) $\theta$

Preterred Cask: NLI i/2

Cask Experience: NAC1NFs4,NLI1/2

Cask Crane Capacity, tons: 150

Crane Height, ft: (e) 35

Pool Depth, it:(d) 41

Pool width, ft: (d) 9

Pool length, ft: (d) 11

COMMENTS: SEE COMMENTS, CALVERT CLIFFS-1

RAIL/BARGE ACCESS DATA:

Rail Spur on Site: NO

Nearest railroad: CONSOLIDATED RAIL

Distance from Rail Spur to Cask Loading Bay 50 milas

Source of cooling water: CHESAPEAKE BAY

Barge Feasibility: YES

COMMENTS: SEE COMMENTS, CALVERT CLIFFS-1

\section{CURRENT CASK HANDLING CAPABILITIES}

Legal Truck: YES

Overweight Truck: NO

Ra i 1 : No

(a) Spent Fuel Storage Requirements, DOE/RL-84-1, May 1984

(b) A indicates common pool shared by two reactors

B indicates pools connected by transter canal.

Cindicates pools connected by cask transfer

(c) The distance from the operating deck to the bottom of the crane hook at its uppermost position

(d) Refers to the respective usable dimension (i. e, length, width, or depth) of the cask loading well 
PLANT NAME: CATAWBA-1

UT ILITY : DUKE POWER COMPANY

NEAREST TOWN : CLOVER, SC

NRC DOCKET NUMBER: 50-413

REACTOR TYPE : PWR

RATING: (a) $1180 \mathrm{MWe}$

\section{IN PLANT HANDLING PARAMETERS:}

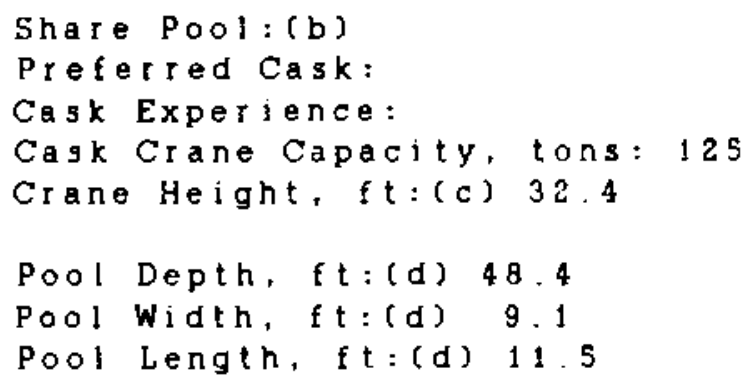

COMMENTS: PLANT CAN TAKE EITHER A TRUCK OR A RAIL CASK

RAIL/BARGE ACCESS DATA:

Rail Spur on Site: YES

Nearest rail! oad: SOUTHERN RAILWAY COMPANY

Distance from Rail Spur to Cask Loading Bay: 0 miles 5ource of cooling water: LAKE WYLIE

Jarge Feasibility: NO

COMMENTS :

CURRENT CASK HANDLING CAPABILITIES:

Legal Truek: YES

Overweight Truck: YES

२ail: YES

(a) Spent Fuel Storage Requirements, DOE/RL-84-1, May 1984 .

(b) A indicateg common pool shared by two reactors

3 indicates pools connected by transfer canal.

$c$ indicates pools connected by cask transfor.

(c) The distance from the operating deck to the bottom of the crane hook at its uppermost position.

(d) Refers to the respective usable dimension (i.e... length, width, or depthl of the cask loading we!l 
PLANT NAME : CATAWBA-2

UTILITY: DUKE POWER COMPANY

NEAREST TOWN: CLOVER, SC

NRC DOCKET NUMBER: $50-4 ! 4$

REACTOR TYPE : PWR

RATING: (a) $1180 \mathrm{MWe}$

IN PLANT HANDLING PARAMETERS:

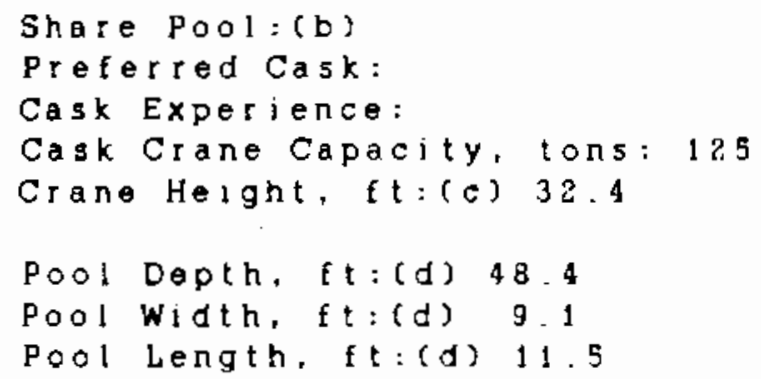

COMMENTS : SEE COMMENTS; CATAWBA-1

RAIL/BARGE ACCESS DATA:

Rai! Spur on Site: YES

Nearest $r$ a il road: SOUTHERN RA!LWAY CO

Distance from Rail $5 p u r$ to Cask Loading Bay: 0 miles

Source of cooling water: LAKE WYLIE

Barge Feasiblitity: NO

COMMENTS :

CURRENT CASK HANDLING CAPABILITIES :

Legal Truck: YES

Overweight Truck: YES

Rai I: YES

(a) Spent Fuel Storage Requirements, DOE/RL-84-1, May 1984 .

(b) A indicates common pool shared by two reactors

B indicates pools connected by transter canal.

C indicates pools connected by cask transfer.

(c) The distance from the operating deck to the bottom of the crane hook t its uppermost position.

(d) Refers to the respective usable dimension (i.e., length, width. or depth) of the cask loading well. 
PLANT NAME : CLINTON-I

UTILITY: ILLINOIS POWER COMPANY

NEAREST TOWN: CLINTON, I LL

NRC DOCKET NUMBER: 50-461

REACTOR TYPE : QWR

RATING:(a) $928 \mathrm{MWe}$

IN PLANT HANDLING PARAMETERS:

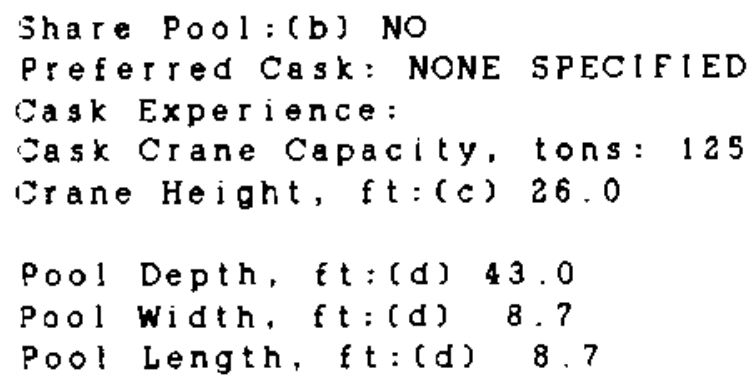

COMMENTS :

RAIL/BARGE ACCESS DATA:

Rail spur on Site: YES

Nearest railroad: ILLINOIS CENTRAL GULF RR

Distance from Rail Spur to Cask Loading Bay: 0 miles

Source of cooling water: ARTIFICIAL LAKE

Barge Feasibility: No

COMMENTS :

CURRENT CASK HANDLING CAPABILITIES:

Legal Truck: YES

Jverweight Truck: YES

Rail: YES

(a) Spent Fuel Storage Requirements, DOE/RL-84-1, May 1984

(b) A indicates common pool shared by two reactors.

B indicates pools connected by transfer canal.

C indicates pools connected by cask transfer.

(c) The distance from the operating deck to the bot om of the crane hook at its uppermost position.

(d) Refers to the respective usable dimension (i.e., length, width, or depth) of the cask loading well. 
PLANT NAME : COMANCHE PEAK-1

UTILITY: TEXAS UTILITIES GENERATING COMPANY

NEAREST TOWN : GLEN ROSE, TX

NRC DOCKET NUMBER: SO-445

REACTOR TYPE: PWR

RAT ING : (a) $1150 \mathrm{MWe}$

IN PLANT HANDLING PARAMETERS:

Share Pool: (b) B

Preferred Cask: $\mathrm{TN}-12$

Cask Experience:

Cask Crane Capacity, tons: 130

Crane Height, ft:(c) 30

Pool Depth, ft:(d) 47

Pool Width, ft: (d) 13

Poo! Length, ft: (d) 13

COMMENTS: FLOOR LOADING LIMIT IS 500 LB/SQ. FT

RAIL/BARGE ACCESS DATA :

Rail Spur on Site: YES

Nearest railroad: ATCHISON-TOPEKA-SANTA FE

Distance from Rail Spur to Cask Loading Bay: 0 miles

Source of cooling water: SQUAW CREEX RESERVOIR

Barge Feasibility: NO

COMMENTS :

CURRENT CASX HANDLING CAPABILITIES:

Legal Truck: YES

Overweight Truck: YES

Rail: YES

(a) Spent Fuel Storgge Requirements, DOE/RL-84-1, May 1984

(b) A indicates common pool shared by two reactors.

B indicateg pools connected by transfer canal.

$C$ indicates pools connected by cast transfer.

(c) The distance from the operating deck to the bottom of the crane hook at its uppermost position

(d) Refers to the respective usable dimension (i.e., length, widh, or depthj of the cask loading well. 
PLANT NAME : COMANCHE PEAK -2

UTILITY : TEXAS UTILITIES GENERATING COMPANY

NEAREST TOWN: GLEN ROSE, TX

NRC DOCKET NUMBER: $50-446$

REACTOR TYPE: PWR

RAT ING : (a) 1150 MWe

IN PLANT HANDLING PARAMETERS:

Share Pool : (b) B

Preferred Cask: TN-12

Cask Experience:

Cask Crane Capacity, tons: 130

Ciane Height, ft: (c) 30

Pool Depth, Et:(d) 47

Pool Width, $f t:(d) 13$

Pool Length, ft: (d) 13

COMMENTS : SEE COMMENTS; COMANCHE PEAK-1

RAIL/BARGE ACCESS DATA:

Rail Spur on Site: YES

Nearegt railroad: ATCHISON-TOPEXA-SANTE FE

Distance from Rail Spur to Cask Loading Bay: 0 miles

Source of cooling water:

Barge Feasibility: NO

COMMENTS :

CURRENT CASK HANDLING CAPABILITIES:

Legal Truck: YES

Jverweight Truck: YES

Ra 1 1: YES

(a) Spent Fuel Storage Requirements, DOE/RL-84-1, May 1984.

(b) A indicates common pool ghared by two reactors.

B indicates pools connected by transfer canal.

C indicates pools connected by cask transfer.

(c) The distance from the operating deck to the bottom of the crane hook at its uppermost position.

(d) Refers to the respective usable dimension (i.e.. length. width, or depth) of the cask loading we!l 
PLANT NAME: COOPER

UTILITY: NEBRASKA PUBLIC POWER DISTRICT

NEAREST TOWN : BROWNV ILLE, NEB

NRC DOCKET NUMBER: $50-298$

REACTOR TYPE : BWR

RATING: (a) $764 \mathrm{MWe}$

\section{IN PLANT HANDLING PARAMETERS:}

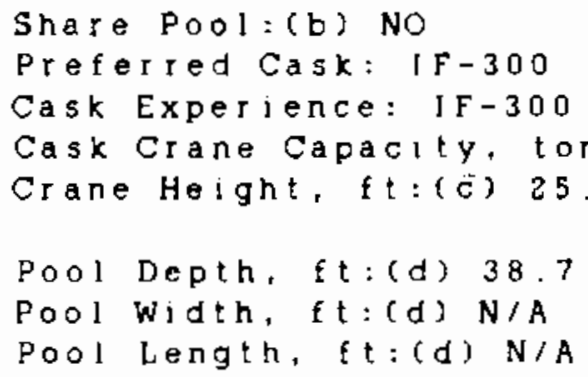

COMMENTS :

RA!L/BARGE ACCESS DATA:

Ra!l Spur on 5 jte: YES

Nearest railroad: BURLINGTON NORTHERN

Distance from Rall Spur to Cask Loading Bay: $n$ miles Source of cooling water: MISSOURI RIVER

Barge Feasibility: YES

COMMENTS :

CURRENT GASK HANDLING CAPABILITIES:

Legal Truck: YES

Overwejght Truck: YES

Ral l: YES

(a) Spent Fuel Storage Requirements, DOE'RL-84-1, May 1984

(b) A indicates common pool shared by two reactors.

B indjcates pools connected by transier canal.

C ind icates pools connected by cask tianster.

(c) The distance from the operating deck to the bottom of the crane hook at its uppermost position

(d) Refers to the respectlvo usable dimension ( t. c., length. width, or depth) of the cask loading well 
PLANT NAME : CRYSTAL RIVER-3

UTILITY: FLORIDA POWER CORPORATION

NEAREST TOWN : RED LEVEL, FL

NRC DOCKET NUMBER: $50-302$

REACTOR TYPE : PWR

RATING: ( a ) $836 \mathrm{MWe}$

I N PLANT HANDLING PARAMETER 5 :

Share Pool: (b) NO

Prefer red Cask: TRUCK

Cask Experience: NAC-1

Cask Crane Capacıty, tons: 120

Crane Height, ft: (c) 30.7

Poo! Depth, f t: (d) 43.7

Pool Width, ft: (d) 10.0

Pool Length, t $t:(d) 10.0$

COMMENTS: HATCHSIZE IS $35.7^{\prime} X 8^{\prime}, 6^{\prime}$. HAVE ONLY ONCE USED A CASK: SHIPPED AN NAC- 1 SINGLE ELEMENT CASK TO OCONEE, FLA IN 197?. MORE THAN LIKELY TO SH!P BY TRUCK.

RAIL/BARGE ACCESS DATA:

Rail Spur on Site: NO

Nearest railroad: SEABOARD COAST LINE

Distance from Rai! Spur to Cask Loading Bay: 1 miles

Source of cooling water: GULF OF MEXICO

Barge Feasibility: YES

COMMENT 5: HAVE A RAILSPUR, BUT IT IS NOT USEABLE RIGHT NOW; RAILSPUR GOES TO A DIFFERENT AREA ON THE NUCLEAR SITE AND IS LESS THAN I MILE AWAY. BARGE ACCESS IS NOT PRESENTLY USEABLE.

CURRENT CASK HANDLING CAPABILITIES :

Legal Truck: YES

Overweight Truck: YES

Raj ! : NO

(a) Spent Fuel Storage Requirements, DOf/RL-84-1, Mny J984

(b) A indicates common pool shared by two reactors.

B indicates pools connected by transfer canal.

$C$ indicates pools connected by cask transfer.

(c) The distance from the operating deck to the bottom of the crane hook at its uppermost position.

(d) Refers to the respective usable dimension ( 1. e... length, width, or depth) of the cask loading well 
PLANT NAME : D C COOK-1

UTILITY: INDIANA \& MICHIGAN ELECTRIC CO

NEAREST TOWN: BRIDGMAN, MICH

NRC DOCKET NUMBER: $50-31 \mathrm{~S}$

REACTOR TYPE : PWR

RAT ING : (a) 1044 MWe

IN PLANT HANDLING PARAMETERS:

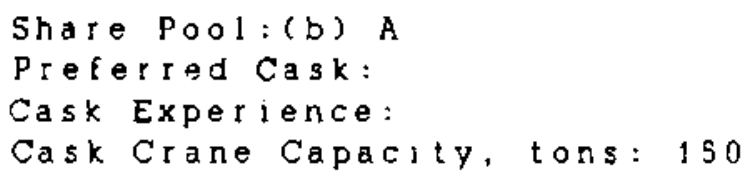

Share Pool: (b) A

Preferred Cask:

Cask Experience:

Cask Crane Capacity, tons: 150

Crane Height, f $t:$ (c) 35.0

Pool Depth, ft: (d) 44.3

Pool Width, ft: (d) 11.0

Pool Length, it: (d) 11.0

COMMENTS: PRESENT CRANE RATING IS 75 TONG, BUT FULL 150 TON

RATING EXPECTED AGAIN. ONE CORNER OF THE SPENT FUE\}, PIT IS SET ASIDE FOR CASK SET DOWN.

RAIL/BARGE ACCESS DATA:

Rail Spur on Site: YES

Nearest railroad: CHESAPEAKE \& OHIO

Distance from Rail Spur to Cask Loading Bay: 0 miles

Source of cooling water: LAKE M!CHIGAN

Barge Feasibility: YES

COMMENTS: NO BARGE FACILITIES AT PRESENT. OVERWEIGHT TRUCK

AS WELL AS RAIL CAR COULD GET INTO BAY AREA

CURRENT CASK HANDLING CAPABILITIES:

Legal Truck: YES

Overweight Truck: YES

Rai 1: YES

(a) Spent Fuel Storage Requirements, DoE/RL-84-1, May 1984

(b) A ind lcates common pool shared by two reactors.

B indicates pools connected by transfer canal.

C indicates pools connected by cask transter.

(c) The distance from the operating deck to the bottom of the crane hook at its uppermost position

(d) Refers to the respective usable dimension (l.e., length. width, or depth) of the cask loading well. 
PLANT NAME : D C COOK-2

UTILITY: INDIANA \& MICHIGAN ELECTRIC CO.

NEAREST TOWN : BRIDGMAN, MICH

NRC DOCKET NUMBER: $50-316$

REACTOR TYPE : PWR

RATING: (a) $1082 \mathrm{MWe}$

IN PLANT HANDLING PARAMETERS:

Share Pool:(b) A

Preferred Cask:

Cask Experience:

Cask Crane Capacity, tons: 150

Crane Height, ft: (c) 35.0

Pool Depth, ft:(d) 44.3

Pool Width, ft: (d) 11,0

pool kength. ft: (d) 11.0

COMMENTS: SEE COMMENTS; COOK-1

RAIL/BARGE ACCESS DATA:

Rai I Spur on Site: YES

Nearest rajlroad: CHESAPEAKE \& OHIO

Distance from Rall Spur to Cask Loading Bay: 0 miles Source of cooling water:

Barge Feasibility: NO

COMMENTS: SEE COMMENTS; COOK-1

CURRENT CASK HANDLING CAPABILITIES:

Legal Truck: YES

Dverweight Truck: YES

Rail: YES

(a) Jpent Fuel storage Requirements, DOE/RL-84-1, May 1984.

(b) A indicates common pool shared by two reactors

$B$ indicates pools connected by transfer canal.

C indicates pools connected by cask transfer.

(c) The distance from the operating deck to the bottom of the crane hook at its uppermost position.

(d) Refers to the respective usable dimension (i.e., length, width, or depth) of the cask loading well. 
PLANT NAME : DAVIS-BESSE- 1

UTILITY: TOLEDO EDISON COMPANY

NEAREST TOWN : OAK HARBOR, OHIO

NRC DOCKET NUMBER: $50-346$

REACTOR TYPE : PWR

RATING : (a) $8 ? 4 \mathrm{MWe}$

IN PLANT HANDLING PARAMETERS:

Share Pool: (b) NO

Preferred Cask:

Cask Experience:

Cask Crane Capacity, tons: 125

Crane Height, $\mathrm{ft}:(c)$

Pool Depth, ft:(d) 42

Poo! Width, ft: (d) 10

Pool Length, $f t:(d) 10$

COMMENTS :

RAIL/BARGE ACCESS DATA:

Rail Spur on Site: YES

Nearest railroad: NORFOLK AND WESTERN

Distance from Rail 5 pur to Cask Loading Bay: 0 miles

Source of cooling water: LAKE ERIE

Barge Feasibility: YEs

COMMENTS :

CURRENT CASK HANDLING CAPABILITIES:

Legal Truck: YES

Overweight Truck: YES

Rail: YES

(a) Spent Fuel Storage Requirements, DOE/RL-84-1, May 1984.

(b) A indicates comson pool shared by two reactors.

$B$ indicates pools connected by transfer canal.

$C$ indicates pools connected by cask transfer.

(c) The distance from the operating deck to the bottom of the crane hook at its uppermost position.

(d) Refers to the respective usable dimenston (1,e., length, width, or depth) of the cask loading well. 
PLANT NAME: DIABLO CANYON-1

UTILITY: PACIFIC GAS AND ELECTRIC CO.

NEAREST TOWN: AVILA BEACH, CA

NRC DOCKET NUMBER: 50-275

REACTOR TYPE: PWR

RATING : (a) $1085 \mathrm{MWE}$

IN PLANT HANDLING PARAMETERS :

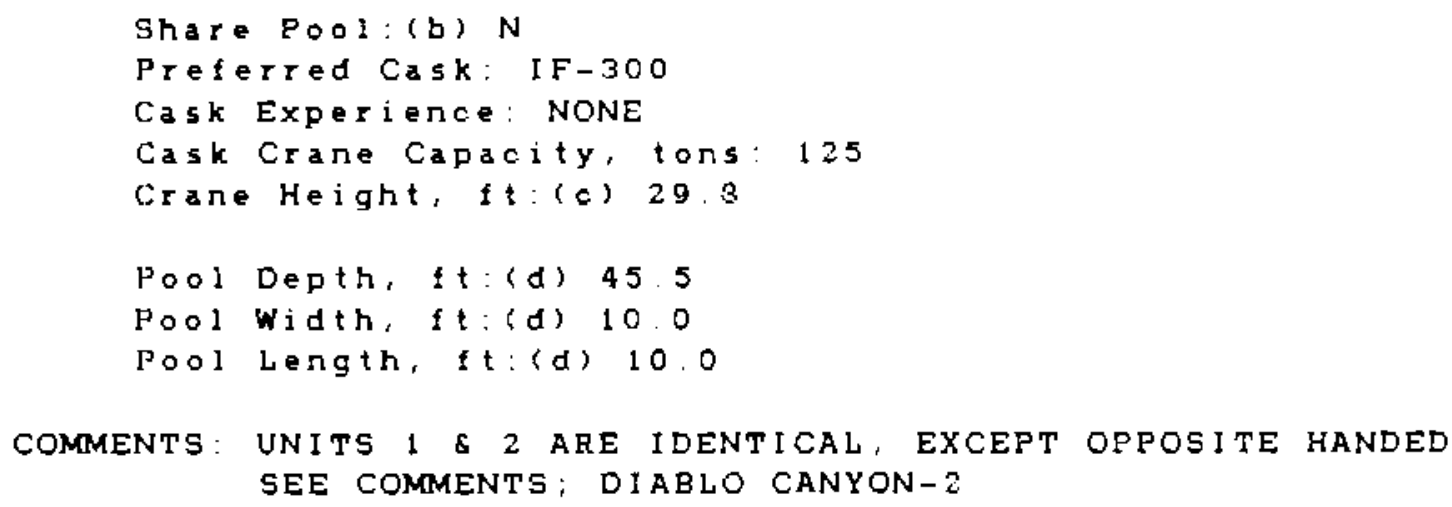

RAIL/GARGE ACCESS DATA:

Rail Spur on Site: NO

Nearest railroad: SAN LUIS

Distance from Rail Spur to Cask Loading bay: 20 miles Source of cooling water: PACIFIC OCEAN

Barge Feasibility: YES

COMMENTS: SEE COMMENTS; DIABLO CANYON- 2

\section{CURREIT CASX HANDLING CAPABILITIES :}

Legal Truek: YES

overweight Truck: YES

a a il: NO

\footnotetext{
(a) Spent Fuel storage Requirements, DOE/RL-84-1, May 19.94

(b) $A$ indicates common pool shared by two reactors

$\exists$ indicates pools connected by transfer canal

$\because$ indicates pools connected by cask transfer

(c) The distance from the operating deck to the bottom of the zane hook at its uppermost position.

(d) Refers to the respective usable dimension bi.e. length. width, or depth) of the cask loading well.
} 
PLANT NAME: DIABLO CANYON-2

UTILITY: PACIFIC GAS AND ELECTRIC CO

NEAREST TOWN: AVILA BEACH, CA

NRC DOCKET NUMBER: $50-323$

REACTOR TYPE: PWR

RATING : (a) $1119 \mathrm{MWe}$

IN PLANT HANDLING PARAMETERS

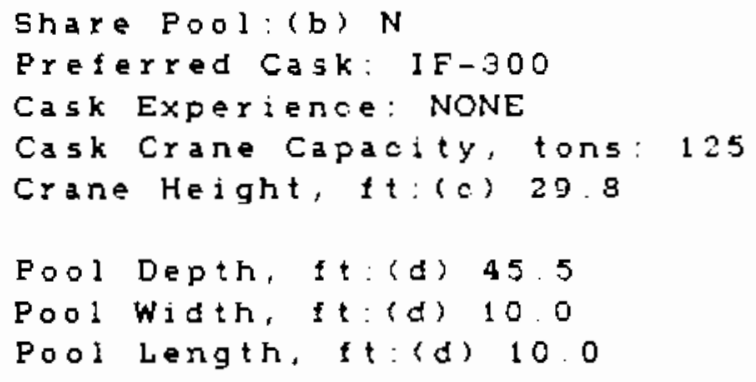

COMMENTS: 70 TON CRANE RATING FOR USE ALTHOUGH LISTED @ 125

TONS. RLANT WAS DESIGNED ASSUMING A 70 TON CASK 5

FT IN DIAMETER, 17.5 FT LONG. A MUCH LARGER CASK

WOULD NOT BE ARPROPRIATE. LITTLE ROOM ON OPERATING

FLOOR AREA $(6-7$ 'WIDE) RATED FOR $1000 \mathrm{LES/SQ}$ FT.

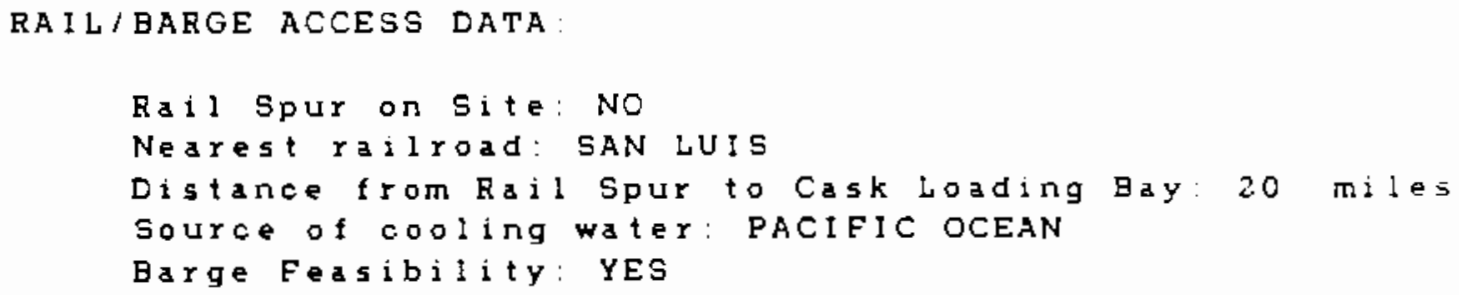

CUREENT CASK HANDLING CAPABILITIES :

Legal Truck: YES

Overweight Truck: YES

Ra i l: NO

\footnotetext{
(a) Spent Fuel storage Requirements, DOE/RL-94-1, May 1994

(b) A indicates common pool shared by two reactors

B indicates pools connected by transter canal

$c$ indicates pools connected by cask transfer

(c) The distance from the operating deck to the bottom of the crane hook at its uppermost position

(d) Refers to the respective usable dimension (i. e., length, width, or depth) of the cask lodding well
} 
PLAN'T NAME: DRESDEN - 1

UTILITY: COMMONWEALTH EDISON COMPANY

NEAREST TOWN: MORRIS, ILL

NRC DCCKET NUMBER: 50-010

REACTOR TYPE: BWR

RATING: (a) $200 \mathrm{MWe}$

IN PLANT HANDLING PARAMETERS:

Share Pool: (b) No

Freferred Cask: TN-g

Cask Experience: NFS-4/NAC $\rightarrow 1$

Cask Crane Capacity, tons: 75

Crane Height, ft:(c) 25.0

Fool Depth, ft: (d) 40.0

Fool Width, it:(d) 10

Eool Length, it: (d) 15.8

COMMENTS: REACTOR WAS SHUT DOWN 10/31/79. LTG. FACTORS: OVERHEAD CRANE CAPABILITIES, AND CLEARANCE CAPABILITIES. POOL IS ONE-OF-A-KIND. CASK DROP ANALYSIS NECESSARY FOR EACH CASK TYPE. CO. OWNS TN-9 AND WOULD PREFER ITS USE

RAIL/BARGE ACCESS DATA :

Rail Spur on Site: YES

Nearest railroda: BALTIMORE AND OHIO

Distance from Rail Spur to Cask Loading Source of cooling water: KANKAKEE RIVER

Earge Feasibility: YES

COMMENTS: EITHER TRUCK OR RAIL MAVE ACCESS. DOCK IS NEARBY

CURRENT CASK HANDLING CAPABILITIES :

l,egal Truck: YES

Cverweight Truck: YES

Ra i l: NO

(a) Spent Fuel Storage Requirements, DOE/RL-84-1, May 1984

(b) $h$ indicates common pool shared by two reactors.

b indicates pools connected by transfer canal

C: indicates pools connected by oask transfer

(c) The distance from the operating deck to the bottom of the crane hook at its uppermost position.

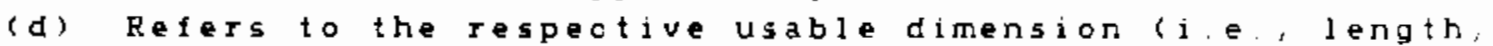
width, or depth) of the cask loading well 
PLANT NAME: DRESDEN-2

UTILITY: COMMONWEALTH EDISON COMPANY

NEAREST TOWN: MORR IS, ILL

NRC DOCKET NUMBER: $50-237$

REACTOR TYPE : EWR

RATING: (a) 794 MWe

IN PLANT HANDLING PARAMETERS:

Share Pool: (b) NO

Preferred Cask: $\mathrm{TN}-\mathrm{9}$

Cask Experience: TN-9. If -300

Cask Crane Capacity, tons: 125

Crane Height, ft: (c) 28.0

Pool Depth, et:(d) $3 ? .8$

Pool Width, ft:(d) 8.0

Pool Length, f $t:(d) 12.0$

COMMENTS: 2 MAJOR PROBLEMS, HATCH SIZE AND GRAPPLE. BOTH LIMIT MAXIMUM CASK LENGTH. UNITS 2 \& 3 SHARE HATCH. PROCEDIJRE TO GET CASK UPRIGHT HAS BEEN MODIFIED SO THEY CAN GET THE TN-9 OUT. IN UNITS $2 \& 3$. NORMAL FUEI CRAPPLE CAN NOT BE RETRACTED FAR ENOUGH ( 8 "SHY)

RAIL/BARGE ACCESS DATA:

Rail Spur on Site: YES

Nearest railioad: BALTIMORE AND OHIO

Distance from Rail Spur to Cask Loading Bay: 0 miles

Source of cooling water: COOLING LAKE

Barge Feasibility: YES

COMMENTS: SEE COMMENTS; DRESDEN-3

CURRENT CASK HANDLING CAPABILITIES :

Lega! Truck: YES

Overmeight Truck: YES

Rail: YES

(a) Spent Fuel Storage Requirements, DOE/RL-84-1, May 1984.

(b) A indicates common pool shared by two reactors.

B indicates pools connected by transter canal

C indicates pools connected by cask trangfer

(c) The distance from the operating deck to the bot tom of the crane hook at its uppermost position

(d) Refers to the respective usable dimension (i.e., length, width, or depth) of the cask loading well. 
PLANT NAME : DRESDEN-3

UTILITY: COMMONWEALTH EDISON COMPANY

NEAREST TOWN : MORRIS, ILL

NRC DOCXET NUMBER: $50-249$

REACTOR TYPE : BWR

RAT ING : (a) $794 \mathrm{MWe}$

IN PLANT HANDLING PARAMETERS:

Share Pool: (b) NO

Preferred Cask: TN-9

Cask Experience: TN-9; IF-300

Cask Crane Capacity, tons: 125

Crane Height, $f t:(c) 28.0$

Poot Depth, ft: (d) 37.8

Pool Width, ft: (d) 8.0

Pool Length, ft: (d) 12.0

COMMENTS: UNITS 2 AND 3 ARE SIMILAR. SEE NOTES ON UNIT 2 . FULL RAISED POSITION OF CRANE GIVES $28.0^{\circ}$ HEIGHT. LOSE ABOUT 2' DUE TO HOOKUP W/YOKE. 24.5' IS DISTANCE TO LOWER I-BEAM. NO WELL, CASK WOULD BE SET ON A PAD IN THE POOL

RAIL / BARGE ACCESS DATA :

Rajl Spur on Site: YES

Nearest rai!road: BALTIMORE AND OHIO

Distance from Rail Spur to Cask Loading Bay: 0 miles

Source of cooling water: COOllNG LAKE

Barge Feasibility: YES

COMMEN'S: RAILSPUR HASN'T BEEN USED IN A WHILE. IN ILLINOIS. IN GENERAL HAVE BEEN ABLE TO GET NECESSARY TRANSPORTATION PERMITS EXCEPT IN INCLEMENT WEATHER .

CURRENT CASK HANDLING CAPABILITIES:

Legal Truck: YES

Overwe ight Truck: YES

Rail: YES

(a) Soent Fuel storage Requirements, DOE/RL-84-1, May 1984

(b) A indicates common pool shared by two reactors.

B indicates pools connected by transfer cana!.

$C$ indicates pools connected by cask tiansfer.

(c) The distance from the operating deck to the bottom of the crane hook at its uppermost position.

(d) Refers to the respective usable dimension $(1 . e$. , length, width, or depth) of the cask loading well.

A. 35 
PLANT NAME: DUANE ARNOLD

UTILITY: IOWA ELECTRIC LIGHT AND POWER CO.

NEAREST TOWN: PALO, 1 OWA

NRC DOCKET NUMBER: 50-331

REACTOR TYPE : BWR

RATING : (a) 515 MWe

IN PLANT HANDLING PARAMETERS:

Share Pool: (b) NO

Preferred Cask: SEE COMMENTS

Cask Experience:

Cask Crane Capacity, tons: 100

Crane Height, $f t:(c) 25$

Pool Depth, ft: (d) 39.1

Pool Width, ft: (d) 9.0

Pool Length, ft: (d) 10.0

COMMENTS: FLOOR LIMIT- 1000 LB/SQ. FT. ALSO, HAVE WORKED WITH A G.E. $\quad 1 F-300$

RAIL/BARGE ACCESS DATA :

Rail Spur on Site: YES

Nearest railroad: IOWA NORTHERN RAILROAD

Distance from Rail Spur to Cask Loading Bay: 0 miles

Source of cooling ater: CEDAR RAPIDS RIVER

Barge Feasibility: NO

COMMENTS :

CURRENT CASK HANDLING CAPABILITIES:

Legal Truck: YES

Overwoight Truck: YES

Rail: YES

(a) Spent Fuel storage Requirements, DOE/RL-84-1, May 1984.

(b) A indicatos common pool shared by two reactors.

B indicates pools connected by transfer canal.

C indicates pools connected by cask transer.

(c) The distance from the operating deck to the bottom of the crane hook at its uppermost position.

(d) Refers to the respective usable dimengion (i.e., length, width, or depth) of the cask loading well. 
PLANT NAME : FARLEY-1

UTILITY: ALABAMA POWER CO

NEAREST TOWN: DOTHAN, ALA

NRC DOCKET NUMBER: $50-348$

REACTOR TYPE: PWR

RATING: (a) $804 \mathrm{MWe}$

IN PLANT HANDLING PARAMETERS:

Share pool: (b) No

Preferred Cask: NO

Cask Experience: NONE

Cask Crane Capacity, tons: 125

Crane Height, $f \mathrm{t}:(\mathrm{c}) 20.3$

Pool Depth, ft:(d) 40.6

$0_{0} 01$ Width, ft: (d) $1 \pm .0$

Poo! Length, f $t:(d) 13.3$

COMMENTS : 2 SPENT FUEL POOLS, BUTT UP AGAINST EACH OTHER WITH ONE COMMON WALL AND A SHARED CRANE. MUST PROOF TEST LIFTING CAPACITY OF CRANE BEFORE USING IT TO LIFT A CASK CONTAINING SPENT FUEL.

RAIL/BARGE ACCESS DATA:

Rail Spur on Site: YES

Nearest rail l oad: CENTRAL OF GEORGIA

Distance from Rail Spur to Cask Loading Bay: 0 miles Source of cooling water: CHATAHOOCHEE RIVER

Barge Feasibility: YES

COMMENTS: RAIL SPUR COMES UNDERNEATH CRANE. CRANE CAN SET CASK DIRECTLY ON RAIL CAR EVEN THOUGH SPUR DOES NOT EXTEND INTO CASK LOADING BAY PER SE. BARGE UNLOADING FACILITY MAY STILL EXIST AND NOT HARD TO RECONSTRUCT USED TO BRING REACTOR VESSELS ON-SITE.

CURRENT CASK HANDLING CAPABILITIES:

Legal Truck: YES

Jverweight Truck: YES

Ra i l: YES

(a) Spent Fuel Storage Requirements, DOE/RL-84-1, May 1984

(b) A indicates common pool shared by two reactors.

B lndicates pools connected by transfer canal.

z indicates pools connected by cask transfer.

(c) The distance from the operating deck to the bottom of the crane hook at its uppermost position.

(d) Refers to the respective usable dimension (i.e., length, width, or depth) of the cask loading well. 
PLANT NAME : FARLEY -2

UTILITY: ALABAMA POWER CO

NEAREST TOWN: DOTHAN, $\Lambda L A$

NRC DOCKET NUMBER: $50-364$

REACTOR TYPE : PWR

RATING : (a) $814 \mathrm{MWe}$

IN PLANT HANDLING PARAMETERS:

Share Pool: (b) No

Preferred Cask: NONE

Cask Experience: NO

Cask Crane Capacity, tons: 125

Crane Height, ft: (c) 20.3

Pool Depth, ft:(d) 40.6

Pool width, Et: (d) 11.0

Pool Length, ft: (d) 13.3

COMMENTS: UNITS 1 AND 2 ARE IDENTICAL EXCEPT ONE IS A MIRROR IMAGE OF THE OTHER. SEE COMMFNTS; FARLEY-1

RAIL/BARGE ACCESS DATA:

Rail Spur on Site: YES

Nearest rail road: CENTRAL OF CEORGIA

Distance from Rail Spur to Cask Loading Bay: 0 miles

Source of cooling water: CHATAHOOCHEE RIVER

Barge Feasibility: YES

COMMENTS : SEE COMMENTS; FARLEY 1 .

CURRENT CASK HANDLING CAPABILITIES:

Lega) TrucK: YES

Overweight Truck: YES

Rail : YES

(a) Spent Fuel storage Requirements, DOE/RL-84-1, May 1984

(b) A indicates common pool shared by two reactors.

B indicates pools connected by transter canal

$C$ indicates pools connected by cask transfer.

(c) The distance from the operating deck to the bottom of the crane hook at its uppermost position.

(d) Refers to the respective usable dimension (i.e., length, width, or depth) of the cask loading we!l 
PLANT NAME : FERM! -2

UTILITY: DETROIT EDISON COMPANY

NEAREST TOWN : NEWPORT, MICH.

NRC DOCKET NUMBER: $50-341$

REACTOR TYPE : BWR

RATING : (a) $1093 \mathrm{MWe}$

IN PLANT HANDLING PARAMETERS:

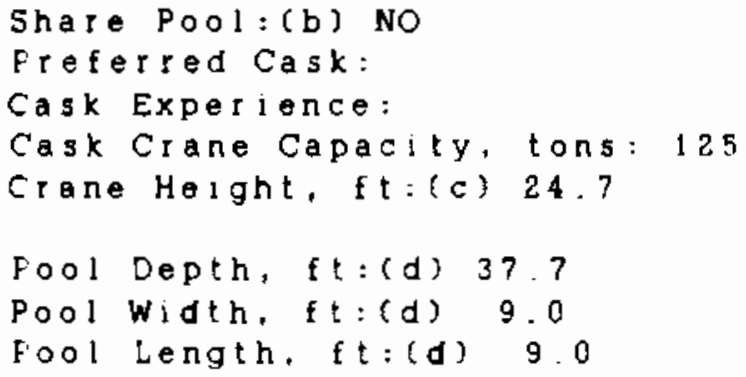

COMMENTS :

RAIL/EARGE ACCESS DATA:

Rail Spur on Site: YES Nearest railroad: DETROIT AND TOLEDO SHORE LINE Distance from Rail Spur to Cask Loading Bay: 0 miles Source of cooling water: LAKE ERIE Barge Feasibility: YES

COMMENTS :

CURRENT CASX HANDLINO CAPABILITIES:

l.ega: Truck: YES

Cverwejght Truck: YES

Hail: YES

(a) ispent Fuel Storage Requirements, DOE/RL-84-1, May 1984.

(b) A indicates common pool shared by two reactors.

B indicates pools connected by transfer cana!.

$C$ indicates pools connected by cask transfer.

(c) The distance from the operating deck to the bot om of the crane hook at its uppermost position.

(d) Refers to the respective usable dimension (i.e., length, width, or depth) of the cask loading we!l. 
PLANT NAME: FITZPATRICK

UTILITY: POWER AUTH. OF STATE OF NY

NEAREST TOWN : SCRIBA, NY

NRC DOCKET NUMBER: $50-333$

REACTOR TYPE : BWR

RATING : (a) B21 MWe

IN PLANT HANDLING PARAMETERS:

Share Pool: (b) NO

Preferred Cask: NONE SPECIFIED

Cask Experience:

Cask Crane Capacity, tons: 125

Crane Height, $f t:(c) 40$

Pool Depth, ft: (d) 39

Pool Width, f $t:(d) 12$

Pool length, ft: (d) 14

COMMENTS :

RAIL/BARGE ACCESS DATA:

Rail Spur on Site: YES

Nearest railroad: CONRAll

Distance from Rail Spur to Cask Loading Bay: 0 miles

Source of cooling water: LAKE ONTARIO

Barge Feasibility: YES

COMMENTS: THE RAILROAD SERVING THIS SITE HAS NOT BEEN USED FOR SOME TIME .

CURRENT CASK HANDLING CAPABILITIES:

Legal Truck: YES

Overweight Truck: YES

Rai 1: YES

(a) Spent Fuel Storage Requirements, DOE/RL-84-1, May 1984.

(b) A indicates common pool shared by two reactors.

B indicates pools connected by transfer canal.

C indicates pools connected by cask tiansfer.

(c) The distance from the operating deck to the bottom of the crane hook at its uppermost position.

(d) Refers to the respective usable dimension (i.e., length, width, or depth) of the cask loading well. 
PLANT NAME: FORT CALHOUN-1

UTILITY: OMAHA PUBLIC POWER DISTRICT

NEAREST TOWN: FORT CALHOUN, NEB

NRC DOCKET NUMBER: $50-285$

REACTOR TYPE : PWR

RATING: (a) 4 ? $1 \mathrm{MWe}$

IN PLANT HANDLING PARAMETERS:

Share Pool: (b) NO

Preferred Cask:

Cask Experience:

Cask Crane Capacity, tons: 75

Crane Height, $\mathrm{ft}:(\mathrm{c}) 28.2$

Pool Depth, ft: (d) 44.0

Pool width, ft:(d) 7.3

Pool Length, ft: (d) 7.7

COMMENTS :

RAIL/BARGE ACCESS DATA :

Rail Spur on Site: NO

Nearest I ailroad: CHICAGO AND NORTHWESTERN

Distance from Rail Spur to Cask Loading Bay: 6 miles

Source of cooling ater : MISSOURI RIVER

Barge Feasibility: YES

COMMENTS: REACTOR VESSEL AND STEAM GENERATORS SHIPPED BY BARGE.

CURRENT CASK HANDLING CAPABILITIES:

Legal Truck: YES

Overweight Truck: YES

Rail: No

(a) Spent Fuel Storage Requirements, DOE/RL-8ł-1, May 1984 .

(b) A indicates common pool shared by two reactors.

B indicates pools connected by transter cana!.

$C$ indicates pools connected by cask transfer.

(c) The distance from the operating deck to the bottom of the crane hook at its uppermost position.

(d) Refers to the respective usable dimension (i.e... length, width, or depth) of the cask loading we!l 
PLANT NAME : GINNA

UTILITY: ROCHESTER GAS AND ELECTRIC CORP.

NEAREST TOWN : ONTAR!O, NY

NRC DOCKET NUMBER: $50-244$

REACTOR TYPE: PWR

RATING: (a) 470 MWe

IN PLANT HANDLING PARAMETERS:

Share Pool: (b) NO

Preferred Cask: NLI-1/2

Cask Experience: NAC-1 NFS-4

Cask Crane Capacity, tons: 40

Crane Helght, $f t:(c)$

Poo! Depth, ft: (d) 40

Pool Width, ft: (d) 12.4

Pool Length, f $t:(d) 12.4$

COMMENTS: WITHIN THE SPENT FUEL POOL AREA, A 153 SQ. FT AREA IS SET ASIDE FOR CASK HANDLING OPERATIONS

RAIL/BARGE ACCESS DATA:

Rail Spur on Site: NO

Nearest railroad: ONTARIO MIDLAND

Distance from Rail Spur to Cask Loading Bay: 5 miles Source of cooling water: LAKE ONTARIO

Barge Feasibility: NO

COMMENTS :

CURRENT CASK HANDLING CAPABILITIES:

Lega l Truck: YES

Overweight Truck: No

Ra i l: NO

(a) Spent Fuel storage Requirements, DOE/RL-84-1, May 1984

(b) A indicates common pool shared by two reactors.

B Indicates pools connected by transfer canal.

C indicates pools connected by cask transfer.

(c) The distance from the operating deck to the bottom of the crane hook at its uppermost position.

(d) Refers to the respective usable dimension (1.e., length, width, or depth) of the cask loading well. 
PLANT NAME: GRAND GULF-1

UTILITY: MISSISSIPPI POWER AND LIGHT CO

NEAREST TOWN : PORT GIBSON, MISS

NRC DOCKET NUMBER: $50-416$

REACTOR TYPE : BWR

RATING : (a) $1254 \mathrm{MWe}$

IN PLANT HANDLING PARAMETERS:

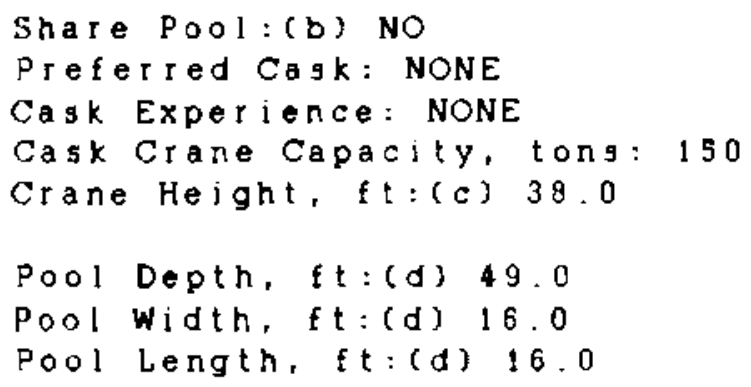

COMMENTS: REACTORS 1,2, AND FUEL HANDLING SYSTEMS ARE SIMILAR ALTHOUGH THEY DO NOT SHARE A POOL

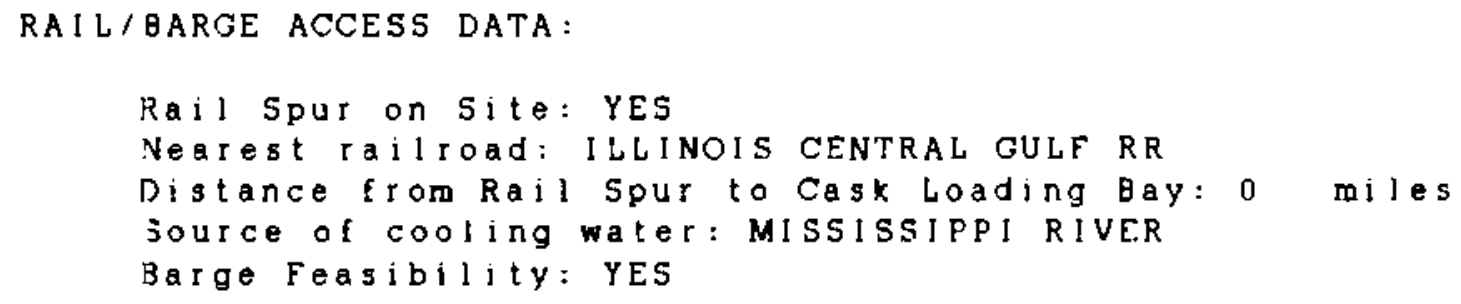

COMMENTS: NO RAIL LIMITS KNOWN. USED BARGE ON MISSISSIPPI RIVER DURING CONSTRUCTION.

\section{CURREVT CASK HANDLING CAPABILITIES:}

segal Truck: YES

Dverweight Truck: YES

Rail : YES

(a) Spent Fuel Storage Requirements, DOE/RL-84-1, May 1984.

(b) A indicates common pool shared by two reactors.

B indicates pools connected by transfer canal.

Q indicates pools connected by cask transfer

(c) The distance from the operating deck to the bottom of the crane hook at its uppermost pogition.

(d) Refers to the respective usable dimension (j.e.. length, width, or depth) of the cask loading well. 
PLANT NAME : GRAND GULF- 2

UTILITY: MISSISSIPPI POWER AND LIGHT CO

NEAREST TOWN : PORT GIBSON, MISS

NRC DOCKET NUMBER: $50-417$

REACTOR TYPE: BWR

RATING:(a) $1250 \mathrm{MWe}$

IN PLANT HANDLING PARAMETERS:

Share Pool: (b) NO

Preferred Cask: NONE

Cask Experience: NONE

Cask Crane Capacity, tons: 125

Crane Height. f $t:(c) 38.0$

Pool Depth, ft: (d) 49.0

Pool Width, ft: (d) 16,0

Pool Length, ft: (d) 16.0

COMMENTS: SEE COMMENTS; GRAND GULF-1

RA!L/BARGE ACCESS DATA:

Rail Spur on Site: YES

Nearest railroad: ILLINOIS CENTRAL GULF RR

Distance from Rail Spur to Cask Laading Bay: 0 miles

Source of cooling water: MISSISSIPPl RIVER

Barge Feasibility: YES

COMMENTS: SEE COMMENTS; GRAND GULF-1.

CURRENT CASK HANDLING CAPABILITIES:

Legal Truck: YES

Overweight Truck: YES

Ra i l: YES

(a) Spent Fuel Storage Requirements, DOE/RL-84-1, May 1984

(b) A indicates common pool shared by two reactors.

$B$ indicates pools connected by trangler canal.

$C$ indicateg pools connected by cask transfer.

(c) The digtance from the operating deck to the bottom of the crane hook at its uppermost position.

(d) Refers to the respective usable dimension (1.e., length, width, or depth) of the cask loading wel! . 
PLANT NAME: HADDAM NECK

UT ILITY: NORTHEAST UTILITIES

NEAREST TOWN : HADDAM NECK, CONN.

NRC DOCKET NUMBER: $50-213$

REACTOR TYPE : PWR

RATING : (a) 582 MWO

IN PLANT HANDLING PARAMETERS:

Share Pool: (b) NO

Preferred Cask: NONE

Cask Experience: IF-200, NAC-1

Cask Crano Capacity, tons: 100

Crane Height, $f t:(c) 2 B$

Pool Depth, ft:td) 39

Pool Width, ft:(d) 6.5

Pool Length, $f t:(d) 6.5$

COMMENTS: INFORMATION FROM FSAR NOT YET VERIFIED. B3 BUNDLES WERE SENT OFF-SITE 7-8 YEARS AGO.

RAIL/BARGE ACCESS DATA :

Rail Spur on Site: NO

Nearest rail road: CONRAIL

Distance from Rail Spur to Cask Loading Bay: 15 milos

Sourco of cooling water: CONNECTICUT RIVER

Bargo Foasibility: YES

COMMENTS: GROSS WEIGHTS OVER 100 TONS ALLOWED ON ACCESS ROADS.

CURRENT CASK HANDLING CAPABILITIES:

Legal Truck: YES

Overweight Truck: YES

Rail: NO

(a) Spent Fuel Storage Requiroments, DOE/RL-84-1, May 1984.

(b) A indicates common pool shared by two reactors.

B indicates pools connected by transter canal.

$C$ indicates pools connected by cask transfor.

(c) The distance from the operating deck to the bottom of the crane hook at its uppermost position.

(d) Refers to the respective usable dimension (i.e., length, width, or depth) of the cask loading well.

A. 45 
PLANT NAME: HARRIS - 1

UT ILITY: CAROLINA POWER AND LIGHT

NEAREST TOWN : NEWHILL, NC

NRC DOCKET NUMBER: $50-400$

REACTOR TYPE: PWR

RATING: (a) $900 \mathrm{MWe}$

IN PLANT HANDLING PARAMETERG:

Shate Pool: (b) NO

Preferred Cask: I $5-300$

Cask Exper lence:

Cask Crane Capacity, tons: 150

Crane Height, ft: (c) 27.0

Pool Depth, ft: (d) 35.0

Pool Width, ft: (d) 12.0

Pool Length, ft: (d) 12.0

COMMENTS :

RAIL/BARGE ACCESS DATA:

Rail Spur on Site: YES

Nearest railroad: SEABOARD COASTLINE

Distance from Ral! Spur to Cask loading Bay: 0 miles

Source of cooling water: BUCKHORN CREEK

Barge Feasibi! tty: NO

COMMENTS :

CURRENT CASK HANDLING CAPABILITIES:

Legal Truck: YES

Overweight Truck: YES

Rail : YES

(a) Spent Fuel storage Requirements, DOE/RL-84-1, May 1984

(b) A indicates common pool shared by two reactors

$B$ indicates pools connected by transfer canal

C indicates pools connected by cask tianser.

(c) The distance from the operating deck to the bottom of the crane hook at its uppermost position.

(d) Refers to the respective usable dimension (i.e., length, width, or depth) of the cask loading well. 
PLANT NAME : HATCH -1

UT ILITY : GEORGIA POWER COMPANY

NEAREST TOWN : BAXLEY, GA

NRC DOCKET NUMBER: $50-321$

REACTOR TYPE: BWR

RATINC: : (a) 765 MWe

IN PLANT HANDLING PARAMETERS:

Shate Pool:(b) B

Preferred Cask: $1 \mathrm{~F}-300$

Cask Experience: NO

Cask Crane Capacity, tons: 125

Orane Height, $f t:(c) 28.0$

Pool Depth, ft:(d) 39.0

Pool width, ft: (d) 12.0

Jool length, ft: (d) 14.0

COMMENTS: IN GENERAL DESIGNED FOR IF-300, BUT CAN HANDLE CASKS UP TO 125 TONS. YOKE PIN HANDLES ONLY 70 TONS. WOULD NEED MODIFIED YOKE PIN FOR HEAVIER CASKS.

RAIL/BARGE ACCESS DATA:

Rail Spur on Site: YES

Nearest railroad: SOUTHERN RAILWAYS

Distance from Rail Spur to Cask Loading Bay: 0 miles Source of cooling water: ALTAMAHA RIVER

Barge Feasibility: NO

COMMENTS: NO PLANS TO ANALYZE ROAD LIMITS PRIOR TO ACTUAL SHIPMENT OF SPENT FUEL. BARGE ACCESS IS NOT FEASIBLE. LAST

SUMMER DERATED POWER BECAUSE OF DROUGHT CONDITIONS.

CURRENT CASK HANDLING CAPABILITIES:

Legal Truck: YES

Overweight Truck: YES

Ra i I : YES

(a) Spent Fuel Storage Requirements, DOE/RL-84-1, May 1984

(b) A indicates common pool shared by two reactors.

3 indicates pools connected by transfer canal.

( indicates pools connected by cask transfer.

(c) The distance from the operating deck to the bottom of the crane hook at its uppermost position.

(d) Refers to the respective usable dimension (i.e., length. width, or depth) of the cask loading well. 
PLANT NAME : HATCH - 2

UTILITY: GEORGIA POWER COMPANY

NEAREST TOWN : BAXLEY, GA

NRC DOCKET NUMBER: $50-366$

REACTOR TYPE: BWR

RATING: (a) 775 MWe

IN PLANT HANDLING PARAMETERS:

Share Pool:(b) B

Preferred Cask: $1 F-300$

Cask Experience: NONE

Cask Crane Capacity, tons: 125

Crane Height, $f t:(c) 28.0$

Pool Depth, ft:(d) 39.0

Pool Width, $t \mathrm{t}:$ (d) 12.0

Pool Length, ft: (d) 14.0

COMMENTS: NO SPENT FUEL SHIPPING HAS OCCURRED. SEE COMMENTS; $\mathrm{HATCH}-1$.

RAIL/BARGE ACCESS DATA :

Rail Spur on Site: YES

Nearest railroad: SOUTHERN RAILWAYS

Distance from Rail Spur to Cask Loading Bay: 0 miles

Source of cooling water: ALTAMAHA RIVER

Barge Feasibility: NO

COMMENTS :

CURRENT CASK HANDLING CAPABILITIES:

Legal Truck: YES

Overweight Truck: YES

Ra: l : YES

(a) Spent Fuel Storage Requirements, DOE/RL-84-1, May 1984.

(b) A indicates common pool shared by two reactors.

$B$ indicates pools connected by transter canal.

C indicates pools connected by cask transfer.

(c) The distance from the operating deck to the bottom of the crane hook at its uppermost position.

(d) Refers to the respective usable dimenston ( 1 .e., length, width, or depth) of the cask loading well

$$
\text { A. } 48
$$


PLANT NAME: HOPE CREEK-1

UTILITY: PUBLIC SERVICE ELECTRIC AND GAS CO

NEAREST TOWN: SALEM, NJ

NRC DOCKET NUMBER: $50-354$

REACTOR TYPE: BWR

RATING: (a) 1067 MWe

IN PLANT HANDLING PARAMETERS

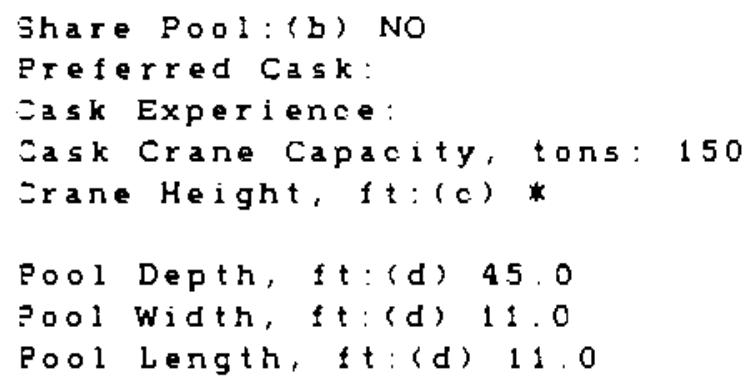

COMMENTS: SCHEDULED FOR COMMERCIAL OPERATION IN FALL OF 1936

*ALTHOUGH CRANE HEIGHT WAS NOT KNOWN, IT IS GREAT

ENOUGH TO ALLOW THE HANDLING OF AN IF 300 CASK

RAIL/BARGE ACCESS DATA:

Rail Spur on Site: NO

Nearest railroad: CONRAIL

Distance from Rail Spur to Cask Loading Bay: 15 miles

Source of cooling water: DELAWARE RIVER

Barge Feasibility: YES

COMMENTS :

CURRENT CASK HANDLING CAPABILITIES:

Lega 1 Truek: YES

Juerweight Truck: YES

Qail: NO

(a) Spent Fuel storage Requirements, DOE/RL-34-1, May 1984.

(b) A indicates common pool shared by two reactors

a indicates pools connected by transter canal

Findicates pools connected by cask transter

(c) The distance from the operating deck to the bottom of the crane hook at its uppermost position

(d) Refers to the respective usable dimension ( 1 e, length, width, or depth) of the cask loading well 
PLANT NAME: HUMBOLDT BAY

UTILITY: PACIEIC GAS AND ELECTRIC CO.

NEAREST TOWN : EUREKA

NRC DOCKET NUMBER: $50-133$

REACTOR TYPE: BWR

RATING: (a) 63 MWe

IN PLANT HANDLING PARAMETERS:

Share Pool: (b) NO

Preferred Cask: NFS-100

Cask Experience: NFS-100

Cask Crane Capacity, tons: 75

Crane Height, f $t:(c) 24.0$

Pool Depth, ft:(d) 36.0

Poo! Width, ft: (d) 12.5

Pool Length, $f t:(d) 10.0$

COMMENTS: HUMBOLDT BAY IS CURRENTLY BEINC DECOMMISSIONED. CASK

HANDLING OPERATING PROCEDURES LIMIT CASK HANDI,ING

AREA TO CASK PIT AND AREA IMMEDIATELY ADJACENT TO

SPENT FUEL POOL. UPPER LIMIT >100 TONS

RAIL/BARGE ACCESS DATA:

Rail Spur on site: NO

Nearest rail road: NORTHWESTERN PACIFIC RR

Distance from Rail Spur to Cask Loading Bay: 0 miles

Source of cooling water: HUMAOl,DT RAY

Barge Feasibility: NO

COMMENTS: ONE SOURCE BELIEVES RAILSPUR HAS BEEN MADE NON-FUNCTIONAL

"RAILROAD DOORS" OPENING $15^{\prime} \mathrm{W} \times 16^{\prime} \mathrm{H}$. REACTOR IS

ON HUMBOLDT BAY OFF THE PACIFIC OCEAN, BUT THERE

IS NO DOCK. SPENT FUEL SHIPMENTS USINC THE NRS-10O

WERE MADE FROM 1970-1971

CURRENT CASK HANDLING CAPABILITIES:

Legal Truck: YES

Overwelght Truck: YES

Rail: NO

(a) Spent Fuel Storage Requitements, DOE/RL-84-1, May 1984

(b) A indicates common pool shared by two reactors.

B indicates pools connected by transfer canal.

$C$ indicates pools connected by cask transfer.

(c) The distance from the operating deck to the bot tom of the crane hook at its uppermost position.

(d) Refers to the respective usable dimension (i. e., length, width, or depth) of the cask loading well. 
PLANT NAME: INDIAN POINT- 1

UTILITY: CONSOLIDATED EDISON CO. OF NEW YORK

NEAREST TOWN : INDIAN POINT, NY

NRC DOCKET NUMBER: $50-3$

REACTOR TYPE: PWR

RATING: (a) $265 \mathrm{MWe}$

IN PLANT HANDLING PARAMETERS:

Share Pool: (b) NO

Fief er red Cask: I $F-300$

Cask Experience: GE IF-200

Cask Crane Capacity, tons: 75

Cirane Height, ft:(c) 18.0

Hool Depth, ft:(d) 40.0

Fool width, ft: (d) 10.0

Pool length, ft: (d) 19.0

COMMENTS: CASK SIZE LIMITED BY INSUFFICIENT ROOM TO IIFT CASK. OFF TRAILER; CRANE HEIGHT IN BLDG PREVENTS USF OF A VERY LONG CASK. CASK DIAMETER LIMITED BECAUSE PAD IT RESTS UPON IS ONLLY ABOUT 3 FT. D. WOULD NFE. NEW LARGER PAD FOR LARGER CASK.

RAIL/BARGE ACCESS DATA:

Rail Spur on Site: NO

Nearest rail road: CONSOLIDATED RAIL

Distance from Rail Spur to Cask Loading Bay: $1.5 \mathrm{miles}$ Source of cooling water: HUDSON RIVER

Barge Feasibility: YES

COMMENTS: 10 YRS AGO STUDIED USE OF GE IF-300 CASK. 3 CASES 1) CULVERT BRIDGE WT. LIM PROALEM. 2) ANOTHER BRIDGE W/WTLIMS, 3) BUILD A SECOND RAIL SIDING, THIS IS PROBABLY WHAT WOULD HAVE TO RE DONE. WHARF ON HUDSON IS MAINTAINED AND AVAILABLE.

CURRENT CASK HANDLING CAPABILITIES:

L.egal Truck: YES

Gverweight Truck: NO

F.ail: NO

(a) Sipent ruel storage Requirements, DOE/Rl-84-1, May 1984

(b) $A$ indicates common pool shared by two reactors

1) indicates pools connected by transfer canal.

C: indicates pools connected by cask transfer

(c) The distance from the operating deck to the bottom of the orane hook at its uppermost position.

(d) Refers to the respective usable dimension (i.e., length, width, or depth) of the cask loading well. 


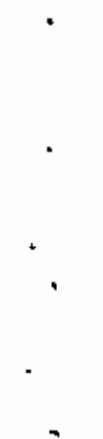


PLANT NAME: INDIAN POINT-2

UTILITY: CONSOLIDATED EDISON CO. OF NEW YORK

NEAREST TOWN: INDIAN POINT, NY

NRC DOCKET NUMBER: $50-247$

REACTOR TYPE : PWR

RATING: (a) 873 MWe

IN PLANT HANDLING PARAMETERS :

Share Poo!:(b) No

Freferred Cask: NONE

Cask Experience: NONE

Cask Crane Capacity, tons: 40

Crane Helght, ft: (c) 24.0

Fool Depth, ft: (d) 40.4

Pool Width, ft: (d) 8,0

Fool Length, $f t:(d) \quad 8.0$

COMMENTS: NEVER HAD A CASK IN UNIT 2 POOL. CRANE HEICHT LIMITS POSSIBLE LENGTH OF CASK. CASK IN VERTICAL POSITION WOULD HAVE TO BE LJFTED OVER BOTH A WALL AND A GUARD RAIL.

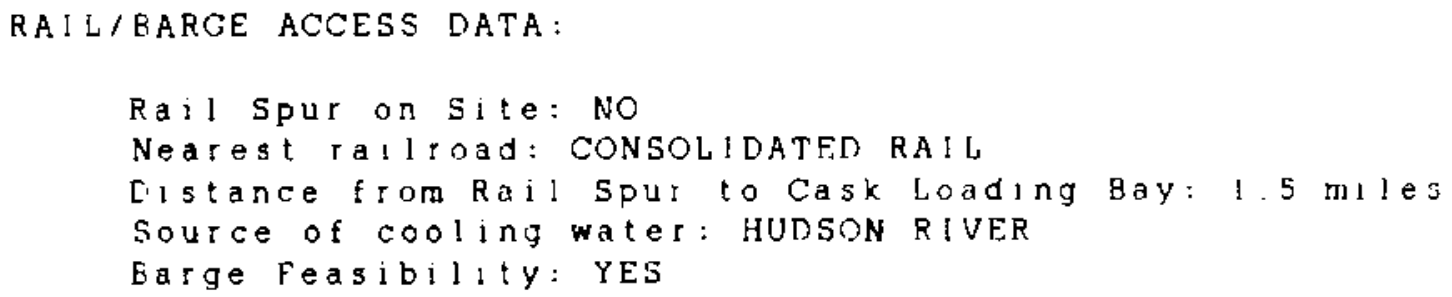

Rail Spur on Site: NO

Nearest ra!lioad: CONSOLIDATFD RAIL

[istance from Rail Spur to Cask Loading Bay: 1.5 miles Source of cooling water: HUDSON RIVER

Barge Feasibility: YES

COMMENTS: SEE COMMENTS; INDIAN POINT-1

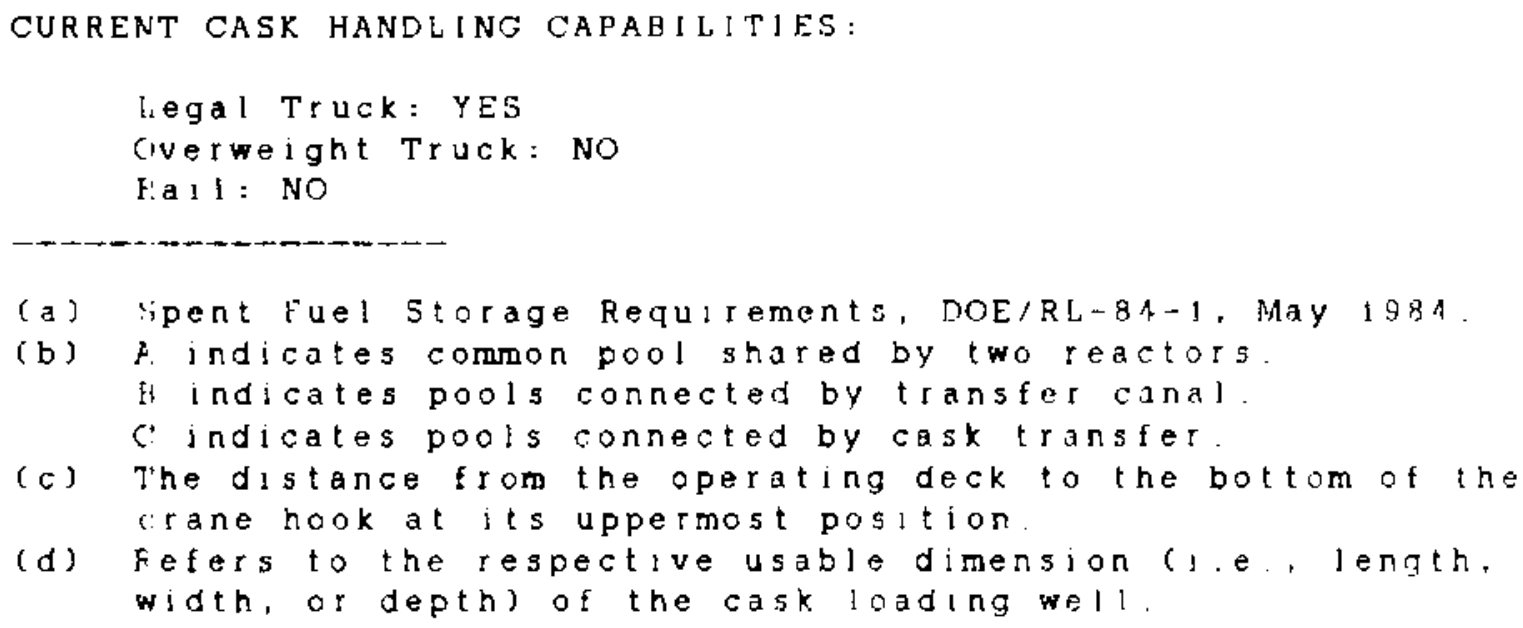


PLANT NAME: INDIAN POINT-3

UTILITY: POWER AUTH. OF THE ST. OF NY

NEAREST TOWN: INDIAN POINT, NY

NRC DOCKET NUMBER: $50-286$

REACTOR TYPE : PWR

RATING:(a) $965 \mathrm{MWe}$

I N PLANT HANDLING PARAMETERS:

Share Pool: (b) NO

Preferred Cask: TRUCK

Cask Experjence: NONE

Cask Crane Capacity, tons: 40

Crane Height, ft: (c) 24

Pool Depth, ft:(d) 40.0

Pool width, ft: (d) 7.9

Pool Length, ft: (d) 8,4

COMMENTS: CRANEHEIGHT IS MEASURED, IN THIS CASE, AS DISTANCE

FROM MIDPOINT OF HOOK ON CRANE TO CENTER OF RAIL.

SEE COMMENTS; INDIAN POINT-2.

RAIL/BARGE ACCESS DATA:

Rail Spur on Site: NO

Nearest rall road: CONSOLIDATED RAIL

Distance from Rail Spur to Cask Loading Bay: 1.5 miles

Source of cooling ater: HUDSON RiveR

Barge Feasibility: YES

COMMENTS: SEE COMMENTS; INDIAN POINT-1

CURRENT CASK HANDLING CAPABILITIES:

Legal Truck: YES

Overweight Truck: NO

Rai 1: NO

(a) Spent Fuel Storage Requirements, DOE/RL-84-1, May 1984

(b) A indicates common pool shared by two reactors.

a indicates pools connected by transier canal.

$C$ indicates pools connected by cask transfer.

(c) The distance from the operating deck to the bottom of the crane hook at its uppermost position.

(d) Refers to the respective usable dimension (1.e., length. width, or depth) of the cask loading well. 
PLANT NAME : KEWAUNEE

UTILITY: WISCONSIN PUBLIC SERVICE CORPORATION

NEAREST TOWN : CARLTON, WIS

NRC DOCKET NUMBER: $50 \rightarrow 305$

REACTOR TYPE: PWR

RAT INO: (a) 520 MWe

IN PLANT HANDLING PARAMETERS:

Share Pool: (b) No

Preferred Cask:

Cask Experience: NONE

Cask Crane Capacity, tons: 125

Crane Height, $f t:(c) \quad 29.6$

Pool Depth, ft: (d) 40.8

Pool Width, ft: (d) 9.5

Pool Length, $f t:(d) \quad 9.5$

COMMENTS: OCTAGONAL BEAR!NG PLATE IN POOL MEASURES 9.5 ' FROM FLAT TO FLAT ON OCTAGON. POOL ACTUALLY MEASURES 17.2, $X$ 18.9'. PLANT WAS DESIGNED TO HANDLE $40 \mathrm{~T}$ TRUCK CASK OR 110 T RAIL CASK. WEIGHT IS PROBABLY LIMITED BY OVERHEAD CRANE CAPACITY OF $125 \mathrm{~T}$.

RAIL/BARGE ACCESS DATA:

Rail Spur on Site: NO

Nearest rail road: GREEN BAY AND WESTERN

Distance from Rail Spur to Cask Loading Bay: 5 miles

Source of cooling water: LAKE MICHIGAN

Barge Feasibility: YES

COMMENTS: LOCATED ON LAKE, BUT 1T IS UNCLEAR WHETHER THERE IS BARGE ACCESS. THERE IS NO LANDING, BUT THERE IS A DEEP-WATER PORT ON THE LAKE ABOUT 10 MILES FROM THE SITE THAT IS CURRENTIY USED FOR FERRYING RAILCARS, ETC ON A DA ILY BASIS.

CURRENT CASK HANDLING CAPABILITIES :

Legal Truck: YES

Jverweight Truck: YES

Ra। l: NO

(a) Spent Fue! Storage Requirements, DOE/RL-84-1, May 1984.

(b) A indicates common pool shared by two reactors.

B indicates pools connected by transfer canal.

Cindicates pools connected by cask transfer.

(c) The distance from the operating deck to the bottom of the crane hook at its uppermost position.

(d) Refers to the respective usable dimension (i.e.. length, width, or depth) of the cask loading well. 
PLANT NAME: LA CROSSE

UTILITY: DAIRYLAND POWER COOPERATIVE

NEAREST TOWN: GENOA, WIS

NRC DOCKET NUMBER: $50-409$

REACTOR TYPE: BWR

RATING : ( a) $48 \mathrm{MWe}$

IN PLANT HANDLING PARAMETERS:

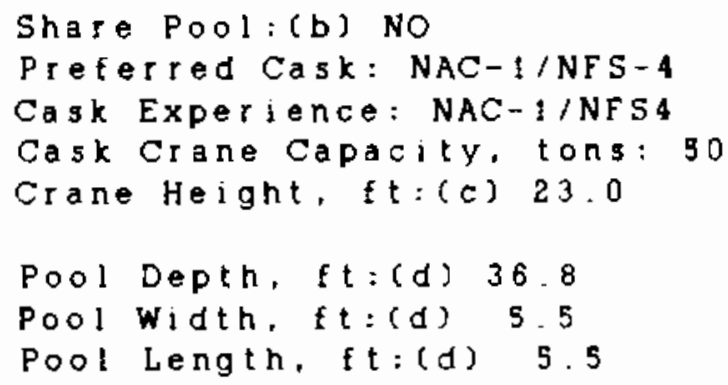

COMMENTS: NAC $\rightarrow$ I IS MAXIMUM SIZE CASX ABLE TO HANDLE, AND REACTOR MUST BE SHUT DOWN FOR ITS USE BECAUSE BOTH AIRLOCK DOORS MUST BE OPEN (AIRLOCK IS 15. LONG). WITH NAC-1, HAD TO BEGIN LIFTING CASK INTO UPRIGHT POSITION BEFORE IT WAS COMPLETELY OUT OF AIRLOCK.

RAIL/BARGE ACCESS DATA :

Ral 1 Spur on Site: NO

Nearest r a i l road: BURLINGTON NORTHERN

Distance from Rail Spur to Cask Loading Bay: 0 miles

Source of cooling water:

Barge Feasibility: YES

COMMENTS: RAILSPUR HASN'T BEEN USED FOR SEVERAL YEARS, AND MOST RAILCASKS WOULD BE TOO LARGE FOR FACILITY ANYWAY. FREQUENTLY USE BARGE FACILITIES FOR COAL SHIPMENTS

CURRENT CASK HANDLING CAPABILITIES:

Legal Truck: YES

Overweight Truck: NO

Rai!: NO

(a) Spent Fuel Storage Requirements, DOE/RL-84-1, May 1984.

(b) A indicates common pool shared by two reactors.

B indicates pools connected by transfer canal.

$C$ indicates pools connected by cask transfer.

(c) The distance from the operating deck to the bottom of the crane hook at its uppermost position.

(d) Refers to the respective usable dimension bl.e., length, width, or depthl of the cask loading well. 
PLANT NAME: LA SALLE-1

UTILITY: COMMONWEALTH EDISON COMPANY

NEAREST TOWN: SENECA, ILL

NRC DOCKET NUMBER: $50-373$

REACTOR TYPE: BWR

RATING: (a) $1030 \mathrm{MWe}$

\section{IN PLANT HANDLING PARAMETERS}

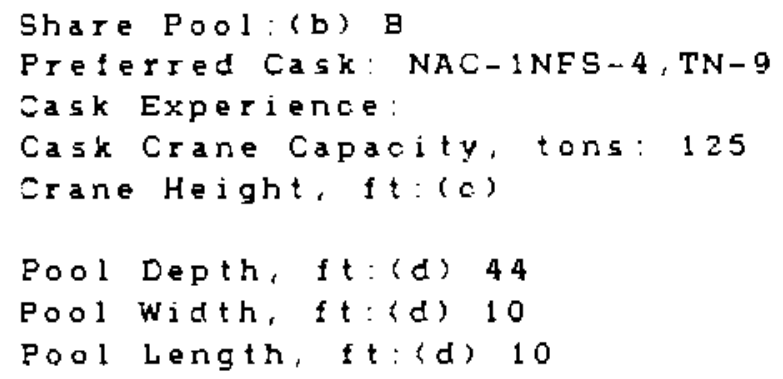

RAIL/BARGE ACCESS DATA:

Rail Gpur on Site: YES

Nearest railroad: ATCHISON, TOPEKA, SANTA FE

Distance from Rail Spur to Cask Loading Bay: 0 miles Source of cooling water: RESERVOIR

Barge Feasibility: YES

COMMENTS

\section{CURRENT CASK HANDLING CAPABILITIES}

Legal Truck: YES

Overweight Truck: YES

Rail: YES

\footnotetext{
(a) Spent Fuel Storage Requirements, DOE/RL-84-1, May 1984

(b) A indicates common pool shared by two reactors

9 indicates pools connected by transfer canal

$c$ indicates pools connected by cask transfer

(c) The distance from the operating deck to the bottom of the crane hook at its uppermost position

(d) Refers to the respective usable dimension (i.e., length, width, or depth) of the cask loading well
} 
PLANT NAME: LA SALLE-2

UTILITY: COMMONWEALTH EDISON COMPANY

NEAREST TOWN: SENECA, ILL

NRC DOCKET NUMEER: $50-374$

REACTOR TYPE: BWR

RATING: (a) 1090 MWE

IN PLANT HANDLING PARAMETERS

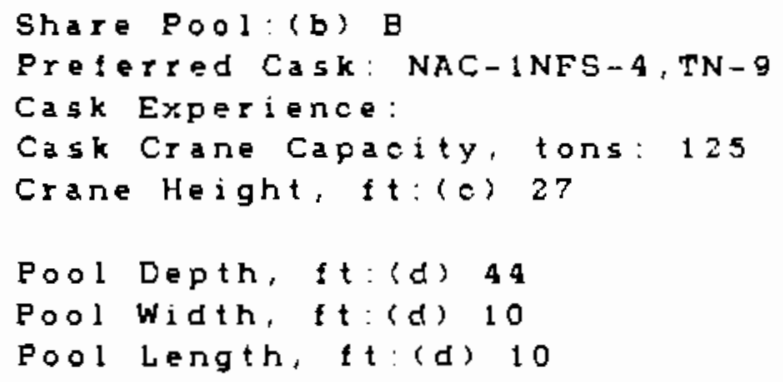

RAIL/BARGE ACCESS DATA

Rail Spur on Site: YES

Nearest railroad: ATCHISON, TOPEKA, SANTA FE

Distance from Rail Spur to Cask loading Bay: 0 miles

Source of cooling water: RESERVOIR

Barge Feasibility: YES

COMMENTS:

\section{CURRENT CASK HANDLING CAPABILITIES}

Legal Truok: YES

Overweight Truck: YES

Rail: YES

\footnotetext{
(a) Spent Fuel Storage Requirements, DOE/RL-84-1, May 1994

(b) A indicates common pool shared by two reactors

B indicates pools connected by transfer canal

$c$ indicates pools connected by cask transfer

(c) The distance from the operating deck to the bottom of the crane hook at its uppermost position

(d) Refers to the respective usable dimension (i. e, length, width, or depth) of the cask loading well
} 
PLANT NAME : LIMER I CK - 1

UTILITY: PHILADELPHIA ELECTRIC COMPANY

NEAREST TOWN: POTTSTOWN, PA

NRC DOCKET NUMBER: $50-352$

REACTOR TYPE : BWR

RATING : (a) 1100 MWe

IN PLANT HANDLING PARAMETERS:

Share Pool:(b) $C$

Preferred Cask: NONE SPECIFIED

Wask Experience: NONE

Jask Crane Capacity, tons: 110

Zrane Height, $f t:(c) 31.0$

Pool Depth, ft:(d) 42.0

Pool Width, ft: (d) 9.0

Pool Length, $f t:(d) 14.0$

COMMENTS: 125 TON MAIN HOOK FOR CRANE, BUT MAXIMUM LIFT FOR CRITICAL LOADING (ACCOUNTING FOR DYNAMIC WEIGHT) IS 110 TON. FLOOR LOADING LIMITS ARE 1000 LBS PER SQUARE FOOT.

\section{RA!L/BARGE ACCESS DATA:}

Qail Spur on Site: YES

Nearest rail road: CONRAIL

Jistance from Rall Spur to Cask Loding Bay: 0 miles

Source of cooling water: SCHUYLKILL RIVER

Barge Feasibility: NO

COMMENTS: SCHUYLKILL RIVER IS TOO SHALLOW IN NEAREST PART TO BRING IN A BARGE. IF THEY ARE TO DO ANY XIND OF CASK HANDLING, $95 \%$ CERTAIN THEY WOULD $5 H I P$ BY RAIL; LINE IS OPERATING AND IN GOOD SHAPE.

CURRENT CASK HANDLING CAPABILITIES:

Legal Truck: YES

Overweight Truck: YES

Rai 1: YES

(a) Spent Fuel Storage Requirements, DOE/RL-84-1. May 1984 .

(b) A indicateg common pool shared by two reactors.

B indicates pools connected by transfer canal.

$\approx$ indicates pools connected by cask trangfer

(c) The distance from the operating deck to the bottom of the crane hook at its uppermost position.

(d) Refers to the respective usable dimension (a. e., length, width, or depth) of the cask loading well. 
PLANT NAME : LIMER ICK -2

UTILITY: PHILADELPHIA ELECTRIC COMPANY

NEAREST TOWN : POTTSTOWN, PA

NRC DOCKET NUMBER: $50-353$

REACTOR TYPE : BWR

RAT ING : (a) 1100 MWe

IN PLANT HANDLING PARAMETERS:

Share Pool: (b) C

Preferred Cask: NO

Cask Experience: NONE

Cask Crane Capacity, tons: 110*

Crane Height, $f t:(c) 31.0$

Pool Depth, Et:(d) 42.0

Pool Width, ft:(d) 9.0

Pool Length, ft: (d) 14.0

COMMENTS: LIMERICK 1 AND LIMERICK 2 HAVE SEPARATE AREAS FOR SETTING CASKS THAT ARE OF IDENTICAL DIMENSIONS.

A TRANSFER CANAL CONNECTS THE POOLS, AND THE CRANE IS SHARED. SEE COMMENTS; LIMERIICK-I

\section{RAIL/BARGE ACCESS DATA:}

Rail Spur on Site: YES

Nearest railroad: CONRAlL

Distance from Rall Spur to Cask Loading Bay: 0 miles

Source of coo!ing water: SCHUYLKILL RIVER

Barge Feasibility: NO

COMMENTS: SEE COMMENTS; LIMERICK-1.

CURRENT CASK HANDLING CAPABILITIES:

Lega I Truek: YES

Overweight Truck: YES

Ra I 1 : YES

(a) Spent Fuel Storage Requirements, DOE/RL-84-1, May 1984

(b) A indicates common pool shared by two reactors.

B indicates pools connected by trangfer canal.

C indicates pools connected by cask transfer.

(c) The distance from the operating deck to the bot om of the crane hook at its uppermost position.

(d) Refers to the respective usable dimension (i.e., length, width. or depth) of the cask loading well. 
PLANT NAME: MAINE YANKEE

UTILITY: MAINE YANKEE ATOMIC POWER COMPANY

NEAREST TOWN: WISCASSET, ME

NRC DOCKET NUMBER: $50-309$

REACTOR TYPE: PWR

RATING: (a) B10 MWe

\section{IN PLANT HANDLING PARAMETERS:}

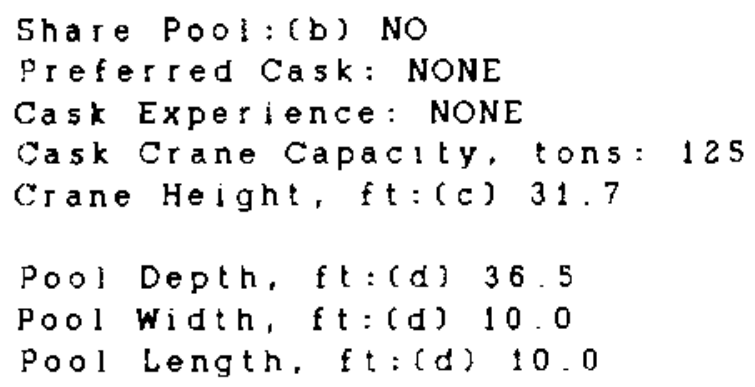

COMMENTS: NOT LICENSED TO USE A CASK. TECH SPEC PROHIBITS LICENSING SPENT FUEL CASK UNTIL CASK DROP ACCIDENT ANALYZED NO SERIOUS CONSIDERATION OF CASK TYPE AT THIS TIME

RA1L/BARGE ACCESS DATA:

Rail Spur on 5ite: YES

Nearest railroad: MAIN CENTRAL,

Distance from Rail Spur to Cask Loading Bay: 0 miles jource of cooling wate BACK RIVER

Barge Feasibility: YES

COMMENTS: NO DOCK, BUT LARGER COMPONENTS WERE BROUGHT IN BY BARGE UP BACK RIVER DURING CONSTRUCTION. RIVER USE OPTION CONCEIVABLE. RAIL TRACKS THERE BUT NEVER USED.

CURREVT CASK HANDLING CAPABILITIES:

segal Truck: YES

Juerweight Truck: YES

ina l : YES

(a) jpent Fuel Storage Requirements, DOE/RL-84-1, May 1984.

(b) A indlcates common pool shared by two reactors.

$B$ indicates pools connected by transfer canal.

Q indicates pools connected by cask transfer.

(c) The distance from the operating deck to the bottom of the crane hook at its uppermost position.

(d) Refers to the respective usable dimension (i.e.. length. width, or depthl of the cask loading well. 
PLAN'T NAME: MARBLE HILL-1

UT ILITY: PUBLIC SERVICE COMPANY OF INDIANA

NEAREST TOWN : JEFFERSON COUNTY, IN

NRC DOCKET NUMBER: $\mathbf{5 0 - 5 4 6}$

REACTOR TYPE: PWR

RATING : (a) $111 \mathrm{~S}$ MWe

IN PLANT HANDLING PARAMETERS:

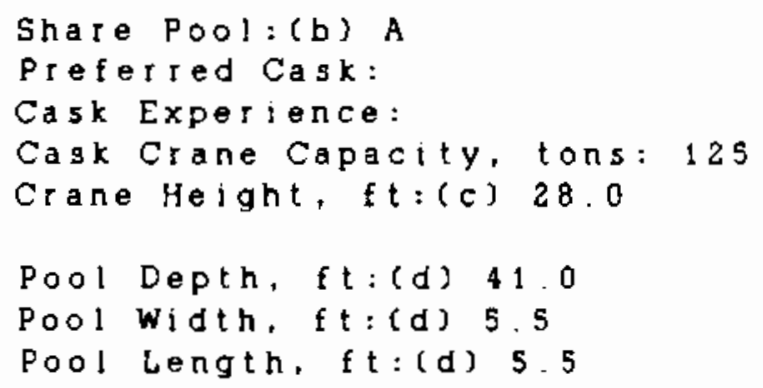

COMMENTS :

RAIL/BARGE ACCESS DATA:

Rail Spur on Site: YES

Nearest rail road: CHESAPEAKE AND OHIO

Distance from Rail Spur to Cask Loading Bay: 0 miles

Source of cooling water: OHIO RJVER

Barge Feasibility: YES

COMMENTS: RAIL LIMIT IS 100 TONS ON STANDARD RAILROAD CAR WITH 4 AXLES.

CURRENT CASK HANDLING CAPABILITIES:

Legal Truck: YES

Overwe ight Truck: NO

Rail l: YES

(a) Spent fuel Storage Requirements, DOE/RL-84-1, May 1984 .

(b) A indicates common pool shared by two reactors.

B indicates pools connected by transfer canal

C indicates pools connected by cask transfer.

(c) The distance from the operating deck to the bottom of the crane hook at its uppermost position.

(d) Refers to the respective usable dimension (1.e., length, width. Or depth) of the cask loading well. 
PLANT NAME: MARBLE H1LL-2

UTILITY: PUBLIC SERVICE COMPANY OF INDIANA

NEAREST TOWN: JEFFERSON COUNTY, IN

NRC DOCXET NUMBER: $50-547$

REACTOR TYPE: PWR

RATING: (a) $1115 \mathrm{MWe}$

IN PLANT HANDLING PARAMETERS:

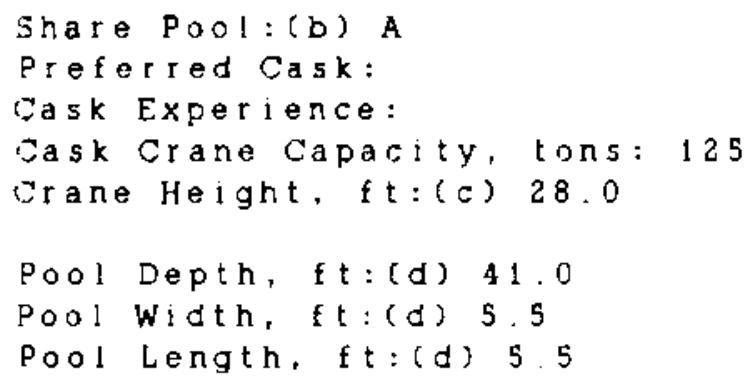

COMMENTS: SEE COMMENTS: MARBLE HILL-1.

RAIL/BARGE ACCESS DATA:

Rail Spur on Site: YES

Nearest ral!road: CHESAPEAKE AND OHIO

Jistance from Rail Spur to Cask Loading Bay: 0 miles

Source of cooling water: OHlO RlVER

Barge Feasibility: YES

COMMENTS: SEE COMMENTS; MARELE HILL-1

\section{CURRENT CASK HANDLING CAPABILITIES:}

Legal Truck: YES

Dverwelght Truck: NO

Rai!: YES

(a) Jpent Fuel storage Requirements, DOE/RL-84-1, May 1994.

(b) 4 indicates common pool shared by two reactors.

B indicates pools connected by transfer canal.

2 Indicates pools connected by cask transter.

(c) The distance from the operating deck to the bottom of tho arane hook at its uppermost position.

(d) Refers to the respective usable dimension li.e. length. width, or depthl of the cask loading well 
PLANT NAME: MCQU!RE-!

UTILITY: DUKE POWER COMPANY

NEAREST TOWN : CORNELIUS, SC

NRC DOCKET NUMBER: 50-369

REACTOR TYPE: PWR

RAT ING : (a) 1180 MWe

IN PLANT HANDLING PARAMETERS:

Share Pool:(b) ?

Preferred Cask: TRUCK

Cask Experience: NLI $1 / 2$

Cask Crane Capacity, tons: 125

Crane Height, ft:(c) 26.2

Pool Depth, ft: (d) 48.4

Pool Width, Et:(d) 9.1

Pool Length, $f t:(d) 11.1$

COMMENTS :

RAIL/BARGE ACCESS DATA:

Rail Spur on Site: YES

Nearest rail road: SOUTHERN

Distance from Rail Spur to Cask Loading Bay; 0 miles Source of cooling water: LAKE NORMAN

Barge Feasibility: No

COMMENTS :

CURRENT CASK HANDLING CAPABILITIES:

Legal Truck: YES

Overweight Truck: YES

Rail: YES

(a) Spent Fuel Storage Requirements, DOE/RL-84-1, May 1984

(b) A indicates common pool shared by two reactors.

B indicates pools connected by transfer cana!.

C indicates pools connected by cask transfer.

(c) The distance from the operating deck to the bottom of the crane hook at its uppermost position.

(d) Refers to the respective usable dimension (1, e, length. width, or depthl of the cask loading well. 
PLANT NAME: MC GUIRE-2

UTILITY: DUKE POWER COMPANY

NEAREST TOWN: CORNELIUS, SC

NRC DOCKET NUMBER: $50-370$

REACTOR TYPE: PWR

RATING : (a) $1180 \mathrm{MWe}$

\section{IN PLANT HANDLING PARAMETERS:}

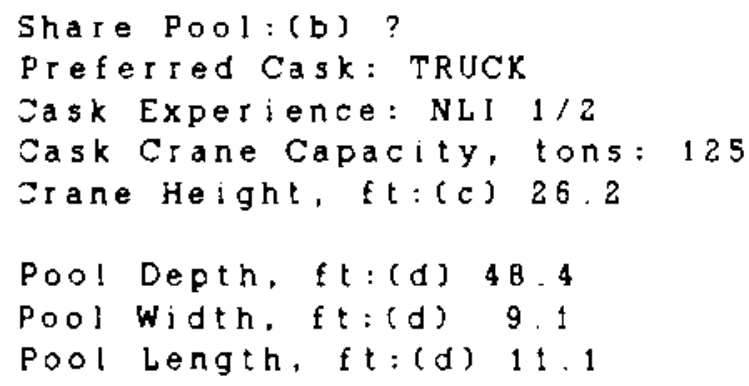

COMMENTS :

RAIL/BARGE ACCESS DATA:

Rail Spur on Site: YES

Nearest rall road: SOUTHERN

Distance from Rail Spur to Cask Loading fay: 0 miles Source of cooling water: LAKE NORMAN

Barge Feasibility: NO

COMMENTS :

CURRENT CASK HANDLING CAPABILITIES:

Legal Truck: YES

Overweight Truck: YES

Rail : YES

(a) Spent Fuel Storage Requirement5, DOE/RL-84-1, May 1984.

(b) A indicates common pool shared by two reactors.

B indicates pools connected by transfer canal.

Z indicates pools connected by cask transfer.

(c) The distance from the operating deck to the bottom of the crane hook at its uppermost posttion.

(d) Refers to the respective usable dimension (1.e... length, width, or depth) of the cask loading well 
PLANT NAME: MILLSTONE-1

UTILITY: NORTHEAST UTILITIES

NEAREST TOWN : WATERFORD, CONN

NRC DOCKET NUMBER: $50-245$

REACTOR TYPE: BWR

RATING: (a) 652 MWe

IN PLANT HANDLING PARAMETERS:

Share Pool: (b) NO

Preferred Cask: NONE SPECIFIED

Cask Experience:

Cask Crane Capacity, tons: 110

Crane Height, f $t:(c) 22$

Pool Depth, ft: (d) 38.8

Pool Width, ft:(d) 7.3

Pool Length, ft:(d) 7.3

COMMENTS: THE SPENT FUEL POOL HAS NO CASK 'WELL'. A 53 5Q. FT AREA IS SET ASIDE IN THE SPENT FUEL POOL FOR CASK HANDLING OPERATIONS. INTERLOCKING ACCESS DOORS MUST BE CLQSED DURING CASK OFERATIONS.

RAIL/BARGE ACCESS DATA:

Rail Spur on Site: YES

Nearest railroad: CONRAl L

Distance from Rail Spur to Cask Loading Bay: 0 miles

Source of cooling water: LONG ISLAND SOUND/A. OCEAN

Barge Feasibility: YES

COMMENTS :

CURRENT CASK HANDLING CAPABILITIES:

Lega! Truck: YES

Overweight Truck: YES

Rail: YES

(a) Spent Fuel starage Requirements, DOE/RL-84-1, May 1984

(b) A indicates common pool shared by two reactors.

B indicates paols connected by transter canal.

$C$ indicates pools cannected by cask transfer.

(c) The distance from the operating deck to the bottom of the crane hook at its uppermost pasition.

(d) Referg to the respectlve usable dimension (i.e... length. width, or depth) of the cask loading well. 
PLANT NAME : MILLSTONE -2

UTILITY: NORTHEAST UTILITIES

NEAREST TOWN : WATERFORD, CONN

NRC DOCKET NUMBER: $50-336$

REACTOR TYPE : PWR

RATING:(a) $864 \mathrm{MWe}$

IN PLANT HANDLING PARAMETERS:

Share Pool: (b) NO

Preferred Cask: NONE SPECIFIED

Cask Experience:

Sask Crane Capacity, tons: 100

Crane Height, $f t:(c) 25$

Pool Depth, ft:(d) 38.5

Pool Width. f $t:(d) \quad g$

Pool Length, $f t:(d) \quad g$

COMMENTS: THE ACCESS DOORS MUST BE CLOSED DURING CASK OPERATIONS.

RAIL/BARGE ACCESS DATA:

Rail Spur on Site: YES

Nearest rail road: CONRAIL

Distance from Rail Spur to Cask Loading Bay: 0 miles

Source of cooling water: LONG ISLAND SOUND/A. OCEAN

Barge Feasibility: YES

COMMENTS :

CURRENT CASK HANDLING CAPABILITIES:

iegai Truck: YES

Overweight Truck: YES

रai 1: YES

(a) jpent Fuel storage Requirements, DOE/RL-B4-1, May 1984.

(b) A indicates common pool shared by two reactors.

3 indicates pools connected by transfer canal.

$\checkmark$ indicates pools connected by cask transfer.

(c) The distance from the operating deck to the bottom of the srane hook at its uppermost position.

(d) Refers to the respective usable dimension li.e., length, width, or depth) of the cask loading well. 
PLANT NAME : MILLSTONE-3

UTILITY: NORTHEAST UTILITIES

NEAREST TOWN : WATERFORD, CONN

NRC DOCKET NUMBER : $50-423$

REACTOR TYPE: PWR

RATING : (Q) 1150 MWe

IN PLANT HANDLING PARAMETERS:

Share Pool: (b) NO

Preferred Cask:

Cask Experience:

Cask Crane Capacity, tons: 100

Crane Height, $f t:(c)$

Pool Depth, tt:(d)

Pool Width, ft: (d)

Pool Length, $t \mathrm{t}:(d)$

COMMENTS :

RAIL/BARGE ACCESS DATA:

Rail Spur on Site: YES

Nearest ra il road: CONRAlL

Distance from Rail Spur to Cask Loading Bay: 0 miles Source of cooling ater: LONG Is. SOUND/ATLANTIC O

Barge Feasibility:

COMMENTS :

CURRENT CASK HANDLING CAPABILITIES:

Legal Truck: YES

Overweight Truck: YES

Rai ! : YES

(a) Spent Fuel Storage Requirements, DOE/RL-84-1. May 1984

(b) A indicates common pool shared by two reactors.

$B$ indicates pools connected by transfer canal.

C indicates pools connected by cask transfer.

(c) The distance from the operating deck to the bot om of the crane hook at its uppermost position.

(d) Refers to the respective usable dimension (i.e.. length, width, or depthl of the cask loading well. 
PLANT NAME: MONTICELLO

UTILITY: NORTHERN STATES POWER COMPANY

NEAREST TOWN: MONTICELLO, MINN

NRC DOCKET NUMEER: $50-263$

REACTOR TYPE: QWR

RATING:\{a\} $525 \mathrm{MWe}$

IN PLANT HANDLING PARAMETERS:

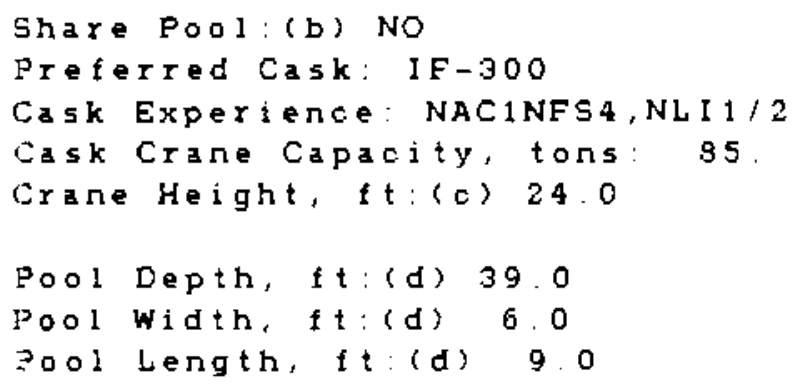

RAIL/BARGE ACCESS DATA:

Rail Spur on Site: YES

Nearest railroad: BURLINGTON NORTHERN

Distance from Rajl Spur to Cask loading Bay: 0 miles

Source of cooling water: MISSISSIPPI RIVER

Barge Feasibility: NO

COMMENTS :

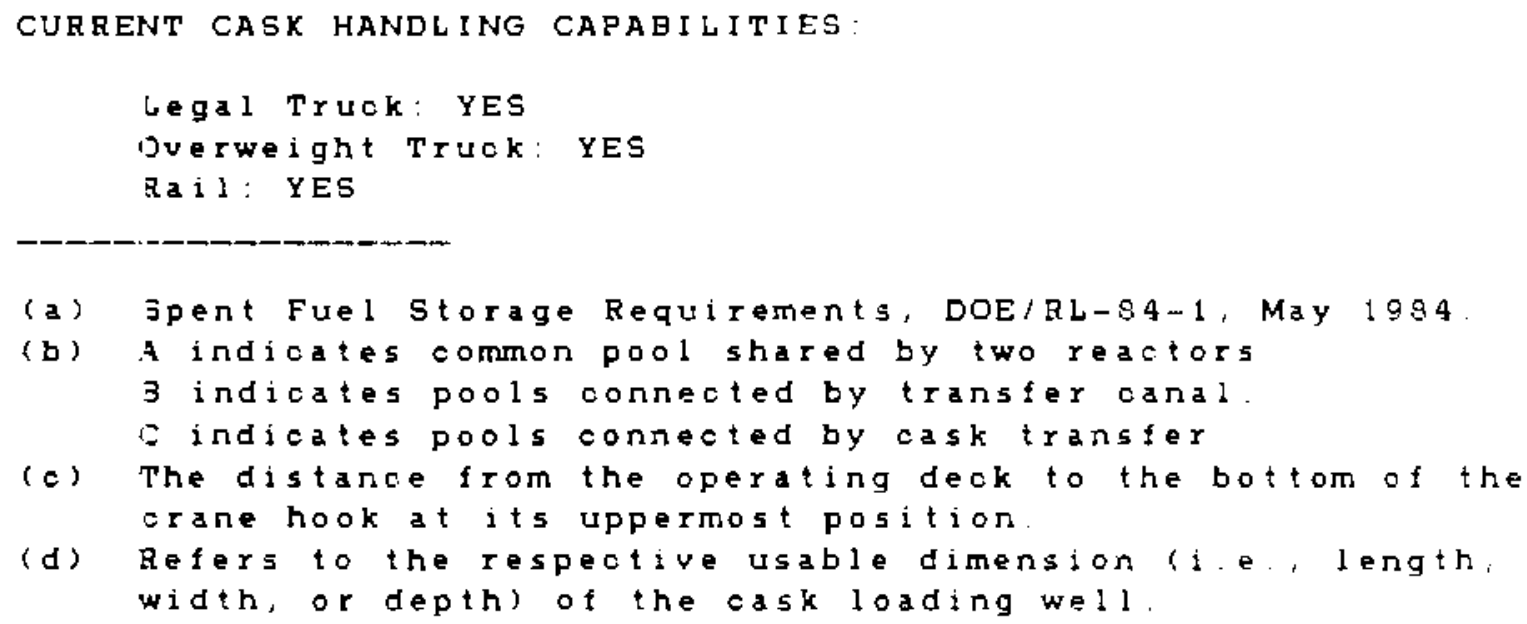

(a) Jpent Fuel Storage Requirements, DOE/RL-84-1, May 1994

(b) A indicates common pool shared by two reactors

3 indicates pools connected by transfer canal.

E indicates pools connected by cask transfer

(c) The distance from the operating deck to the bottom of the crane hook at its uppermost position.

(d) Refers to the respective usable dimension (i.e., length; width, or depth) of the cask loading well. 
PLANT NAME: NINE MILE POINT-1

UTILITY: NIAGARA MOHAWK POWER CORPORATION

NEAREST TOWN : SCRIBA, NY

NRC DOCKET NUMBER: $50-220$

REACTOR TYPE: BWR

RATING : (a) $610 \mathrm{MWe}$

IN PLANT HANDLING PARAMETERS :

Share Pool: (b) NO

Preferted Cask: NONE

Cask Experience: NONE

Cask Crane Capacity, tons: 125

Crane Height, f $t:$ (c) 24.5

Pool Depth, ft:(d) 38.3

Pool Width, ft: (d) 9.2

Pool Length, ft:(d) 9.2

COMMENTS: ALL SPENT FUEL TO DATE IS ON-SITE. FSAR MENTIONED

$7.0^{\prime} X 7.0^{\circ}$ STRIKER PLATE THAT COULD LIMIT WHERE

CASK CAN. BE SET ON FLOOR. INSIDE DIAMETER OF CASK

LOADING WELL IS $110.5 "$.

RAIL/BARGE ACCESS DATA:

Rail Spur on Site: YES

Nearest rail road: CONRAIL

Distance from Rail Spur to Cask Loading Bay: 0 miles

Source of cooling water: LAKE ONTARIO

Barge Feasibi! ity: YES

COMMENTS: LIMITATIONS ON ACCESS ROADS. NO DOCK

CURRENT CASK HANDLING CAPABILITIES:

Legal Truck: YES

Overweight Truck: YES

Ra1!: YES

(a) Spent Fuel Storage Requirements, DOE/RL-84-1, May 1984

(b) A indicates common pool shared by two reactors.

B indlcates pools connected by transter canal.

$C$ indicates pools connected by cask transfer.

(c) The distance from the operating deck to the bottom of the crane hook at 1 ts uppermost position.

(d) Refers to the respective usable dimension (i.e., length, width, or depthu of the cask loading well. 
PLANT NAME : NINE MILE POINT-2

UTILITY: NIAGARA MOHAWK POWER CORPORATION

NEAREST TOWN : SCRIBA, NY

NRC DOCKET NUMBER: $50-410$

REACTOR TYPE : BWR

RAT ING : (a) $1080 \mathrm{MWe}$

\section{IN PLANT HANDLING PARAMETERS:}

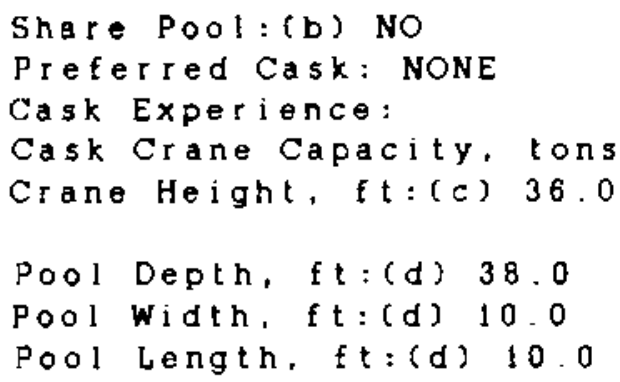

COMMENTS: CASK LOADING WELL IS CYLINDIRICAL, WITH A 10 FOOT I NSIDE DIAMETER.

RAIL/BARGE ACCESS DATA:

Rail Spur on Site: YES

Nearest rail road: CONRAIL

Distance from Rail Spur to Cask Loading Bay: 0 miles jource of coo! ing water: LAKE ONTARIO

Barge Feasibility: YES

COMMENTS: SEE COMMENTS; NINE MILE POINT-1.

CURRENT CASK HANDLING CAPABILITIES:

Legal Truck: YES

Overweight Truck: YES

२a i I: YES

(a) jpent fuel Storage Requirements, DOE/RL-B4-1, May 1984 .

(b) A indicates common pool shared by two reactors.

B indicates pools connected by transfer canal.

$C$ indicates pools connected by cask transfer.

(c) The distance from the operating deck to the bottom of the crane hook at its uppermost position.

(d) Refers to the respective ugable dimension (i.e... length. width, or depth) of the cask loading well.

\section{A. 70}


PLANT NAME: NORTH ANNA-1

UTILITY : VIRGINIA ELECTRIC POWER COMPANY

NEAREST TOWN : MINERAL, VA

NRC DOCKET NUMBER: $50-338$

REACTOR TYPE: PWR

RATING: (a) \&65 MWe

IN PLANT HANDLING PARAMETERS:

Share Pool:(b) A

Preferred Cask: TN9

Cask Experience: NONE

Cask Crane Capacity, tons: 125.

Crane Height, ft: (c) 29.0

Pool Depth, ft:(d) 45.0

Pool Width, ft: (d) 12.0

Pool Length, $t t:(d) 12.0$

COMMENTS: LICENSEE KNOWS AN 18' HIGH CASK (THE TN-g) CAN BE HANDLED.

RAIL/BARGE ACCESS DATA:

Rail Spur on Site: YES

Nearest rail road: CHESAPEAKE AND OHIO

Distance from Rail spur to Cagk Loading Bay: 0 miles

Source of cooling water: LAKE ANNA

Barge Feasibility: NO

COMMENTS: TRACKS ARE ON-SITE AND THERE ARE PLANS FOR A RAILSPUR, BUT IT DOESN'T EXIST YET. LOCATED ON A LAKE, BUT NO BARGE ACCESS.

CURRENT CASK HANDLING CAPABILITIES :

Lega! Truck: YES

Overweight Truck: YES

Raj i: YES

(a) Spent Fuel Storage Requirements, DOE/RL-84-1, May 1984.

(b) A indicates common pool shared by two reactors.

B indicates pools connected by transfer canal.

C indicates pools connected by cask transfer.

(c) The distance from the operating deck to the bottom of the crane hook at its uppermost position.

(d) Refers to the respective usable dimension (i.e... length. width. or depthl of the cask loading well. 
PLANT NAME: NORTH ANNA-2

UTILITY: VIRGINIA ELECTRIC POWER COMPANY

NEAREST TOWN : MINERAL, VA

NRC DOCKET NUMBER : $50-339$

REACTOR TYPE: PWR

RAT ING : ( a ) $890 \mathrm{MWe}$

IN PLANT HANDLING PARAMETERS :

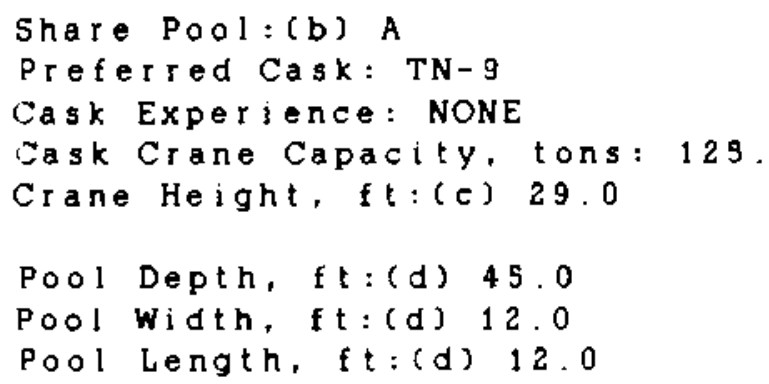

COMMENTS: SAME POOL FOR NORTH ANNA-1 AND NORTH ANNA-2

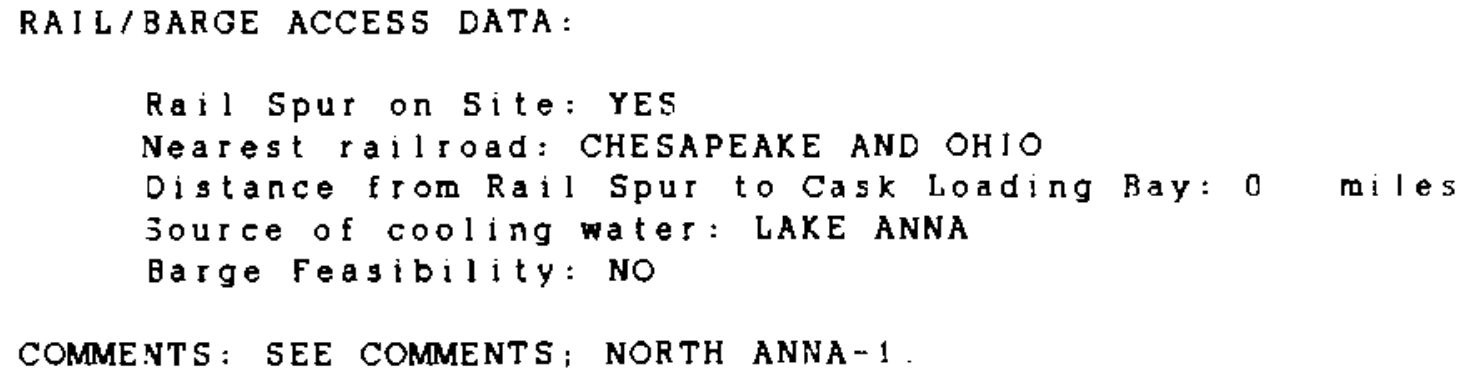

CURRENT CASK HANDLING CAPABILITIES:

Legal Truck: YES

Jverweight Truck: YES

Rai l: YES

(a) Spent Fuel Storage Requirements, DOE/RL-84-1, May 1984 .

(b) A indicates common pool shared by tro reactors.

B indicates pools connected by transter canal.

I indicates pools connected by cask transfer.

(c) The distance from the operating deck to the bottom of the crane hook at its uppermost position.

(d) Refers to the respective usable dimengion (i.e.. length. width, or depthj of the cask loading well

\section{A. 72}


PLANT NAME: OCONEE-1

UTILITY : DUKE POWER COMPANY

NEAREST TOWN: SENECA, SC

NRC DOCKET NUMBER: $50-269$

REACTOR TYPE: PWR

RATING: (a) $886 \mathrm{MWe}$

IN PLANT HANDLING PARAMETERS:

Share Pool:(b) NO

Preferred Cask: TRUCK

Cask Experience: NAC-1 \& NLI-1/2

Cask Crane Capacity, tons: 100

Crane Helght, ft: (c) 23.7

Poo! Depth, ft:(d) 44.0

Poo! Width, ft: (d) 7.1

Pool Length, f $t:(d)$ B.?

COMMENTS: CAN ONLY HANDLE SMALLER CASKS, IN ORDER TO USE AN OVERWEIGHT CASK THE PLANT WOULD NEED TO BE MODIFIED.

RAIL/BARGE ACCESS DATA:

Rail Spur on Sile: NO

Nearest railroad: SOUTHERN

Distance from Rail Spur to Cask Loading Bay: 10 miles

Source of cooling water: LARE KEOWEE

Barge Feasibility: NO

COMMENTS :

CURRENT CASK HANDLING CAPABILITIES:

Legal Truck: YES

Overweight Truck: NO

Rail: NO

(a) Spent Fuel Storage Requirements, DOE/RL-84-1, May 1984 .

(b) A indicates common pool shared by two reactors.

B indicates pools connected by transfer canal

C indicates pools connected by cask transfer.

(c) The distance from the operating deck to the bottom of the crane hook at its uppermost position

(d) Refers to the respective usable dimension (i.e., length, width, or depthl of the cask loading well. 
PLANT NAME : OCONEE-2

UTILITY: DUKE POWER COMPANY

NEAREST TOWN: SENECA, SC

NRC DOCKET NUMBER : $50-270$

REACTOR TYPE: PWR

RATING:(a) 886 MWe

IN PLANT HANDLING PARAMETERS:

Share Pool: (b) NO

Preferred Cask: NAC-1, NL $1-1 / 2$

Cask Experience: NAC-1, NLI-1/2

Zask Crane Capacity, tons: 100 .

Qrane Height, $f t:(c) 23.7$

Pool Depth, ft: (d) 44.0

Poo! Width, ft: (d) 7.1

Pool length, ft: (d) 8.7

COMMENTS: SEE COMMENTS; OCONEE-1

RAIL/BARGE ACCESS DATA:

Rail Spur on Site: NO

Nearest rail road: SOUTHERN

Distance from Rail Spur to Cask Loading Bay: 10 miles

source of cooling water: LAKE KEOWEE

Barge Feasibility: NO

COMMENTS: SEE COMMENTS; OCONEE-1

CURRENT CASK HANDLING CAPABILITIES:

Legal Truck: YEs

Dverweight Truck: NO

$\mathrm{Rai}$ ! : NO

(a) Spent Fuel Storage Requirements, DOE/RL-84-1, May 1984.

(b) A indicates common pool shared by two reactors.

B indicates pools connected by transfer canal.

z indicates pools connected by cask transfer.

(c) The distance from the operating deck to the bot tom of the crane hook at its uppermost position.

(d) Refers to the respective usable dimension (j.e.. length, width, or depthj of the cask loading well.

\section{A. 74}


PLANT NAME: OCONEE- 3

UTILITY : DURE POWER COMPANY

NEAREST TOWN : SENECA, SC

NRC DOCKET NUMBER: $50-287$

REACTOR TYPE : PWR

RAT ING: (a) 886 MWe

IN PLANT HANDLING PARAMETERS:

Share Pool: (b) NO

Preferred Cask: TN-8

Cask Experience: NAC-1, NL1-1/2

Cask Crane Capacity, tons: 100.

Crane Height, $f t:(c) 23.8$

Pool Depth, f $t:(d) 44$

Pool Width, ft: (d) 7.2

Pool Length, ft: (d) 8.9

COMMENTS: THE LICENSEE JUDGES THE TN-8 CASK TO BE THE LARGEST SPENT FUEL CASK THAT COULD BE HANDLED AT THIS PLANT

RAIL/BARGE ACCES5 DATA :

Rail Spur on Site: No

Nearest railroad; SOUTHERN

Distance from Rail Spur to Cask Loading Bay: 10 miles Source of cooling water: LAKE KEOWEE

Barge Feasibility: NO

COMMENTS: SEE COMMENTS; OCONEE-1.

CURRENT CASK HANDLING CAPABILITIES:

Legal Truck: YES

Overweight Truck: YES

Ra1 1: NO

(a) Spent Fuel 5torage Requirements, DOE/Rl-84-1. May 1984.

(b) A indicates common pool shared by two reactors.

B indicates pools connected by transfer canal.

C indicates pools connected by cask transfer

(c) The distance from the operating deck to the bottom of the crane hook at its uppermost position.

(d) Referg to the respective usable dimension (i.e.. length, width, of depthl of the cask loading well. 
PLANT NAME: OYSTER CREEK

UT ILITY: JERSEY CENTRAL POWER AND LIGHT CO

NEAREST TOWN : FORKED RIVER, NJ

NRC DOCKET NUMBER: $50-219$

REACTOR TYPE : BWR

RATING: (a) $620 \mathrm{MWe}$

IN PLANT HANDLING PARAMETERS:

Share Pool: (b) NO

Preferred Cask: TN-9/NFS-4/NAC 1

Cask Experience: NAC-1 NFS-4

Wask Crane Capacity, tons: 100.

Qrane Height, $f t:(c) 24.0$

Pool Depth, ft: (d) 41.0

Pool Width, ft:(d) 12.4

Poot length, ft: (d) 12.4

COMMENTS: THE SPENT FUEL POOL HAS NO CASK 'WELL'. A 153 SQ. FT AREA IS SET ASIDE IN THE SFP FOR CASK HANDLING OPERATIONS. THE FACILITY ACCESS DOORS MUST BE CLOSED DURING CASK OPERATIONS.

RAIL/BARGE ACCESS DATA:

Rail Spur on Site: NO

Nearest rail road: CONRAIL

Distance from Rail Spur to Cask Loading Bay: 15 mileg

Source of cooling water: BARNAGET BAY

Barge Feasibility: YES

COMMENTS: THE RAILROAD SPUR HAS BEEN ABANDONED BY THE RAILROAD AND THE TRACKS HAVE BEEN REMOVED FROM THE AIRLOCK AND THE SITE PROPER.

CURRENT CASK HANDLING CAPABILITIES:

Legal Truck: YES

Jverweight Truck: YES

Rail : NO

(a) Spent fuel Storage Requirements, DOE/RL-84-1, May 1984

(b) A indicates common pool shared by two reactors.

B indicates pools connected by transfer canal.

Indicates pools connected by cask transfer.

(c) The distance from the operating deck to the bottom of the crane hook at its uppermost position.

(d) Refers to the respective usable dimension (1.e., length, width, or depthu of the cask loading well. 
PLANT NAME: PALISADES

UTILITY: CONSUMERS POWER COMPANY

NEAREST TOWN: SOUTH HAVEN, MICH.

NRC DOCKET NUMBER: $50-255$

REACTOR TYPE: PWR

RATING : (a) 740 MWe

IN PLANT HANDLING PARAMETERS :

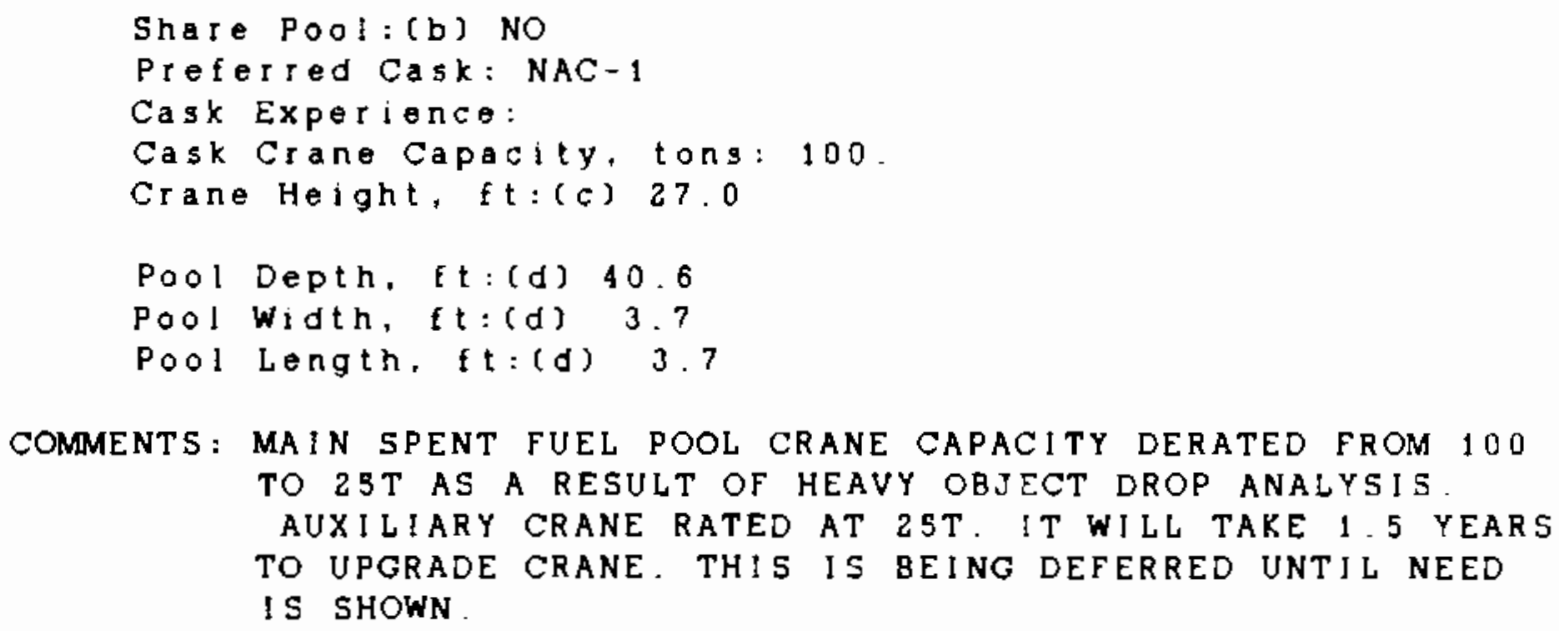

COMMENTS: MAIN SPENT FUEL POOL CRANE CAPACITY DERATED FROM 100 TO $25 T$ AS A RESULT OF HEAVY OBJECT DROP ANALYSIS. AUXILIARY CRANE RATED AT $25 T$. IT WILL TAKE 1.5 YEARS TO UPGRADE CRANE. THIS IS BEING DEFERRED UNTIL NEED IS SHOWN

RA I L / BARGE ACCESS DATA:

Rail Spur on Site: NO

Nearest rail road: CHESAPEAKE AND OHJO

Distance from Rail Spur to Cask Loading Bay: 0 miles

Source of cooling water: LAKE MICHIGAN

Barge Feasibility: YES

COMMENTS: RAIL SPUR INTO THE FUEL HANDLING BUILDING IS COVERED WITH ASPHALT. THEREFORE, THIS UNIT IS CONSIDERED NOT TO HAVE RAIL ACCESS, ALTHOUGH IT COULD BE DONE IF THE NEED AROSE.

CURRENT CASK HANDLING CAPABILITIES:

Legal Truck: YES

Overweight Truck: No

Rai 1: NO

(a) Spent Fuel 5 torage Requirements, DOE/RL-84-1, May 1984

(b) A indicates common pool shared by two reactors.

B indicates pools connected by transier cana!

C indicates pools connected by cask transfer.

(c) The distance from the operating deck to the bottom of the crane hook at its uppermost position

(d) Refers to the respective usable dimension (1.e... length, width. or depthl of the cask loading well. 
PLANT NAME : PALO VERDE - 1

UTILITY: ARIZONA PUBLIC SERVICF CO

NEAREST TOWN: WINTERSBURG, AR

NRC DOCKET NUMBER: $50-528$

REACTOR TYPE : PWR

RATING: (a) $1270 \mathrm{MWe}$

IN PLANT HANDLING PARAMETERS:

Share Pool: (b) NO

Preferred Cask: NONE

Cask Experlence: NONE

Cast Crane Capacity, tons: 150.

Crane Height, $f t:\{C\} 2 B .0$

Pool Depth, ft:(d) 45.0

Pool Width, ft: (d) 16.0

Pool Length, It: (d) 16,0

COMMENTS: UN!TS 1,2 \& 3 ARE IDENTICAL. OVERALL LENGTI OF FUEL ASSEMBLIES IS 178.25 INCHES, EXTRA LONG (COMBUSTION ENGINEER!NG SYSTEMS $80 "$ ).

RAIL/BARGE ACCESS DATA:

Rail Spur on Site: YES

Nearest rail road: SOUTHERN PACIFIC

Distance from Rail Spur to Cask Loading Bay: 0 miles

source of cooling water: RESERVOIR

Barge Feasibility: NO

COMMENTS: ALTHOUGH A RAIL SPUR EXTENDS INTO THE CASK LOADING BAY, DECISION HIAS BEEN MADE TO USE TRUCKS FOR CASK SHI PMENTS.

CURRENT CASK HANDLING CAPABILITIES:

Legal Truck: YES

Dverteight Truck: YES

Raj!: YES

(a) ipent Fuel Storage Requirements, DOE/RI,-84-1, May 1984

(b) A indicates common pool shared by two reactors.

3 indicates pals connected by transfer canal.

( indicates pools connected by cask transfer.

(c) Whe distance from the operating deck to the bottom of the iane hook at its uppermost position.

(d) Refers to the respective usable dimension (..... length, width, or depth) of the cask loading we!l. 
PLANT NAME : PALO VERDE-2

UTILITY: ARIZONA PUBLIC SERVICE CO.

NEAREST TOWN: WINTERSBURG, AR

NRC DOCKET NUMBER: $50-529$

REACTOR TYPE: PWR

RATING : (a) $1270 \mathrm{MWe}$

IN PLANT HANDLING PARAMETERS:

Share Pool: (b) NO

Preferred Cask: NONE

Cask Experience: NONE

Cask Crane Capacity, tons: 150 .

Crane Height, ft: (c) 28.0

Pool Depth, t t: (d) 45.0

Pool Width, ft: (d) 16.0

Pool Length, $f t:(d) 16.0$

COMMENTS : SEE COMMENTS; PALO VERDE-1.

RAIL/BARGE ACCESS DATA:

Rail Spur on Site: YES

Nearest railioad: SOUTHERN PACIFIC

Distance from Rail Spur to Cask Loading Bay: 0 miles

Source of cooling water: RESERVOIR

Barge Feasibility: NO

COMMENTS : SEE COMMENTS; PALO VERDE-1.

CURRENT CASK HANDLING CAPABILITIES:

Legal Truck: YES

Overweight Truck: YES

Rail: YES

(a) Spent Fuel Storage Requirements, DOE/RL-g4-1, May 1984.

(b) A indicates common pool shared by two reactors.

B indicates poals connected by transfer canal.

Cindicates pools connected by cask transfer.

(c) The distance from the operating deck to the bottom of the crane hook at its uppermost position.

(d) Refers to the respective usable dimension (i.e.. length. width, or depth of the cask loading well. 
PLANT NAME : PALO VERDE-3

UTILITY: ARIZONA PUBLIC SERVICE CO

NEAREST TOWN : WINTERSUBRG, AR

NRC DOCKET NUMBER: 50-530

REACTOR TYPE : PWR

RAT ING : (a) $1270 \mathrm{MWe}$

IN PLANT HANDLING PARAMETERS:

Share Pool: (b) NO

Preferred Cask: NONE

Cask Experience: NONE

Cask Crane Capacity, tons: 150 .

Crane Height, $f t:(c) 28.0$

Pool Depth, ft:(d) 45.0

Pool width, ft: (d) 16.0

Pool Length, ft: (d) 16.0

COMMENTS: SEE COMMENTS; PALO VERDE- 1.

\section{RAIL/BARGE ACCESS DATA:}

Rasl Spur on Site: YES

Nearest railioad: SOUTHERN PACIFIC

[istance from Rail Spur to Cask Loading Bay: 0 miles

Source of cooling water: RESERVOIR

Earge Feasibility: No

COMMENTS: SEE COMMENTS; PALO VERDE- 1

CURRENT CASK HANDLING CAPABILITIES:

L.egal Truck: YES

C.verweight Truck: YES

Fa i l: YES

(a) Epent Fuel storage Requirements, DOE/RL-84-1, May 1984.

(b) A indicates common pool shared by two reactors.

$b$ indicates pools connected by transfer canal.

$C$ indicates pools connected by cask transfer.

(c) The distance from the operating dect to the bottom of the crane hook at its uppermost position.

(d) Refers to the respective usable dimension (1.e., length, width, or depth) of the cask loading well. 
PLANT NAME: PEACH BOTTOM-2

UTILITY: PHILADELPHIA ELECTRIC COMPANY

NEAREST TOWN: PEACH BOTTOM, PA

NRC DOCKET NUMBER: 50-277

REACTOR TYPE : BWR

RATING: (a) $1051 \mathrm{MWE}$

IN PLANT HANDLING PARAMETERS:

Share Pool: (b) No

Preferred Cask: NONE SPECIFIED

Cask Experience: NLI-1/2

Cask Crane Capacity, tons: 125

Crane Height, ft: (c) 32 .0

Pool Depth, ft: (d) 39.0

Pool width, $f t:(d) \quad 9.0$

Pool Length, ft: (d) 9.0

COMMENTS: A CAR PULLER IS USED TO MOVE CASK TRAILERS IN THE FUEL HANDLING FACILITY

RAIL/BARGE ACCESS DATA:

Rail Spur on Site: NO

Nearest rail road: CONRAIL

Distance from Rail Spur to Cask Loading Bay: 20 miles

Source of cooling water: SUSQUEHANNA RIVER

Barge Feasibility: NO

COMMENTS: THE LICENSEE STATES THE RAILROAD IS CURRENTLY NOT SUITABLE FOR USE.

CURRENT CASK HANDLING CAPABILITIES:

Legal Truck: YES

Overweight Truck: YES

Rai ! : NO

(a) Spent Fuel Storage Requirements, DOE/RL-84-1. May 1984.

(b) A indicates common pool shared by two reactors.

B indicates pools connected by transfet cenal.

C indicates pools connected by cask transfer.

(c) The distance from the operating deck to the bottom of the crane hook at its uppermost position.

(d) Refers to the respective usable dimenston (i.e., length. width, or depthl of the cask loading well.

\section{A. 81}


PLANT NAME : PEACH BOTTOM-3

UTILITY: PHILADELPHIA ELECTRIC COMPANY

NEAREST TOWN : PEACH BOTTOM, PA

NRC DOCKET NUMBER: $50-278$

REACTOR TYPE: BWR

RATING: (a) $1035 \mathrm{MWE}$

\section{IN PLANT HANDLING PARAMETERS :}

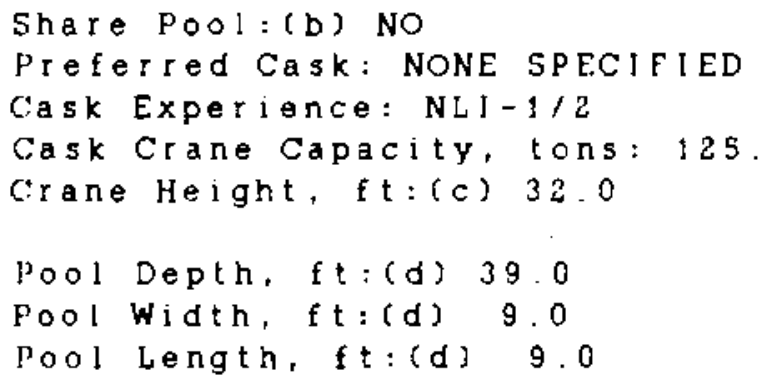

COMMENTS: SEE COMMENTS; PEACH BOTTOM-2

RAIL/BARGE ACCESS DATA:

Rail Spur on 5 ite: NO

Nearest rail road: CONRAIL

Distance from Rail Spur to Cask Loading Bay: 20 males Source of cooling water: SUSQUEHANNA RIVER

Barge Feasibl! ity: NO

COMMENTS: 5 EE COMMENTS; PEACH BOTTOM-2.

CURRENT CASK HANDLING CAPABILITIES:

l.egal Truek: YES

()verweight Truck: YES

Ra i l : NO

(a) ijpent Fuel Storage Requirements, DOE/RL-84+1, May 1984.

(b) $A$ indicates common pool shared by two reactors.

B indicates pools connected by transfer canal.

S: indicates pools connected by cask transfer.

(c) The distance from the operating deck to the bottom of the crane hook at its uppermost position.

(d) Refers to the respective usable dimension ( 1. e., length, widh, or depthl of the cask loading we!l.

\section{A. 82}


PLANT NAME: PERRY - 1

UTILITY: CLEVELAND ELECTRIC II,LUMINATING COMPANY

NEAREST TOWN : NORTH PERRY, OH

NRC DOCKET NUMBER: $50-440$

REACTOR TYPE : BWR

RATING : (a) $1205 \mathrm{MWe}$

IN PLANT HANDLING PARAMETERS:

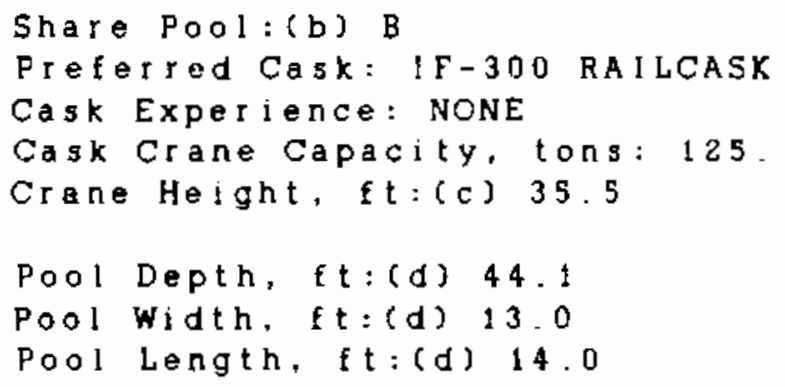

COMMENTS: HANDLING FACILITY DESIGN BASED UFON A $21^{\prime}$ LONG $10^{\prime}$ DIA. 125 TON CASK WITH 24-32 BWR ASSEMBLIES

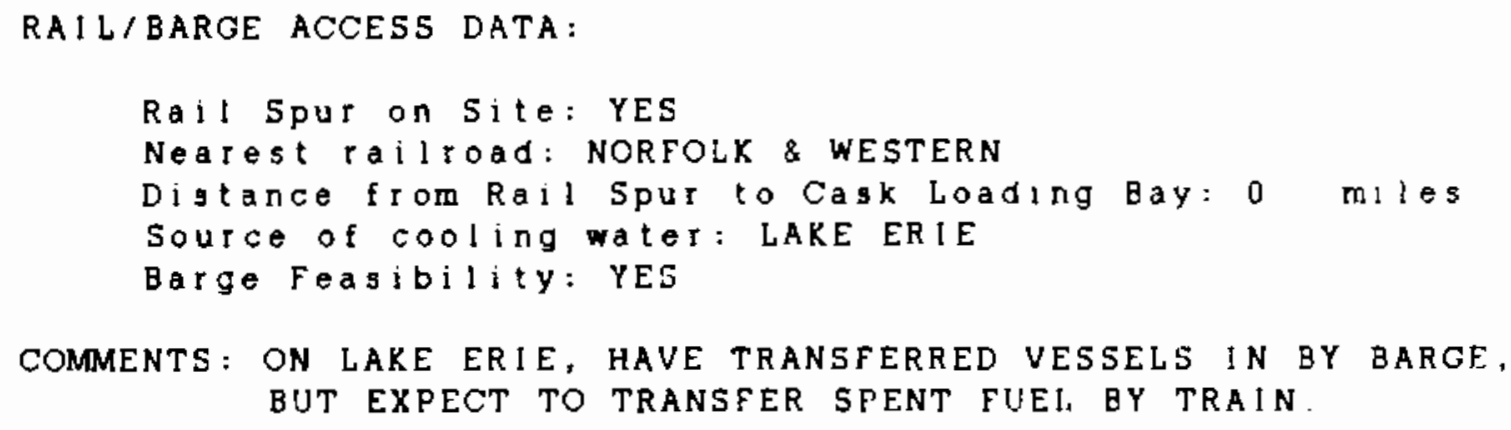

CURRENT CASK HANDLING CAPABILIT!ES:

Legal Truck: YES

Overweight Truck: YES

RE I : YES

(a) Spent Fuel Storage Requirements, DOE/RL-84-1, May 1984 .

(b) A indicates common pool shared by two resctors.

B indicates pools connected by transfer canal.

$C$ indicates pools connected by cask transfer.

(c) The distance from the operating deck to the bottom of the crane hook at its uppermost position.

(d) Refers to the respective usable dimension (i.e., length, width, or depth) of the cask loading well. 
PLANT NAME: PERRY-2

UTILITY: CLEVELAND ELECTRIC ILLUMINATINC COMPANY

NEAREST TOWN : NORTH PERRY, OH

NRC DOCKET NUMBER: SO-441

REACTOR TYPE: BWR

RATING: (a) $1205 \mathrm{MWe}$

IN PLANT HANDLING PARAMETERS:

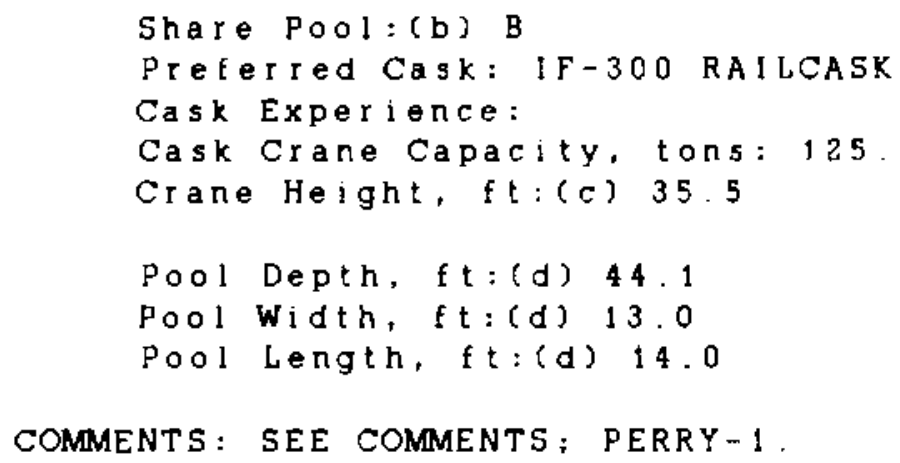

COMMENTS: SEE COMMENTS; PERRY-1.

RAIL/BARGE ACCESS DATA:

Rail Spur on Site: YES

Nearest rai ! road: NORFOLK \& WESTERN

Distance from Rail Spur to Cask Loading Bay: 0 miles source of cooling water: LARE ERIE

Barge Feasibility: YES

COMMENTS: SEE COMMENTS, PERRY-1.

CURRENT CASK HANDLING CAPABILITIES:

Legal Truck: YES

Overweight Truck: YES

₹ai l: YES

(a) Jpent Fuel Storage Requirements, DOE/RL-84-1, May 1984.

(b) A indicates common pool shared by two reactors.

3 indicates pools connected by transfer canal.

c indicates pools connected by cask transfer.

(c) The distance from the operating deck to the bottom of the irane hook at its uppermost position.

(d) Refers to the respective usable dimension (i.e., length, width, or depth) of the cask loading well. 
PLANT NAME : PILGRIM-1

UTILITY: BOSTON EDISON COMPANY

NEAREST TOWN : PLYMOUTH, MASS

NRC DOCKET NUMBER: $50-293$

REACTOR TYPE: BWR

RATING: (a) $670 \mathrm{MWe}$

IN PLANT HANDLING PARAMETERS:

Shaje Pool: (b) NO

Preferred Cask: NONE SPECIFIED

Cask Experience:

Cask Crane Capacity, tons: 100 .

Crane Height, $f t:(c) 23$.

Pool Depth, ft:(d) 39.0

Pool Width, ft:(d) 7.0

Pool Length, $f t:(d) 10.0$

COMMENT 5 :

RAIL/BARGE ACCESS DATA:

Rail Spur on 5ite: NO

Nearest rai! road: UNKNOWN

Distance from Rail Spur lo Cask Loading Bay: 25 miles

Source of cooling water: CAPE COD BAY

Barge Feasibility: YES

COMMENT5: PLANT IS ON A NAVIGABLE WATERWAY

CURRENT CASK HANDLING CAPABILITIES:

Legal Truck: YES

Overweight Truck: YES

Ra i 1: NO

(a) Spent Fuel Storage Requirements, DOE/RL-64-1, May 1984.

(b) A indicates common pool shared by two reactors.

B indicates pools connected by transfer canal.

C indicates pools connected by cask transfer.

(c) The distance from the operating deck to the bottom of the crane hook at its uppermost position.

(d) Refers to the respective usable dimension (i.e.. length, width, or depth) of the cask loading well. 
PLANT NAME: POINT BEACH-1

UTILITY: WISCONSIN ELECTRIC POWER COMPANY

NEAREST TOWN: TWO CREEKS, WIS

NRC DOCKET NUMBER: $50-266$

REACTOR TYPE: PWR

RATING : (a) $495 \mathrm{MWe}$

IN PLANT HANDLING PARAMETERS:

Share Pool: (b) A

Preferred Cask:

Cask Experience: NLI-1/2

Cask Crane Capacity, tons: $6 \mathrm{~S}$

Crane Height, ft: (c) 26.0

Pool Depth, ft:(d) 41.3

Pool Width, ft: (d) ?.8

Pool Length, $t: t:(d) \quad 8.2$

COMMENTS: CURRENTLY USING NLI-1/2. HAVE A 130 TON CRANE WHICH HAS BEEN DERATED TO 65 TONS. NEW 125 TON CRANE EXPECTED IN 1985. HAVE PERFORMED CASK DROP ANALYSIS ONLY FOR A 26 TON LWT CASK.

RAIL/BARGE ACCESS DATA:

Rail Spur on Site: No

Nearest railroad: GREEN BAY AND WESTERN

Distance from Rail Spur to Cask Loading Bay: 15 miles

Source of cooling ater: LAKE MICHIGAN

Barge Feasibility: YES

COMMENTS: NO EXISTING BARGE FACILITIES

CURRENT CASK HANDLING CAPABILITIES:

Legal Truck: YES

Overweight Truck: NO

Rai 1: NO

(a) Spent Fuel storage Requirements, DoE/RL-84-1, May 1984.

(b) A indicates common pool shared by two reactors

$B$ indicates poolg connected by transfer canal

C indicates pools connected by cask transfer.

(c) The distance from the operating deck to the bottom of the crane hook at its uppermost position.

(d) Refers to the respective usable dimension (s.e... Iength. width, or depth) of the cask loading well 
PLANT NAME: POINT BEACH-2

UTILITY: WISCONSIN ELECTRIC POWER COMPANY

NEAREST TOWN: TWO CREEKS, WIS

NRC DOCKET NUMBER: 50-301

REACTOR TYPE: PWR

RAT!NG: (a) 495 MWe

IN PLANT HANDLING PARAMETERS :

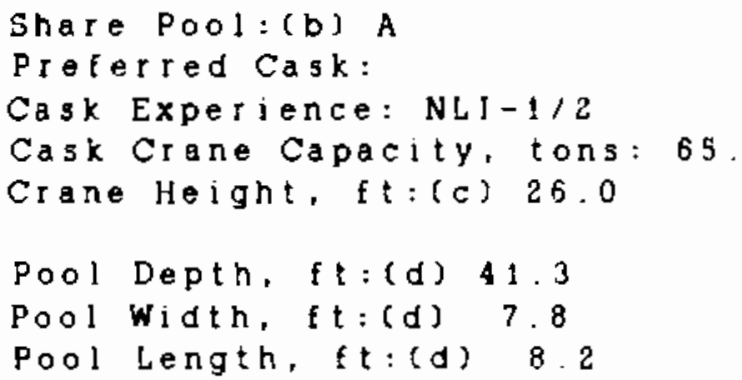

COMMENTS: SEE COMMENTS; POINT BEACH-1.

RAIL/BARGE ACCESS DATA:

Rail Spur on Site: No

Nearest rail rosd: GREEN BAY AND WESTERN

Distance from Rall Spur to Cask Loadıng Bay: 15 miles Source of cooling rater: LAKE MICHIGAN

Barge Feasibility: YES

COMMENTS: SEE COMMENTS; POINT BEACH-1.

CURRENT CASK HANDLING CAPABILITIES:

Legal Truck: YES

Overweight Truck: NO

Rai l: No

(a) Spent Fuel Storage Requirements, DOE/RL-84-1, May ig84

(b) A indicates common pool shared by two reactors.

B indicates pools connected by tiansfer canal

$C$ indicates pools connected by cask transfer

(c) The distance from the operating deck to the bottom of the crane hook at its uppermost position.

(d) Refers to the respective usable dimension (i.e., length, width, or depth) of the cask loading well. 
PLANT NAME: PRAIRIE ISLAND-1

UTILITY: NORTHERN STATES POWER COMPANY

NEAREST TOWN : RED WING, MINN

NRC DOCKET NUMBER: $50-282$

REACTOR TYPE: PWR

RAT ING: (a) $520 \mathrm{MWe}$

IN PLANT HANDLING PARAMETERS:

Share Pool: (b) A

Preferred Cask: NONE SPECIFIED

Cask Experience:

Cask Crane Capacity, tons: 125 .

Crane Height, $\mathrm{ft}:(\mathrm{c}) 36$.

Paol Depth, ft: (d) 41.5

Pool width, ft: (d) 12 .

Pool Length, ft: (d) 13 .

COMMENTS :

RAIL/BARGE ACCESS DATA:

Rail Spur on Site: YES

Nearest railroad: MILWAUKEE

Distance from Rail Spur ta Cask Loading Bay: 0 miles

Source of cooling water: MISSISSIPPI RIVER

日arge Feasibility: YES

COMMENTS: FROM MAR. 1 THROUGH APRIL 30, THERE ARE TRUCK PER AXLE WEIGHT RESTRICTIONS BECAUSE OF ROAD FROST-HEAVE CONCERNS.

CURRENT CASK HANDLING CAPABILITIES:

Jegal Truek: YES

Jverweight Truck: YES

Rail : YES

(a) Spent Fuel Storage Requirements, DOE/RL-84-1, May 1984 .

(b) A indicates common pool shared by two reactors.

B indicates pools connected by transfer canal.

C indicates pools connected by cask transfer.

(c) The distance from the operating deck to the bottom of the crane hook at its uppermost position

(d) Refers to the respective usable dimension (1.e., length. width, or depth) of the cask loading well.

\section{A. 88}


PLANT NAME : PRAIRIE ISLAND- 2

UTILITY : NORTHERN STATES POWER COMPANY

NEAREST TOWN : RED WING, MINN

NRC DOCKET NUMBER: $50-306$

REACTOR TYPE: PWR

RATING: (a) $520 \mathrm{MWe}$

IN PLANT HANDLING PARAMETERS:

Share Pool: (b) A

Preferred Cask: NONE SPECIFIED

Cask Experience:

Cask Crane Capacity, tons: 125 .

Crane Height, ft: (c) 36 .

Pool Depth, ft:(d) 41.5

Pool width, ft: (d) $t 2$.

Pool Length, f $t:(d) 13$.

COMMENTS :

RAIL/BARGE ACCESS DATA:

Rail Spur on Site: YES

Nearest railroad: M! LWAUKEE

Distance from Rail Spur ta Cask Loading Bay: 0 miles

Source of cooling water: MISSISSIPPI RIVER

Barge reasibility: YES

COMMENTS: SEE COMMENTS; PRA1RIE IJLAND-1.

CURRENT CASK HANDLING CAPABILITIES:

Legal Truck: YES

Overweight Truck: YES

Rail: YES

(a) Spent Fuel Storage Requirements, DOE/RL-84-1, May 1984

(b) A indicates common pool shared by too reactors.

B indicates pools connected by transier canal.

$C$ indicates pools connected by cask transfer.

(c) The distance from the operating deck to the bottom of the crane hook at its uppermost position

(d) Refers to the respective usable dimension (1.e... length. with, or depth of the cask loading well. 
PLANT NAME: QUAD CITIES-1

UTILITY: COMMONWEALTH EDISON COMPANY

NEAREST TOWN: CORDOVA, ILL

NRC DOCKET NUMBER: $50-254$

REACTOR TYPE: BWR

RAT ING : (a) $809 \mathrm{MWe}$

IN PLANT HANDLING PARAMETERS:

Share Pool: (b) B

Preferred Cask: TN-9

Cask Experience: NFS-4,NLI-1/2

Cask Crane Capacity, tons: 125 .

Crane Height, $f t:(c) 23.3$

Pool Depth, ft: (d) 38.8

Pool Width, ft: (d) 9.0

Pool Length, ft: (d) 9.0

COMMENTS: BELIEVED TO BE ABLE TO HANDLE IF-300 AND NLI-10/24 RAIL CASKS.

RAIL/BARGE ACCESS DATA:

Rail Spur on Site: YES

Nearest rail road: MILWAUKEE

Distance from Rail Spur to Cask Loading Bay: 0 miles

Source of cooling water: MISSISSIPPI RIVER

Barge Feasibilily: NO

COMMENTS: EVEN THOUGH THERE IS A RAILSPUR EXTENDING INTO THE CASK LOADING BAY, THE COMPANY IS NOT SET UP TO HANDIE A RAIL CASK AND WOULD ALMOST CERTAINLY USE A TRUCK CASK. MAXIMUM WT. ON CASK PAD IS 100 TONS.

CURRENT CASK HANDLING CAPABILITIES:

jegal Truck: YES

Jverweight Truck: YES

Rai 1: YES

(a) Spent Fuel Storage Requirements, DOE/RL-84-1, May 1984 .

(b) A indicates common pool shared by two reactors.

B indicates pools connected by transfer canal.

indicates pools connected by cask transfer

(c) The distance from the operating deck to the bottom of the crane hook at its uppermost position.

(d) Refers to the respective usable dimension (1.e., length, wdth, or depthl of the cask loading well. 
PLANT NAME : QUAD CITIES- 2

UT I LITY: COMMONWEALTH EDISON COMPANY

NEAREST TOWN: CORDOVA, I LL

NRC DOCKET NUMBER : $50-265$

REACTOR TYPE: BWR

RATING: (a) $809 \mathrm{MWe}$

IN PLANT HANDLING PARAMETERS:

Share Pool:(b) B

Preferred Cask: TN-9

Cask Experience:

Cask Crane Capacity, tons: 125 .

Crane Height, f $t:$ (c) 22.5

Pool Depth, ft: (d) 38.8

Pool Width, Et: (d) 9.0

Pool length, $f t:(d) 9.0$

COMMENTS: SEE COMMENTS; QUAD-CITIES-1.

RAIL / BARGE ACCESS DATA:

Rail Sput on Site: YES

Nearest railroad: MILWAUKEE

Distance from Rail Spur to Cask Loading Bay: 0 miles

Source of cooling water: MISSISSIPPI RIVER

Barge Feasibility: NO

COMMENTS: SEE COMMENTS; QUAD-CITIES-1.

CURRENT CASK HANDLING CAPABILITIES:

Legal Truck: YES

Overwe ight Truck: YES

Ra i 1: YES

(a) Spent Fuel Storage Requirements, DOE/RL-84-1, May 1984 .

(b) A indicates common pool shared by two reactors.

B indicates pools connected by transfer canal.

$C$ indicates pools connected by cask transfer.

(c) The distance from the operating deck to the bottom of the ctane hook at its uppermost position.

(d) Refers to the respective usable dimension (l.e., length. width, or depth) of the cask loading we!l. 
PLANT NAME: RANCHO SECO-1

UTILITY: SACRAMENTO MUNICIPAL UTILITY DISTRICT

NEAREST TOWN: CLAY STATION, CA

NRC DOCXET NUMBER: 50-312

REACTOR TYPE: PWR

RATING: (a) $913 \mathrm{MWe}$

IN PLANT HANDLING PARAMETERS:

Share Pool:(b) NO

Preferred Cask: SEE COMMENTS

Cask Experience:

Cask Crane Capacity, tons: 185

Crane Height, $f t:(c) 40$.

Poo! Depth, ft:(d) 44.5

Pool Width, ft: (d) 10.5

Pool length, ft: (d) 12.5

COMMENTS: RANCHO SECO WAS BUILT ASSUMINC A 100 TON CASK 6.8" DIA . \& $17^{\circ}$ LONG. THEREFORE THE PLANT SHOULD BE ABLE. TO HANDLE THIS SIZE CASK.

RA!L/BARGE ACCESS DATA:

Rail Spur on Site: YES

Nearest railroad: SOUTHERN PACIFlC

Distance from Rail Spur to Cask Loading Bay: 0 miles

Source of cooling water: FOLSOM CANAL

Barge Feasibility: NO

COMMENTS :

CURRENT CASK HANDLING CAPABILITIES:

Legal Truck: YES

Overweight Truck: YES

Ra1 1 : YES

(a) Spent Fuel Storage Requirements, DOE/RL-84-1, May 1984.

(b) A indicates common pool shared by two reactors.

B Indicates pools connected by transfer canal.

C indicates pools connected by cask transfer.

(c) The distance from the operating deck to the bottorn of the crane hook at its uppermost position.

(d) Refers to the respective usable dimension (i.e., length, width, or depthu of the cask loading well. 
PLANT NAME: RIVER BEND-1

UTILITY: GULF STATES UTILITIES

NEAREST TOWN: ST. FRANCISVILLE, LA

NRC DOCKET NUMBER: $50-458$

REACTOR TYPE: BWR

RATING : (a) $944 \mathrm{MWe}$

IN PLANT HANDLING PARAMETERS:

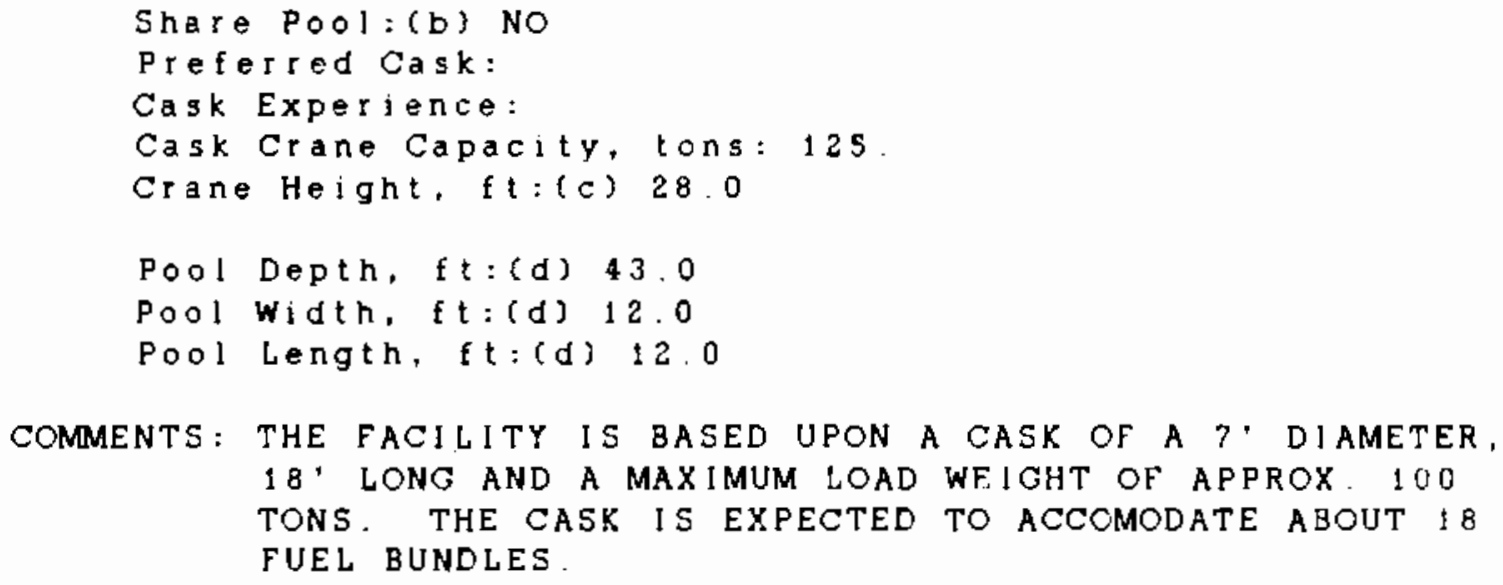

RAIL/BARGE ACCESS DATA:

Rail Spur on Site: YES

Nearest rail toad: UNKNOWN

Distance from Rall Spur to Cask Loading Bay: 0 miles Source of cooling water: MlSSISSIPPl RIVER

Barge Feasibility: YES

COMMENTS: THE FACILITY IS EQUIPPED TO SHIP TO AND FROM THE SITE ON A SPECIALLY DESIGNED RAIL CAR. SHIPPING BY BARGE IS ANOTHER POSSIBLITY, BUT THIS HASN'T BEEN EVALUATED.

CURRENT CASK HANDLING CAPABILITIES:

Legal Truek: YES

Overweight Truck: YES

Rail: YES

(a) Spent Fuel Storage Requirements, DOE/RL-84-1, May 1984.

(b) A indicates common pool shared by two reactors

B indicates pools connected by transfer.canal.

C indicates pools connected by cask transier.

(c) The distance from the operating deck to the bottom of the crane hook at its uppermost position.

(d) Refers to the respective usable dimension ( 1 , e., length. width, or depth) of the cask loading well. 
PLANT NAME: ROBINSON-2

UTILITY : CAROLINA POWER AND LIGHT CO.

NEAREST TOWN : HARTSVILLE, SC

NRC DOCKET NUMBER: $50-261$

REACTOR TYPE: PWR

RATING: (a) $665 \mathrm{MWe}$

IN PLANT HANDLING PARAMETERS:

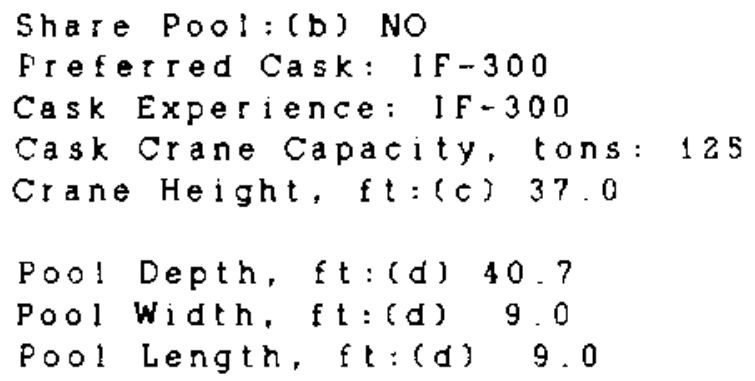

COMMENTS: IN ORDER TO MOVE THE CASK IN AND OUT OF THE FUEL STORAGE AREA, A ROOF PANEL AND A WALl, PANEL MUST BE REMOVEL.

THESE PANELS MUST BE IN PLACE DURING CASK LOADING/UNLOADING OPERATIONS

RAIL/BARGE ACCESS DATA:

Rail Spur on Site: YES

Nearest rail road: SEABOARD COASTLINE

[istance from Rail Spur to Cask Loading Bay: 0 miles

Source of cooling water: ROBINSON IMPOUNDMENT

Farge Feasibility: No

COMMENTS :

CURRENT CASK HANDLING CAPABILITIES:

l,egal Truck: YES

liverweight Truck: YES

F!a l l: YES

(a) Sipent Fue! Storage Requirements, DOE/RI-84-1, May 1984

(b) F. indicates common pool shared by two reactors.

H) indicates pools connected by transfer canal.

c'indicates pools connected by cask transfer.

(c) The distance from the operating deck to the bot tom of the : rane hook at its uppermost position.

(d) Refers to the respective usable dimension (i.e., length, width, or depth) of the cask loading well 
PLANT NAME: SALEM-1

UTILITY: PUBLIC SERVICE ELECTRIC AND GAS CO

NEAREST TOWN: SALEM, NJ

NRC DOCKET NUMBER: $50-272$

REACTOR TYPE: PWR

RATING : (a) $1079 \mathrm{MWe}$

IN PLANT HANDLING PARAMETERS:

Share Pool: (b) NO

Preferred Cask: NAC-1, NL $11 / 2$

Cask Experience:

Cask Crane Capacity, tons: 110

Crane Height, ft: (c) 30.5

Pool Depth, ft:(d) 45.0

Pool Width, it: (d) 12 . 0

Pool Length, ft: (d) 12.0

COMMENTS: SMALL COVER ( 9 'X9') ON DECONTAMINATION PIT BUT THIS COULD BE ENLARGED TO $19.5^{\prime} X 20^{\prime}$ BY REMOVAL OF A CHECXERBOARD PLATE. RECEIVING HATCH IS $30^{\prime} \mathrm{X} 10^{\prime}$

RAIL/BARGE ACCESS DATA:

Rail Spur on Site: No

Nearest railroad: CONRAIL

Distance from Rail Spur to Cask Loadang Bay: 15 miles

Source of cooling water: DELAWARE RIVER

Barge Feasibility: YES

COMMENTS: TURBINE ROTORS WERE BROUGHT TO SITE RECENTLY BY BARGE

\section{CURRET CASX HANDLING CAPABILITIES}

Legal Truck: YES

Overweight Truck: YES

Rail: NO

(a) Spent Fuel Storage Requirements, DoE/RL-34-1, May 1994

(b) A indicates common pool shared by two reactorE

$B$ indicates pools connected by transfer canal

$C$ indicates pools connected by cask transfer

(c) The distance from the operating deck to the bottorn of the crane hook at its uppermost position

(d) Refers to the respective usable dimension (i e, length, width, or depth) of the cask loading well 
PLANT NAME: SALEM-2

UTILITY: PUBLIC SERVICE ELECTRIC AND GAS CO.

NEAREST TOWN: SALEM, NJ

NRC DOCKET NUMEER: $50-311$

REACTOR TYPE: PWR

RATING: (a) $1106 \mathrm{MWe}$

IN PLANT HANDLING PARAMETERS

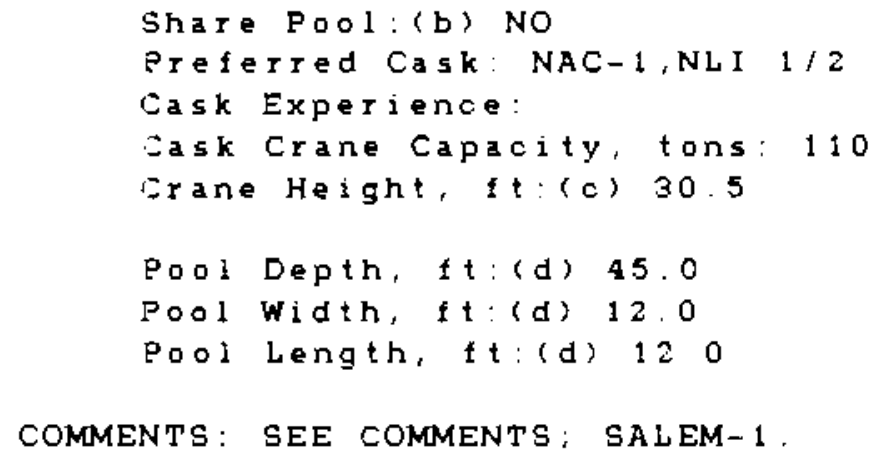

RAIL/GARGE ACCESS DATA:

Rail Spur on Site: NO

Nearest railroad: CONRAIL

Distance from Rail Spur to Cask Loading Bay: 15 miles

Source of cooling water: DELAWARE RIVER

उarge Feasibility: YES

COMMENTS: SEE COMMENTS; SALEM-1

\section{CURRENT CASX HANDLING CAPABILITIES}

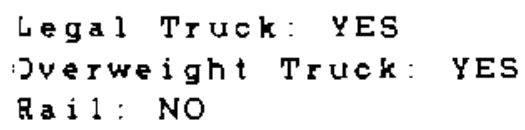

(a) Jpent Fuel Storage Requirements, DOE/RL-34-1, May 1984

(b) A indicates common pool shared by two reactors

$B$ indicates pools connected by transfer canal

C indicates pools connected by cask transfer

(c) The distance from the operating deck to the bottom of the crane hook at its uppermost position

(d) Refers to the respective usable dimension (i.e., length. width, or depth) of the cask loading well. 
PLANT NAME: SAN ONOFRE-1

UTILITY: SOUTHERN CALIFORNIA EDISON COMPANY

NEAREST TOWN: SAN CLEMENTE, CA

NRC DOCKET NUMBER: 50-200

REACTOR TYPE: PWR

RATING : (a) 387 MWe

IN BLANT HANDLING PARAMETERS

Share Poo 1: (b) C

Preterred Cask: IF-300, NAC-1

Cask Experience: NAC-1

Cask Crane Capacity, tons: 100

Crane Height, ft:(c) 65.0

Pool Depth, ft:(d) 40.0

Pool Width, ft: (d) 11.0

Pool Length, ft:(d) 11.0

COMMENTS: DID SOME PARTIAL SHIPMENTS FROM UNIT $₫$ IN 1921

RAIL/BARGE ACCESS DATA:

Rail Spur on Site: NO

Nearest railroad: ATCHisON, TOPEKA \& SANTA FE

Distance from Rail Spur to Cask Loading Bay: 0 miles source of cooling water: PACIFIC OCEAN

Barge Feasibility: NO

COMMENTS: USED TO BE RAIL SPUR INTO CASK LOADING BAY. HAS BEEN TORN UP AND ASPHALTED OVER. NOT LIKELY TO BE ANY WAY FOR A BARGE TO LAND

CURRENT CASK HANDLING CAPABILITIES

Legal Truck: YES

Overweight Truck: YES

Rail: NO

(a) Spent Fuel Storage Requirements, DOE'RL-84-1, May 1994

(b) A indicates common pool shared by two reactors

$B$ indicates pools connected by transfer canal

C indicates pools connected by cask transter

(c) The distance from the operating deck to the bottom of the crane hook at its uppermost position

(d) Refers to the respective usable dimension (i. e. Iength width, or depth) of the cask loading well 
PLANT NAME: SAN ONOFRE-2

UTILITY: SOUTHERN CALIFORNIA EDISON COMPANY

NEAREST TOWN: SAN CLEMENTE, CA

NRC DOCKET NUMBER: $50-361$

REACTOR TYPE : PWR

RATING: (a) $1100 \mathrm{MWe}$

IN PLANT HANDLING PARAMETERS:

Share Pool: (b) $C$

Preferred Cask: UNKNOWN

Cask Experience:

Cask Crane Capacity, tons: 125 .

Crane Height, $f t:(c) 32.0$

Pool Depth, ft: (d) 47.0

Pool width, ft: (d) 21.0

Pool Length, ft: (d) 23.0

COMMENTS: SEE COMMENTS : SAN ONOFRE-1.

\section{RAIL/BARGE ACCESS DATA:}

Rail Spur on Site: NO

Nearest railroad: ATCHISON, TOPEKA \& SANTA FE

Distance from Rail Spur to Cask Loading Bay: 0 miles

Source of cooling water: PACIFIC OCEAN

barge Feasibility: NO

COMMENTS: SEE COMMENTS: SAN ONOFRE-1.

CURRENT CASK HANDLING CAPABILITIES:

l.egal Truck: YES

Civerweight Truck: YES

Ra11: NO

(a) Spent Fuel storage Requirements, DOE/RL-84-1, May 1984.

(b) A indicates common pool shared by two reactors.

8 indicates pools connected by transfer canal.

C indicates pools connected by cask transfer.

(c) The distance from the operaling deck to the bottom of the crane hook at its uppermost position.

(d) Refers to the respective usable dimension $(i . e .$, length, width, or depthl of the cask loading well. 
PLANT NAME : SAN ONOFRE- 3

UTILITY: SOUTHERN CALIFORNIA EDISON CO.

NEAREST TOWN: SAN CLEMENTE, CA

NRC DOCKET NUMBER: $50-362$

REACTOR TYPE : PWR

RAT ING : (a) $1100 \mathrm{MWe}$

IN PLANT HANDLING PARAMETERS:

Share Pool: (b) $C$

Preferred Cask:

Cask Experience:

Cask Crane Capacity, tons: 125

Crane Height, $f t:(c) 32.0$

Pool Depth, t t:(d) 47.0

Pool Width, ft: (d) 21.0

Pool Length, $f t:(d) 23.0$

COMMENTS: SEE COMMENTS; SAN ONOFRE-1.

RAIL/BARGE ACCESS DATA:

Rail Spur on Site: NO

Nearest railroad: ATCHISON, TOPEKA AND SANTA FE

Distance from Rail 5pur to Cask Loading Bay: 0 mijes

Source of cooling water: PACIFlC OCEAN

Barge Feasibility:

COMMENTS: SEE COMMENTS; SAN ONOFRE-1.

CURRENT CASK HANDLING CAPABILITIES:

Legal Truck: YES

Overweight Truck: YES

Ra i 1: NO

(a) Spent Fuel Storage Requirements, DOE/RL-84-1, May 1984

(b) A indicates common pool shared by two reactors.

B indicates pools connected by transfer canal.

C indicates pools connected by cask transfer.

(c) The distance from the operating deck to the bottom of the crane hook at its uppermost position

(d) Refers to the respective usable dimension (i.e., length, width, or depthl of the cask loading well. 
PLANT NAME : SEABROOK-1

UT ILITY: PUBLIC SERVICE CO. OF NEW HAMPSHIRE

NEAREST TOWN : SEABROOK, NH

NRC DOCKET NUMBER : $50-443$

REACTOR TYPE: PWR

RATINO: (a) $1150 \mathrm{MWe}$

IN PLANT HANDLING PARAMETERS:

Share Paol: (b) NO

preferred Cask: NONE SPECIFIED

Cask Experience:

Qask Crane Capacity, tons: 125 .

Crane Height, f $t:$ (c) 39 .

Pool Depth, ft:(d) 46 .

Pool Width, ft: (d) 11 .

Pool Length, t t: (d) 11 .

COMMENTS: PLANT SHOULD BE ABLE TO HANDLE ANYTHING UP TO AN 8 . DIAMETER CASK

RAIL/BARGE ACCESS DATA:

Rajl Spur on Site: YES

Nearest rall road: BOSTON AND MAINE

Distance from Rail Spur to Cask Loading Bay: 0 miles Source of cooling water: ATLANTIC OCEAN

Barge Feasibility: NO

COMMENTS :

CURRENT CASK HANDLING CAPABILITIES:

segal Truck: YES

Overwelght Truck: YES

Rail : YES

(a) jpent Fuel Storage Requirements, DOE/RL-84-1, May 1984 .

(b) $A$ indicates common pool shared by two reactors.

3 indicates pools connected by transfer canal.

$C$ indicates pools connected by cask transter.

(c) The distance from the operating deck to the bottom of the crane hook at its uppermost position.

(d) Refers to the respective usable dimension (1.e., length, width, or depthl of the cask loading well. 
PLANT NAME : SEABROOK-2

UTILITY: PUBLIC SERVICE CO. OF NEW HAMPSHIRE

NEAREST TOWN : SEABROOK, NH

NRC DOCKET NUMBER: $50-444$

REACTOR TYPE : PWR

RATING: (a) 1150 MWe

IN PLANT HANDLING PARAMETERS:

Share Pool: (b) NO

Preferted Cask: NONE SPECIFIED

Cask Experience:

Cask Crane Capacity, tons: 125.

Crane Height. ft:(c) 39 .

Pool Depth, it: (d) 46 .

Poo! Width, $f t:(d) ~ t 1$.

Pool Length, ft: (d) 11 .

COMMENTS: SEE COMMENTS; SEABROOK-1.

\section{RAIL / BARGE ACCESS DATA:}

Rail Spur on Site: YES

Nearest raj!road: BOSTON AND MAINE

Distance from Rail Spur to Cask Loading Bay: 0 miles

Source of cooling water: ATLANTIC OCEAN

Barge Feasibility: NO

COMMENTS :

CURRENT CASK HANDLING CAPABILITIES:

Lega! Truck: YES

Overweight Truck: YES

Rai I: YES

(a) Spent Fuel Storage Requirements, DOE/RL-84-1, May 1984 .

(b) A indicates common poo! shared by two reactors.

B indicates pools connected by transfer canal.

C indicates pools connected by cask transfer.

(c) The distance from the operating deck to the bottom of the crane hook at its uppermost position.

(d) Refers to the respective usable dimension (i.e., length. width, or depthl of the cask loading well. 
PLANT NAME : SEQUOYAH-1

UTILITY: TENNESSEE VALLEY AUTHORITY

NEAREST TOWN: DAISY, TENN

NRC DOCKET NUMBER: $50-327$

REACTOR TYPE: PWR

RATING : (a) $1148 \mathrm{MWe}$

IN PLANT HANDLING PARAMETERS:

Share Pool: (b) A

Preferred Cask: SEE COMMENTS

Cask Experience:

Cask Crane Capacity, tons: 125 .

Crane Height, ft: (c) 32.5

Pool Depth, ft:(d) 25.0

Pool Width, ft: (d) 12.0

Pool Length, $f t:(d) 12.0$

COMMENTS: PLANTS BELIEVED CAPABLE OF HANDLING ALL TYPES OF CASKS.

RAIL/BARGE ACCESS DATA:

Rail Spur on Site: YES

Nearest rail ! rad: SOUTHERN RAILWAY SYSTEM

Distance from Rai! Spur to Cask Loading Bay: 0 miles

Source of cooling water: TENNESSEE RIVER

ヨarge Feasibility: YES

COMMENTS :

CURRENT CASK HANDLING CAPABILITIES:

jegal Truck: YES

Overweight Truek: YES

Rail: YES

(a) Jpent Fuel Storage Requirements, DOE/RL-84-1, May 1984.

(b) A indicates common pool shared by two reactors

B Indicates pools connected-by transfer canal.

C indicates pools connected by cask transfer.

(c) The distance from the operating deck to the bottom of the crane hook at its uppermost position.

(d) Refers to the respective usable dimension (j.e., length, width, or depthl of the cask loading well. 
PLANT NAME: SEQUOYAH-2

UT I LITY: TENNESSEE VALLEY AUTHORITY

NEAREST TOWN : DAISY, TENN

NRC DOCKET NUMEER: $50-328$

REACTOR TYPE : PWR

RAT ING : (a) $1148 \mathrm{MWe}$

IN PLANT HANDLING PARAMETERS:

Share Pool: (b) A

Preferred Cask: SEE COMMENTS

Cask Experience:

Cask Crane Capacity, tons: 129.

Crane Height, $f t:(c) 32.5$

Pool Depth, ft:(d) 25.0

Pool width, ft: (d) 12.0

Pool Length, $f t:(d) 12.0$

COMMENTS : SEE COMMENTS; SEQUOYAH-1.

RAIL/BARGE ACCESS DATA:

Rail Spur on Site: YES

Nearest rail road: SOUTHERN RAILWAY SYSTEM

Distance from Rail spur to Cask Loading Bay: 0 miles

Source of cooling water: TENNESSEE RIVER

Barge Feasibility: YES

COMMENTS: SEE COMMENTS $;$ SEQUOYAII- 1.

CURRENT CASK HANDLING CAPABILITIES:

Legal Truck: YES

Overweight Truck: YES

Rail: YES

(a) Spent Fuel storage Requirements, DOE:RL-84-1, May 1984 .

(b) A indicates common poo! ghared by two reactors.

B indicates pools connected by transier canal.

C indicates pools connected by cask transter

(c) The distance from the operating deck to the bottom of the crane hook at its uppermost position.

(d) Refers to the respective usable dimension (3.e., length, width, or depth) of the cask loading well 
PLANT NAME: SHOREHAM

UTILITY: LONG ISLAND LIGHTING COMPANY

NEAREST TOWN : BROOKHAVEN, NY

NRC DOCKET NUMBER: 50-322

REACTOR TYPE : BWR

RATINIS: (a) 8 I 9 MWe

IN PLANT HANDLING PARAMETERS:

Share Pool: (b) NO

Preferred Cask: TRUCK

Cagk Experience: NO

Qask Crane Capacity, tons: 125 .

Crane Height, $f t:(c) 26.3$

Pool Depth, ft:(d) 38.8

Poo: Width, ft:(d) 4.0

Pool Length, f $t:(d) 5.7 x$

COMMENTS: CASK POOL IS A 73 SQ.FT. QUADRANT OF THE SPENT FUEL POOL. PICTURE A RECTANGLE WITH A TRIANGLE TAKEN OUT OF ONE CORNER, WITH BOTTOM LENGTH $=10.5^{\prime}$, LEFT SIDE WIDTH $=7.8^{\circ}$, TOP ADJOINING LEFT CORNER $=5.7^{\prime}$, RIGHT SIDE ADJOINING LOWER RIGHT CORNER $=4.0^{\prime}$

RAIL/BARGE ACCESS DATA:

Rail Spur on Site: NO

Nearest railroad: LONG ISLAND $R$

Distance from Rail Spur to Cask Loading Bay: 10 miles

Source of cooling water: LONG 1SLAND SOUND

Barge Feasibility: YES

COMMENTS: HAVE HAD A TRAILER TRUCK IN BUILDING WHERE LOADING WOULD OCCUR. HAVE A DOCK ACCESSIBLE TO BARGE AND RECENTLY USED.

CURRENT CASK HANDLING CAPABILITIES:

Legal Truck: YES

כverweight Truck: NO

Ra i l : NO

(a) Spent Fuel Storage Requirements, DOE/RL-84-1, May 1984.

(b) A indicates common pool shared by two reactors

B indicates pools connected by transfer canal.

Cindicates pools connected by cask transfor.

(c) The distance from the operating deck to the botton of the crane hook at its uppermost position.

(d) Refers to the respective usable dimension (i.e., length, width, or depth) of the cask loading well 
PLANT NAME: SOUTH TEXAS PROJ-1

UTILITY: HOUSTON LIGHTING AND POWER COMPANY

NEAREST TOWN: PALACIUS, TX

NRC DOCKET NUMEER: $50-499$

REACTOR TYPE: PWR

RATING : (a) 1250 MWe

IN PLANT HANDLING PARAMETERS

Share Pool: (b) NO

Preferred Cask: NONE SPECIEIED

Cask Experience

Cask Crane Capacity, tons: 150

Crane Height, ft:(c) 29,0

Pool Depth, tt:(d) 41.0

Pool Width, tt: (d) 10.0

Pool length, ft: (d) 10.0

COMMENTS: CASK IS ALSO HANDLED BY A 145 TON CRANE OVER THE SPENT FUEL POOL. A DRY SPENT FUEL LOADING SYSTEM IS

USED. PLANT USES EXTRA LONG FUEL ASSEMBLIES

RAIL/BARGE ACCESS DATA

Ra i Spur on Site: YES

Nearest railroad: MrSSOURI PACIFIC

Distance from Rail Spur to Cask Loding Bay: 0 miles source of cooling water: COLORADO RIVER

Barge Feasibility: YES

COMMENTS :

CURRENT CASK HANDLING CAPABILITIES

Legal Truck: YES

Overweight Truek: YES

Rai l: YES

(a) Spent Fuel Storage Requirements, DOE/RL-g4-1, May 1984

(b) A indicates common pool shared by two reactors

$B$ indicates pools connected by transfer canal

$C$ indicates pools connected by cask transfer

(c) The distance from the operating deck to the bottom of the crane hook at its uppermost position.

(d) Refers to the respective usable dimension (i. e, length width, or depth) of the oask loading well

\section{A. 105}


PLANT NAME: SOUTH TEXAS PROJ -2

UTILITY: HOUSTON LIGHTING AND POWER COMPANY

NEAREST TOWN: PALACIOUS, TX

NRC DOCKET NUMBER: $50-499$

REACTOR TYPE: PWR

RAT ING : (a) $1250 \mathrm{MWe}$

IN PLANT HANDLING PARAMETERS:

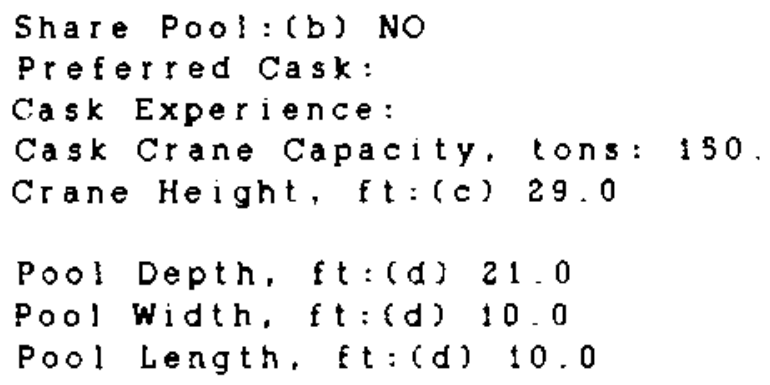

COMMENTS: SEE COMMENTS; SOUTH TEXAS PROJ . -1

RAIL/BARGE ACCESS DATA:

Rail spur on site: YES

Nearegt railroad: MISSOURI PACIFIC

Distance from Rail Spur to Cask Loading Bay: 0 miles Source of cooling water: COLORADO RIVER

Basge Feasibility: YES

COMMENTS :

CURRENT CASK HANDLING CAPABILITIES:

segal Truck: YES

Overweight Truck: YES

Rai l: YES

(a) Spent Fuel Storage Requirements, DOE/RL-84-1, May 1984

(b) A indicates common pool shared by two reactors.

B indicates pools connected by transfer canal.

C indicates pools connected by cask transfer.

(c) The distance from the operating deck to the bottom of the crane hook at its uppermost position.

(d) Refers to the respective usable dimenglon (1.e., length, width, or depthl of the cask loading wel!.

A. 106 
PLANT NAME: $5 T$. LUCIE-1

UTILITY: FLORIDA POWER AND LIGHT CO.

NEAREST TOWN: HUTCHINSON ISLAND, F

NRC DOCKET NUMBER: $\$ 0-335$

REACTOR TYPE: PWR

RATING: (a) $890 \mathrm{MWe}$

IN PLANT HANDLING PARAMETERS:

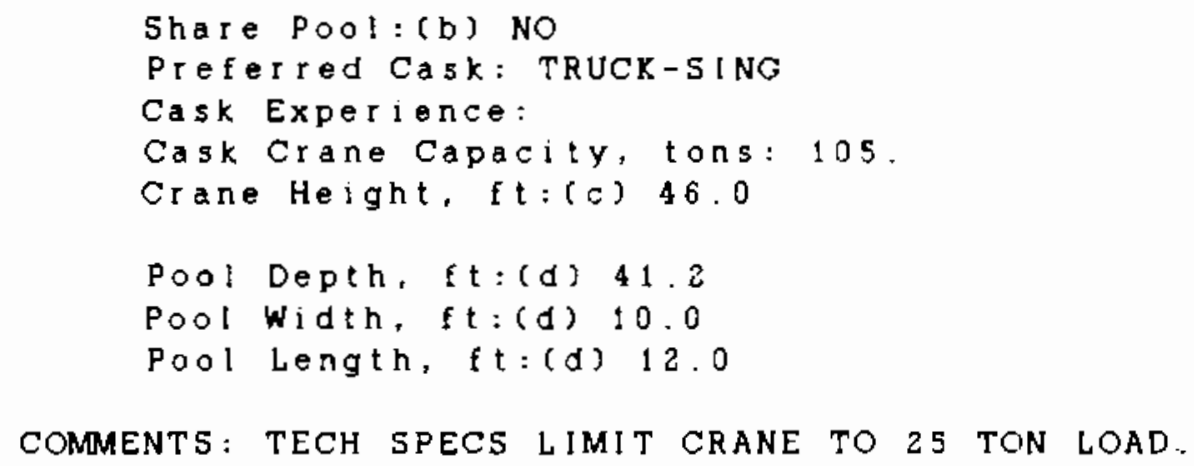

RAIL/BARGE ACCESS DATA:

Rai! Spur on Site: No

Nearest railroad: FLORIDA EAST COAST

Distance from Rail Spur to Cask Loading Bay: 5 miles

Source of cooling water: ATLANTIC OCEAN

Barge Feasibility: YES

COMMENTS: NO RAIL ACCESS TO HUTCHINSON ISLAND, BUT GOOD ACCESS BY BARGE ON INTERCOASTAL WATERWAY. HAVE HAD TRUCKS

ON ISLAND WIEGHING ABOUT 80,000 LBS

CURRENT CASK HANDLING CAPABILITIES:

Legal Truck: YES

Overwe ight Truck: NO

Rai 1: NO

(a) Spent Fuel storage Requirements, DOE/RL-B4-1, May 1984

(b) A indicates common pool shared by two reactors.

B indicates pools connected by transfer canal

C lndicates pools connected by cask transfer.

(c) The distance from the operating deck to the bottom of the crane hook at its uppermost positior.

(d) Refers to the respective usable dimension (i.e.. length. width, or depth) of the cask loading well. 
PLANT NAME: ST, LUCIE-2

UTILITY: FLORIDA POWER AND LIGHT CO.

NEAREST TOWN : HUTCHINSON ISLAND, F

NRC DOCKET NUMBER: 50-389

REACTOR TYPE : PWR

RATING: (a) $802 \mathrm{MWe}$

\section{IN PLANT HANDLING PARAMETERS:}

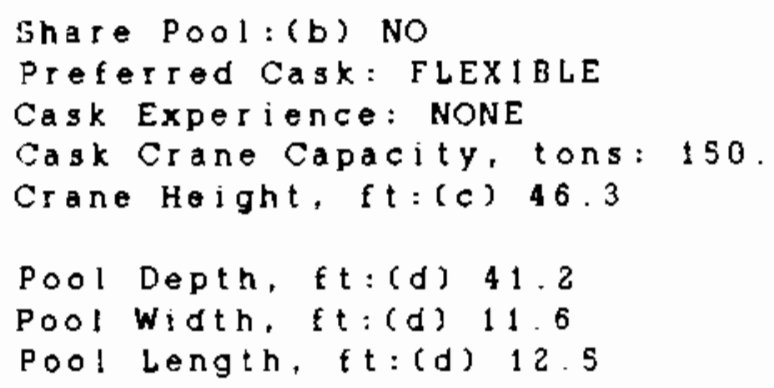

COMMENTS: 150 TON CRANE PROOF-TESTED AT $125 \%$ OF CAPACITY. COMPLETELY I SOLATED CASK AREA. LOADING POOL DIFFERS IN UNIT 2 FROM UNIT 1 .

RAIL/BARGE ACCESS DATA:

Rail Spur on Site: NO

Nearest rail load: FLORIDA EAST COAST

Distance from Rail Spur to Cask Loading Bay: 5 miles Source of cooling water: ATLANTIC OCEAN

3arge Feasibility: YES

COMMENTS: SEE COMMENTS; ST. LUCIE-1.

\section{CURREVT CASK HANDLING CAPABILITIES:}

Legal Truck: YES

Dverweight Truck: NO

Rai I: NO

(a) Spent Fuel storage Requirements, DOE/RL-84-1, May 1984.

(b) A indicates common pool shared by two reactors.

B indicates pools connected by transter canal.

C indicates pools connected by cask transfer.

(c) The distance from the operating deck to the bottom of the crane hook at its uppermost position

(d) Refers to the respective usable dimension (i.e., length. width, or depth) of the cask loading wel! 
PLANT NAME: SURRY - 1

UTILITY: VIRCINIA ELECTRIC POWER COMPANY

NEAREST TOWN: GRAVEL NECK, VA

NRC DOCKET NUMBER: $50-280$

REACTOR TYPE: PWR

RATING : (a) $775 \mathrm{MWe}$

IN PLANT HANDLING PARAMETERS:

Share Pool:(b) A

Preferred Cask: TN-8

Cask Exper lence: $\mathrm{TN}-8$

Cask Crane Capacity, tons: 125 .

Crane Height, f $t:$ (c) 29.0

Pool Depth, ft: (d) 40.5

Pool width, ft: (d) $\pm 2,0$

Pool length, $f t:(d) 12.0$

COMMENTS: UNITS $1 \& 2$ HAVE SINGLE ACCESS DOORS WHICH MUST BE CLOSED DURING CASK OPERATIONS. MAY BE SHIPPING WITH TN-9

IN NEAR FUTURE.

RAIL/BARGE ACCESS DATA:

Rail Spur on Site: NO

Nearest railraad: NORTH FORK AND WESTERN

Distance from Rail Spur to Cask Loading Bay: 26 miles

Source of cooling water: JAMES RIVER

Barge Feasibility: YES

COMMENTS :

CURRENT CASK HANDLING CAPABILITIES:

Legal Truck: YES

Overwejght Truck: YES

Rail : NO

(a) Spent Fue! Storage Requirements, DOE/RL-84-1, May 1984.

(b) A indicates common pool shared by two reactors.

B indicates pools connected by transfer canal.

C indicates pools connected by cask transfer.

(c) The distance from the operating deck to the bottom of the crane hook at its uppermost position.

(d) Refers to the respective usable dimension (j.e., length, width, or depth) of the cask loading well 
PLANT NAME: SURRY -2

UTILITY: VIRGINIA ELECTRIC POWER COMPANY

NEAREST TOWN : GRAVEL NECK, VA

NRC DOCKET NUMBER: $50-28$ :

REACTOR TYPE: PWR

RATING: (a) $775 \mathrm{MWe}$

\section{IN PLANT HANDLING PARAMETERS:}

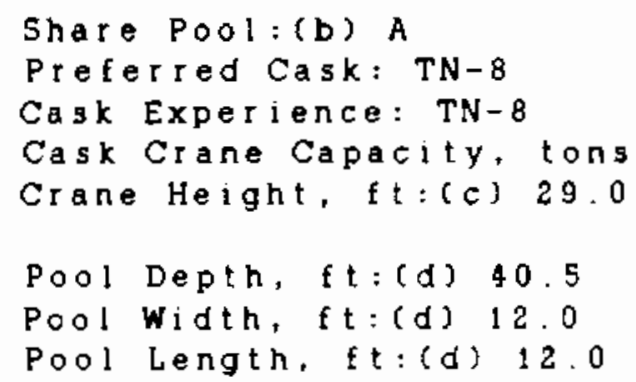

COMMENTS: SEE COMMENTS; SURRY-1.

RAIL/BARGE ACCESS DATA:

Rail Spur on site: NO

Nearest railroad: NORTH FORK AND WESTERN

Distance from Rail Spur to Cask Loading Bay: 26 miles Source of cooling water: JAMES RIVER

Barge Feasibility: YES

COMMENTS :

CURRENT CASK HANDLING CAPABILITIES:

Legal Truck: YES

Overweight Truck: YES

Rai 1: NO

\footnotetext{
(a) Spent Fuel Storage Requirements, DOE/RL-84-1, May 1984

(b) A indicates common pool shared by two reactors

B indicates pools connected by transfer canal.

C indicates pools connected by cask transfer.

(c) The distance from the operating deck to the bottom of the crane hook at its uppermost position.

(d) Refers to the respective usable dimension (i.e.. length, width, or depth) of the cask loading well.
}

\section{A. 110}


PLANT NAME: SUSQUEHANNA-1

UTILITY: PENNSYLVANIA POWER AND LIGHT CO

NEAREST TOWN : BERWICK, PA

NRC DOCKET NUMBER: $50-387$

REACTOR TYPE : BWR

RATING : (a) $1050 \mathrm{MWe}$

IN PLANT HANDLING PARAMETERS:

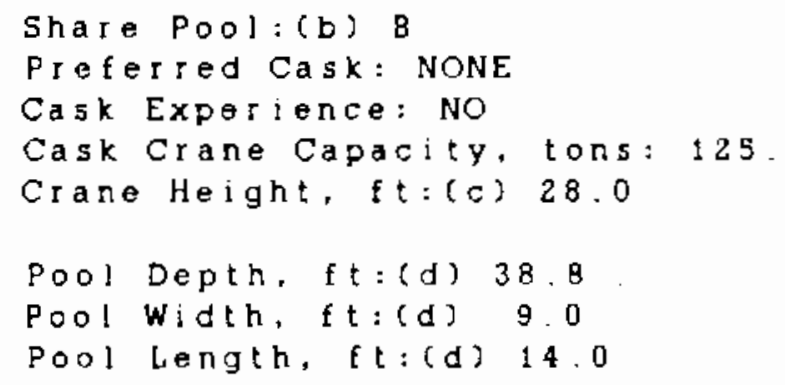

COMMENTS: UNITS 1 \& 2 EACH HAVE THEIR OWN POOL, BUT SHARE CASK HANDLING. POOL DIMENSIONS ARE 45' $\mathrm{X} 30^{\prime}$, NOTHINC. IS IN POOLS NOW, UNIT 1 IS STILL ON INITIAL CYCLE.

\section{RAIL/BARGE ACCESS DATA:}

Rail Spur on Site: YES

Nearest rall road: CONRAIL

Distance from Rajl Spur to Cask Loading Bay: 0 miles Source of cooling water: SUSQUEHANNA RIVFR

Barge Feasibility: NO

COMMENTS: UNSURE OF SIZE LIMITS ON SUSQUEHANNA RIVER; SOME THINCS WERE BROUGHT IN BY BOAT DURING CONSTRUCTION. NFW BRIDGE ON ROADS, PROBABLY IMPLIES NO UNUSUAL WEJGHT LIMITS.

\section{CURRENT CASK HANDLING CAPABILITIES:}

Lega! Truck: YES

Overweight Truck: YES

Rai l: YES

(a) Spent Fuel Storage Requirements, DOE/RL-84-1, May 1984.

(b) A indicates common pool shared by two reactors.

B Indicates poots connected by transfer canal.

C indicates pools connected by cask transfer.

(c) The distance from the operating deck to the bottom of the crane hook at its uppermost position.

(d) Refers to the respective usable dimension (l.e., length. width, or depthJ of the cask loading well. 
PLANT NAME: SUSQUEHANNA- 2

UTILITY: PENNSYLVANIA POWER AND LIGHT CO.

NEAREST TOWN : BERWICK, PA

NRC DOCXET NUMBER: $50-388$

REACTOR TYPE: BWR

RAT ING : (a) 1050 MWe

IN PLANT HANDLING PARAMETERS:

Share Pool:(b) 8

Preferred Cask: NO

Cask Experience: NO

Cask Crane Capacity, tons: 125.

Crane Height, ft: (c) 28.0

Pool Depth, ft:(d) 38.8

Pool Width, ft: (d) 9.0

Poo! Length, f $t:(d) 14.0$

COMMENTS: SEE COMMENTS; SUSQUEHANNA-1.

RAIL/BARGE ACCESS DATA:

Rail Spur on 5!te: YES

Nearest railroad: CONRAIl

Distance from Rail spur to Cask loading Bay: 0 miles

Source of cooling water: SUSQUEHANNA RIVER

Barge Feasibility: NO

COMMENTS: SEE COMMENTS; SUSQUEHANNA-1.

CURRENT CASK HANDLING CAPABILITIES:

Lega! Truck: YES

Jverweight Truck: YES

Ra:1: YES

(a) Spent Fuel Storage Requirements, DOE/RL-84-1, May 1984

(b) A indicates common pool shared by two reactors.

B indicates pools connected by transfer canal.

Cindicates pools connected by cask transfer.

(c) The distance from the operating deck to the bottom of the crane hook at its uppermost position.

(d) Refers to the respective usable dimension (i.e., length, width, or depthj of the cask loading well. 
PLANT NAME : THREE MILE ISLAND-1

UTILITY: GPU NUCLEAR

NEAREST TOWN : LONDONDERRY, TWP, PA

NRC DOCKET NUMBER: $\$ 0-289$

REACTOR TYPE: PWR

RAT!NG: (a) $776 \mathrm{MWe}$

IN PLANT HANDLING PARAMETERS:

Share Pool: (b) NO

Preferred Cask: NLI-10/24

Cask Exper jence: NONE

Cask Crane Capacity, tons: 110

Crane Height, ft: (c) 31.5

Pool Depth, ft:(d) 44.5

Pool width, ft:(d) 7.33

Poo! Length, ft: (d) 7.90

COMMENTS: DESIGN BASIS FOR POOL IS NLI-10/24100 TON CASK

RAIL/BARGE ACCESS DATA:

Ral! Spur on Site: YES

Nearest railroad: CONRAlL

Distance from Rail 5 pur to Cask loading Bay: 0 miles

Source of cooling wate $\mathrm{r}$ : SUSQUEHANNA RIVER

Barge Feasibility: NO

COMMENTS: RIVER IS TOO SHALLOW FOR BARGE WORK.

CURRENT CASK HANDLING CAPABILITIES :

Legal Truck: YES

Overweight Truck: YES

Ra i l: YES

(a) Spent Fuel Storage Requirements, DOE/RL-84-1, May 1984

(b) A indicates common pool shared by two reactors.

B lindicates pools connected by transfer canal.

c lndicates pools connected by cask t ransfer.

(c) The distance from the operating deck to the bot om of the crane hook at its uppermost position

(d) Refers to the respective usable dimension (j.e., length, width, or depth) of the cask loading well. 
PLANT NAME: THREE MILE ISLAND-2

UTILITY: GPU NUCLEAR

NEAREST TOWN : LONDONDERRY TWP, PA

NRC DOCKET NUMBER: 50-320

REACTOR TYPE: PWR

RAT ING : (a) 926 MWe

\section{IN PLANT HANDLING PARAMETERS:}

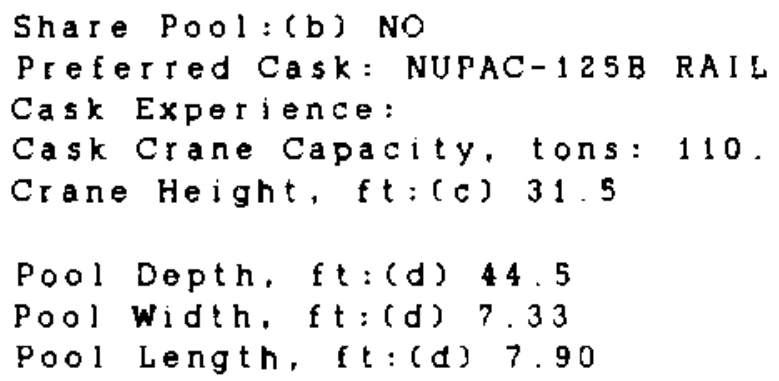

COMMENTS: DEWATERING STATION OCCUPIES FUEL POOL ORIGINALLY INTENDED FOR CASK TRANSFER. LOAD DROP ANALYSIS FOR 15 TON MAX. SO FAR BECAUSE OF LOCATION OF ELECTRICAL SAFETY SYSTEM.

RAIL/BARGE ACCESS DATA:

Rait Spur on Site: YES

Nearest rail road: CONSOLIDATED RAIL

Distance from Rail Spur to Cask Loading Bay: 0 miles Source of cooling water: SUSOUEHANNA R!VER

Barge Feasibility: NO

COMMENTS: SEE COMMENTS; THREE MILE ISLAND-1.

CURRENT CASK HANDL ING CAPABILITIES:

isega 1 Truck: YES

Overweight Truck: YES

Rail: YES

(a) Spent Fuel Storage Requirements, DOE/RL-84-1, May 1984

(b) A indicates common pool shared by two reactors.

$B$ indicates pools connected by transfer canal.

C indicates pools connected by cask transfer.

(c) The distance from the operating deck to the bottom of the crane hook at its uppermost position

(d) Refers to the respective usable dimension (1. e., length, width, or depth) of the cask loading well 
PLANT NAME: TROJAN

UTILITY: PORTLAND GENERAL ELECTRIC COMPANY

NEAREST TOWN : PRESCOTT, ORE

NRC DOCKET NUMBER: $50-344$

REACTOR TYPE : PWR

RATING : (a) 1080 MWe

IN PLANT HANDLING PARAMETERS:

Share Pool:(b) NO

Proferred Cask:

Cask Experience:

Cask Crane Capacity, tons: 125 .

Crane Height, $f t:(c) 30.0$

Pool Depth, ft: (d) 43.5

Pool Width, ft: (d) 9.0

Pool Length, ft: (d) 12.0

COMMENTS :

RAIL/BARGE ACCESS DATA:

Rail Spur on Site: NO

Nearest rail l rad: BURLINGTON NORTHERN

Distance from Rail Spur to Cask Loading Bay: 2 miles

Source of cooling water: COLUMBIA RIVER

Barge Fessibility: YES

COMMENTS: POTENTIAL RAILCAR LENGTH RESTRICTION ON RAILSPUR, HAS NOT BEEN EVALUATED. LOCATED ON COLUMBIA RIVER.

CURRENT CASK HANDLING CAPABILITIES:

Logal Truck: YES

Overweight Truck: YES

Rail: NO

(a) Spent Fuel Storage Requirements, DOE/RL-84-1, May 1984 .

(b) A indicates common pool shared by two reactors.

B indicateg pools connected by transfer canal.

C indicates pools connected by cask transfer.

(c) The distance from the operating deck to the bottom of the crane hook at its uppermost position.

(d) Refers to the respective usable dimension (i.o., length. width, or depth) of the cask loading well. 
PLANT NAME: TURKEY POINT-3

UTILITY: FLORIDA POWER AND LIGHT CO

NEAREST TOWN: FLORIDA CITY, FL

NRC DOCKET NUMBER: $50-250$

REACTOR TYPE: PWR

RATING: (a) $646 \mathrm{MWe}$

IN PLANT HANDLING PARAMETERS:

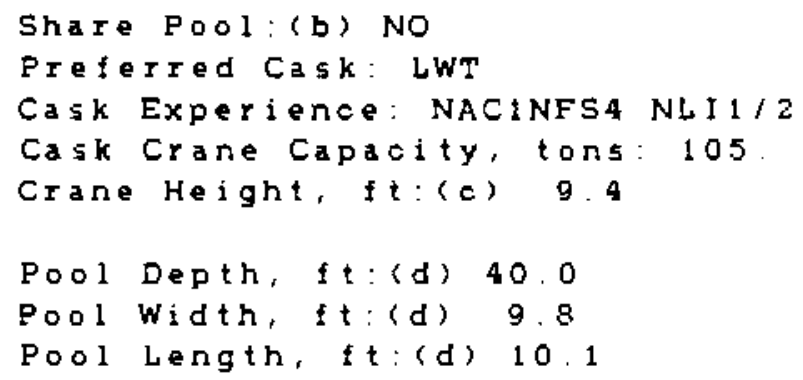

COMMENTS: TURXEY POINT UNITS ARE LIMITED BY LICENSE TO THE USE OF SINGLE ASSEMELY CASKS WITH A $25-T O N$ CASK WEIGHT LIMIT.

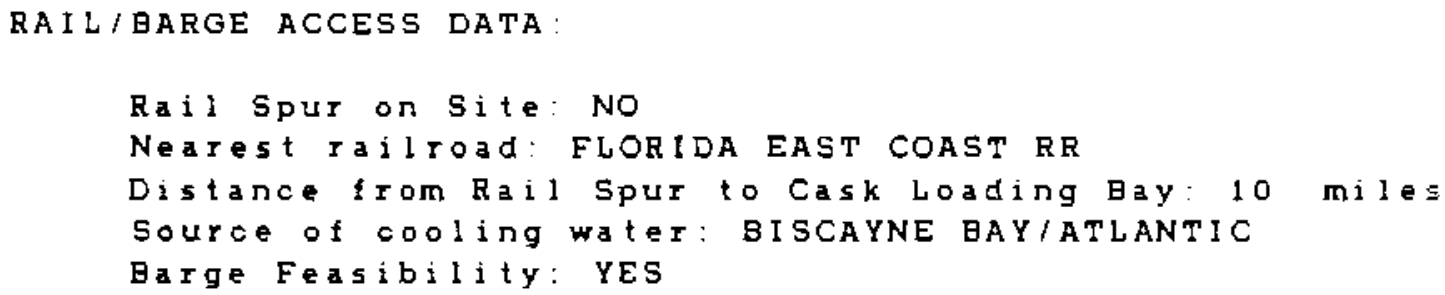

(a) Spent Fuel Storage Requirements, DOE/RL-34-1, May 1934

(b) A indicates common pool shared by two reactors

B indicates pools connected by transfer canal

$c$ indicates pools connected by cask transfer.

(c) The distance from the operating deck to the bot tom of the crane hook at its uppermost position.

(d) Refers to the respective usabledimension (i.e., length, width, or depth) of the cask loading well 
PLANT NAME TURKEY POINT-4

UTILITY: FLORIDA POWER AND LIGHT CO

NEAREST TOWN: FLORIDA CITY, FL

NRC DOCKET NUMBER: 50-251

REACTOR TYPE: PWR

RATING: (a) 646 MWe

IN PLANT HANDLING PARAMETERS

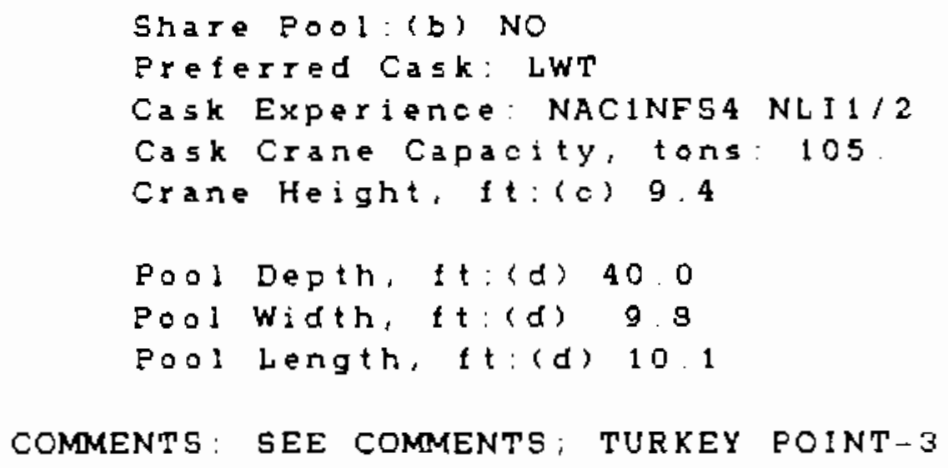

RAIL/BARGE ACCESS DATA:

Rail Spur on site: NO

Nearest railroad: FLORIDA EAST COAST

Distance from Rail Spur to Cask Loading Bay: 10 miles

Source of cooling water: BISCAYNE BAY/ATLANTIC

Barge Feasibility: YES

COMMENTS :

\section{CURRENT CASK HANDLING CAPABILITIES:}

Legal Truck: YES

Overweight Truck: NO

Ra i l: NO

\footnotetext{
(a) Spent Fuel Storage Requirements, DOE/RL-84-1, Magt 1934

(b) A indicates common pool shared by two reactors

B indicates pools connected by transfer canal

C indicates pools connected by cask transfer

(c) The distance from the operating deck to the bottom of the crane hook at its uppermost position.

(d) Refers to the respective usable dimension i i. e., length. width, or depth) of the cask loading well.
} 
PIANT NAME: VERMONT YANKEE

UTILITY: VERMONT YANKEE NUCLEAR ROWER CORP

NEAREST TOWN: VERNON, VT

NRC DOCKET NUMBER: $50-271$

REACTOR TYPE: BWR

RATING: (a) $5 \pm 4$ MWe

\section{IN PLANT HANDLING PARAMETERS:}

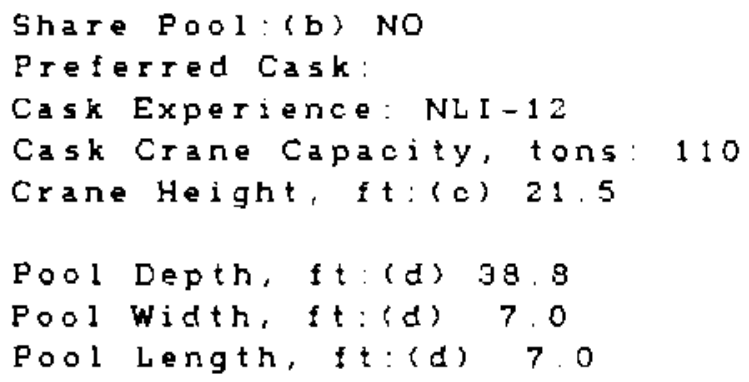

COMMENTS: PLANT DESIGNED FOR A IF-300 CASK- LARGEST PROBLEM IS PROBABLY DIMENSIONS, LOADING AREA TO PUT DOWN CASK IS ONLY $7^{\prime} X 7^{\prime}$, ALTHOUGH THIS PROBLEM CAN PROBAELY BE ELIMINATED.

RAIL/BARGE ACCESS DATA:

Rail Spur on Site: YES

Nearest railroad: VERMONT CENTRAL

Distance from Rail spur to Cask Loading Bey: 0 miles

Source of cooling water: CONNECTICUT RIVER

Barge Feasibility: NO

COMMENTS :

\section{CURREIT CASX HANDLING CAPABILITIES}

liegal Truck: YES

GVerweight Truck: YES

Ha i : YES

(a) Spent Fuel Storage Requirements, DOE/RL-o4-1, May $19 g 4$

(b) A indicates common pool shared by two reactors

B indicates pools connected by transfer canal

c indicates pools connected by cask transfer

(c) The distance from the operating deck to the bottom of the crane hook at its uppermost position

(d) Refers to the respective usable dimension ( $i$ e, leggth. width, or depth) of the cask loading well. 
PLANT NAME: VIRGIL C. SUMMER I

UTILITY: SOUTH CAROLINA ELECTRIC AND GAS CO

NEAREST TOWN : PARR, SC

NRC DOCKET NUMBER: 50.395

REACTOR TYPE : PWR

RAT ING : (a) $900 \mathrm{MWe}$

IN PLANT HANDLINO PARAMETERS:

Share Pool: (b) NO

Preferred Cask: NONE SPECIFIED

Cask Experience: NONE

Cask Crane Capacity, tons: 125

Crane Height, ft:(c) 31.5

Pool Depth, $f t:(d) 39.0$

Pool Width, ft: (d) 13.0

Pool Length, $f t:(d) 13.0$

COMMENTS: IT IS BELIEVED BY UTILITY PERSONNEL THAT THIS PLANT CAN HANDLE ANY CASK MADE SO FAR, INCUDINC ALL RAIL CASKS (NLI 10-24, ETC). PLANT IS DESIONED FOR 100 TON CASK.

RAIL/BARGE ACCESS DATA :

Rail Spur on Site: YES

Nearest railroad: SOUTHERN

Distance from Rail Spur to Cask Loading Bay: 0 miles Source of cooling water:

Barge Feasibility: NO

COMMENTS :

CURRENT CASK HANDLING CAPABILITIES:

Legal Truck: YES

Overweight Truck: YES

Ra 1! : YES

(a) Spent Fue! Storage Requirements, DOE/RL-84-1, May 1984 .

(b) A indicates common pool shared by two reactors.

B indicates pools connected by transfer canal.

C indicates pools connected by cask transfer.

(c) The distance from the operating deck to the bot om of the crane hook at lts uppermost position.

(d) Refers to the respective usable dimension ( 1. e., length, width, or depthl of the cask loading well. 
PLANT NAME : VOGTLE-1

UTILITY: GEORGIA POWER COMPANY

NEAREST TOWN: WAYNESBORO, GA

NRC DOCKET NUMBER: $50-424$

REACTOR TYPE: PWR

RATING: (a) $1110 \mathrm{MWe}$

IN PLANT HANDLING PARAMETERS :

Shate Pool:(b) B

Preferred Cask:

Cask Experience :

Cask Crane Capacity, tons: 125

Crane Height, Et: (c) 40.0

Pool Depth, ft:(d) 46.4

Pool Width, f t : (d) 13.4

Pool Length, ft: (d) 13.4

COMMENTS :

RAIL/BARGE ACCESS DATA:

Rail Spur on Site: YES

Neares! Iai!road: CENTRAL OF GEORGIA RAILROAD

Distance from Rail Spur to Cask Loading Bay: 0 miles

Source of cooling water: SAVANNAH RIVER

Barge Feasibility: YES

COMMENTS: PLANS ARE FOR DIRECT RAIL ACCESS. SKEPTICISM RE: BARGE TRANSPORT, ALTHOUGH 9 FOOT CHANNEL EXISTS.

CURRENT CASK HANDLING CAPABILITIES:

jegal Truck: YES

Jverweight Truck: YES

Rail: YES

(a) Spent Fuel Storage Requitements, DOE/RL-84-1, May 1984

(b) A indicateg common pool ghared by two reactors.

B indlcates pools connected by transfer canal.

Cindicates pools connected by cask transfer.

(c) The distance from the operating deck to the bottom of the crane hook at its uppermost position.

(d) Refers to the respective usable dimension (1.e., length, width. or deptht of the cask loading well.

A. 120 
PLANT NAME: VOGTLE-2

UTILITY: GEORGIA POWER COMPANY

NEAREST TOWN: WAYNESBORO, GA

NRC DOCKET NUMBER: $50-425$

REACTOR TYPE: PWR

RATINO:(a) $1110 \mathrm{MWe}$

IN PLANT HANDLING PARAMETERS:

Share Pool:(b) 8

Prefer red Cask:

Cask Experience: NONE

Cask Crane Capacity, tons: 125

Crane Hejght, ft:(c) 40.0

Pool Depth, ft: (d) 46.4

Pool width, ft: (d) 13.4

Pool Length, f $t:(d) 13.4$

COMMENTS :

RAIL/BARGE ACCESS DATA:

Rail Spur on Site: YES

Nearest railroad: CENTRAL OF GEORGIA RAILROAD

Distance from Rail Spur to Cask Loading Bay: 0 miles

Source of cooling water: SAVANNAH RIVER

Barge Feasibility: YES

COMMENTS: SEE COMMENTS; VOGTLE-1.

CURRENT CASK HANDLING CAPABILITIES:

Legal Truck: YES

Overweight Truck: YES

Ra i l : YES

(a) Spent Fuel storage Requirements, DOE/RL-84-1, May 1984.

(b) A indicates common pool shared by tro reactors.

B indicates pools connected by transfer canal.

C indicates pools connected by cask transfer

(c) The distance from the operating deck to the bottom of the crane hook at its uppermost position.

(d) Refers to the respective usable dimension (i.e., length, width, or depth) of the cask loading well. 
PLANT NAME: WATERFORD-3

UTILITY: LOUISIANA POWER AND LIGHT

NEAREST TOWN: TAFT, LA

NRC DOCKET NUMBER: $50-382$

REACTOR TYPE: PWR

RAT ING : (a ) 1104 MWe

IN PLANT HANDLING PARAMETERS :

Share Paol: (b) NO

Preferred Cask: NONE SPECIFlED

Cask Experience:

Cask Crane Capacity, tons: 125.

Crane Height, ft: (c) 29.5

Pool Depth, ft: (d) 45.5

Pool Width, ft: (d) 12.0

Pool Length, ft: (d) 13.0

COMMENTS: DERATED CRANE CAPACITY-?O. 5 TONS

RAIL/BARGE ACCESS DATA:

Rail Spur on Site: YES

Nearest railroad: MISSOURI PACIFIC

Distance from Rail Spur to Cask Loading Bay: 0 miles

Saurce of cooling water: MisSISSIPPI RIVER

Barge Feasibility: NO

COMMENTS :

CURRENT CASK HANDLING CAPABILITIES :

Legal Truck: YES

Dverweight Truck: YES

Rai l: NO

(a) Spent Fue! Storage Requirements, DOE/RL-gA-1, May 19R4.

(b) A indicates common pool shared by two reactors

B indicates pools cannected by transfer canal.

C indicates pools cannected by cask transfer.

(c) The distance from the operating deck to the bottom of the crane hook at lts uppermost position.

(d) Refers to the respective usable dimension (1.e., length, width, or depthl of the cask loading well. 
PLANT NAME: WATTS BAR-1

UTILITY: TENNESSEE VALLEY AUTHORITY

NEAREST TOWN: SPRING CITY, TENN

NRC DOCKET NUMBER: $50-390$

REACTOR TYPE : PWR

RAT ING : (a) 1177 MWe

IN PLANT HANDLING PARAMETERS:

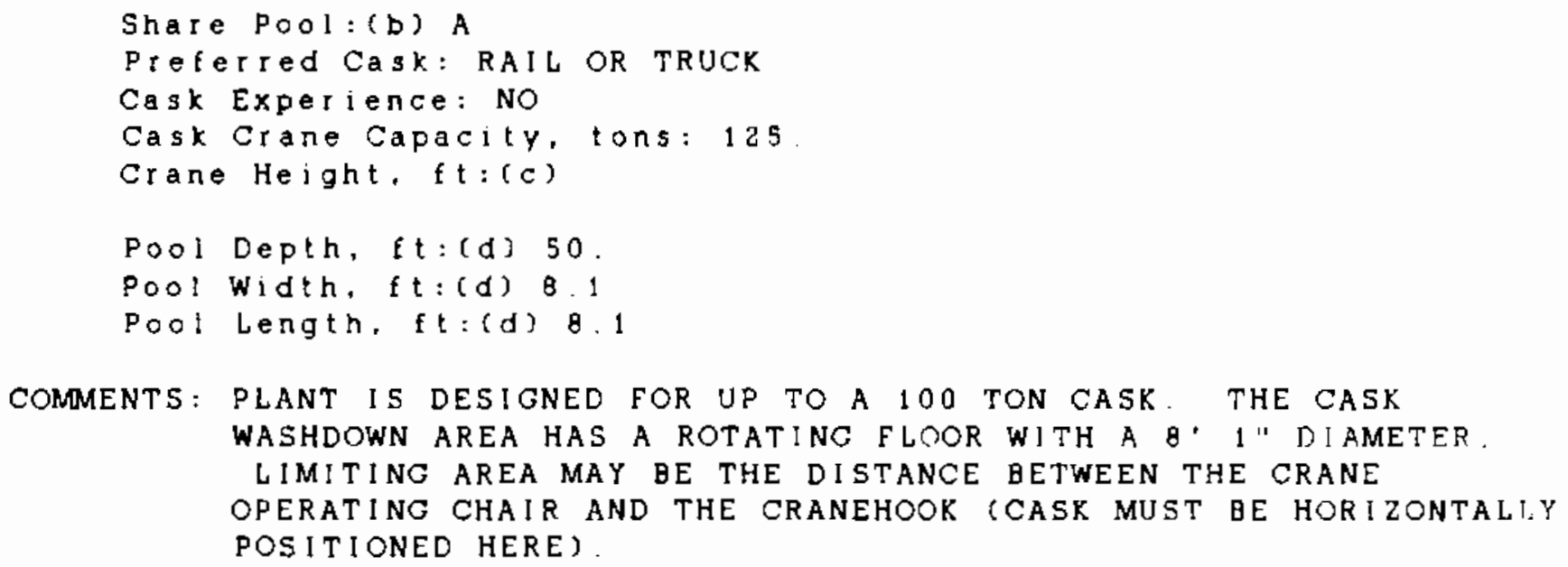

COMMENTS: PLANT IS DESIGNED FOR UP TO A 100 TON CASK. THE CASK

WASHDOWN AREA HAS A ROTATING FLOOR WITH A $8^{\circ} 1$ "DIAMETER.

LIMITING AREA MAY BE THE DISTANCE BETWEEN THE CRANE

OPERATING CHAIR AND THE CRANEHOOK (CASK MUST BE HORIZONTALI.Y POS ITIONED HERE)

RA IL / BARGE ACCESS DATA:

Rail Spur on 5ite: YES

Nearest rajlroad: SOUTHERN RAILWAY SYSTFM

Distance from Rail Spur to Cask Loading Bay: 0 miles

Source of cooling water: TENNESSEE RIVER

Barge Feasibility: YES

COMMENTS: DO NOT HAVE A BARGE LOADING FACILITY BUT ARE ON A LARGE WATERWAY (TENNESSEE RIVER ON LAKE CHICOMAUGUA) AND BROUGHT IN CONSTRUCTION MATERIALS BY BARGE

CURRENT CASK HANDLING CAPABILITIES :

Legal Truck: YES

Overwejght Truck: YES

Rail: YES

(a) Spent Fuel Storage Requirements, DOE/RL-84-1, May 1981.

(b) A indicates common pool shared by two reactors.

B indicates pools connected by transfer canal.

C indicates pools connected by cask transfer.

(c) The distance from the operating deck to the bottom of the crane hook at its uppermost position.

(d) Refers to the respective usable dimension (i.e., length, width, or depth) of the cask loading well. 
PLANT NAME : WATTS BAR -2

UTILITY: TENNESSEE VALLEY AUTHORITY

NEAREST TOWN: SPRING CITY, TENN

NRC DOCKET NUMBER: 50-391

REACTOR TYPE: PWR

RAT ! NG: (a) 1177 MWe

IN PLANT HANDLING PARAMETERS:

Share Pool: (b) A

Preferred Cask: NONE SPECIFIED

Cask Experience:

Cask Crane Capacity, tons: 125.

Crane Height, $f t:(c)$

Pool Depth, ft: (d) 50 .

Paol Width, ft: (d) 8.1

Pool Length, ft: (d) 8.1

COMMENTS: SEE COMMENTS; WATTS BAR-1.

RA!L/BARGE ACCESS DATA:

Rail Spur an Site: YES

Nearest railioad: SOUTHERN RAIL SYSTEM

Distance from Rail Spur to Cask Loading Bay: 0 miles

Source of cooling water: TENNESSEE RIVER

Barge Feasibility: YES

COMMENTS: SEE COMMENTS; WATTS BAR-1.

CURRENT CASK HANDLING CAPABILITIES:

Jegal Truck: YES

Overweight Truck: YES

Rai 1: YES

(a) Ipent Fuel Storage Requirements, DOE/RL-84-1, May 1984 .

(b) A indicates common pool shared by two reactars

a Indicates pools connected by transfer canal.

Cindicates pools connected by cast transfer.

(c) The distance from the operating deck lo the bottom of the crane hook at its uppermost position.

(d) Refers to the respective usable dimension (i.e., length, width, or depth) of the cask loading well 
PLANT NAME : WNP-1

UT I LITY: WASHINGTON PUBLIC POWER SUPPLY SYSTEM

NEAREST TOWN: RICHLAND, WA

NRC DOCKET NUMBER: $50-460$

REACTOR TYPE : PWR

RATING : (a) 1250 MWe

\section{IN PLANT HANDLING PARAMETERS:}

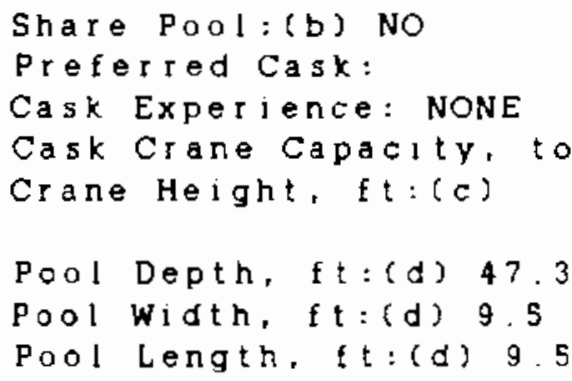

COMMENTS :

RA!L/BARGE ACCESS DATA:

Rail Spur on Site: YES

Nearest rallroad: GOVT. RR

Distance from Rail Spur to Cask Loading Ray: 0 miles

Source of cooling water: COLUMBIA RIVER

Barge Feasibil ity: YES

COMMENTS: GOVT. RAILROAD CONNECTING WITH BURLINGTON NORTHERN AND UNION PACIFIC.

CURRENT CASK HANDLING CAPABILITIES:

Legal Truck: YES

Overweight Truck: YES

Rail: YES

(a) Spent Fuel Storage Requirements, DOE/RL-84-1, May 1984.

(b) A indicates common poo! shared by two reactors.

B indicates pools connected by transfer canal

$C$ indicates pools connected by cask transfer.

(c) The distance from the operating deck to the bottom of the crane hook at its uppermost position.

(d) Refers to the respective usable dimension (1.e., length. width, or depth) of the cask loading well. 
PLANT NAME: WNP-2

UT!LITY: WASHINGTON PUBLIC POWER SUPPLY SYSTEM

NEAREST TOWN : RICHLAND, WA

NRC DOCKET NUMBER: $50-397$

REACTOR TYPE : BWR

RATING : (a) $1100 \mathrm{MWe}$

IN PLANT HANDLING PARAMETERS:

Shate Pool:(b) NO
Preferred Cask: NONE
Cask Experience: NO
Cask Ctane Capacity, to
Crane Height, ft:(c) 28
Pool Depth, ft:(d) 39.0
Pool Width, ft:(d) 8.0
Pool Length, ft:(d) 8.0

COMMENTS: CASK WELL IS AN $8^{\prime}$ OUTSIDE DIAMETER SHAFT IN THE SOUTHEAST OF THE SPENT FUEL POOL

RA! L/BARGE ACCESS DATA:

Rail Spur on Site: NO

Nearest railioad: GOVT RR

Distance from Rail Spur to Cask Laading Bay: .25 miles

5ource of cooling water: COLUMB!A RIVER

Barge Feasibulity: YES

COMMENTS: GOVT, RR CONNECTS WITH BURLINGTON NORTHERN AND UNION PACIFIC. RAILSPUR DOES NOT EXTEND INTO CASK LOADING BAY .

CURRENT CASK HANDLI NG CAPABILITIES :

Legal Truck: YES

()

F.ail: NO

(a) Sipent Fuel Storage Requirements, DOE/RL-84-1, May 1984.

(b) A indicates common pool shared by two reactors.

B indicates pools connected by transfer canal.

C indicates pools connected by cask tiansfer.

(c) The distance from the operating deck to the bottom of the crane hook at its uppermost position.

(d) Refers ta the respective usable dimension (i.e., length, width, or depth) of the cask loading we!l. 
PLANT NAME: WNP $\rightarrow 3$

UT ILITY: WASHINGTON PUELIC POWER SUFPLY SYSTEM

NEAREST TOWN: SATSOP, WA

NRC DOCKET NUMEER: $50-508$

REACTOR TYPE : PWR

RAT ING: (a) 1240 MWe

IN PLANT HANDLING PARAMETERS:

Share Pool: (b) NO

Preferred Cask:

Cast Experience:

Cask Crane Capacity, tons: 125.

Crane Height, $f t:(c)$

Pool Depth, ft:(d) 45.0

Pool Width, ft: (d) 12.0

Pool Length, ft: (d) 13.0

COMMENTS :

RAIL/BARGE ACCESS DATA:

Rail Spui on Sile: YES

Nearest rajlioad: BURLINGTON NORTHERN

Distance from Rai! Spur to Cask Loading Bay: 0 miles

Source of cooling water: CHEHALIS RIVER

Barge Feasibility: YES

COMMENT 5 :

CURRENT CASK HANDLING CAPABILITIES:

Legal Truck: YES

Overweight Truck: YES

Rail: YES

(a) Spent Fuel storage Requirements, DOE./RL-84-1. May 1984

(b) A indicates common pool shared by two reactors

B indicates pools connected by transfer canal.

C indicates pools connected by cask transfer.

(c) The distance from the operating deck to the bottom of the crane hook at its uppermost position.

(d) Refers to the respective usable dimension (i.e., length, width, or depthl of the cask loading well. 
PLANT NAME : WOLF CREEK

UT ILITY: KANSAS GAS AND ELECTRIC COMPANY

NEAREST TOWN: BURLINGTON, RANS

NRC DOCKET NUMBER: $50-482$

REACTOR TYPE: PWR

RATING: (a) $1128 \mathrm{MWe}$

IN PLANT HANDLING PARAMETERS:

Share Pool:(b) No

Preferred Cask: NONE SPEClF IED

Cask Experience:

Cask Crane Capacity, tons: 150.

Crane Height, f $t:(c) 33.6$

Pool Depth, ft:(d) 46.5

Pool Width, ft: (d) 14.0

Pool length, ft: (d) 14.0

COMMENTS :

RAIL/BARGE ACCESS DATA:

Rail Spur on Site: YES

Nearest railroad: MISSOUR! PAClFIC

Distance from Rail Spur to Cask Loading Bay: 0 miles

Source of cooling water: ARTIFICIAL COOLING LAKE

Barge Feasibility: NO

COMMENTS :

CURRENT CASK HANDLING CAPABILITIES:

Segal Truck: YES

Overweight Truck: YES

Rail: YES

(a) Spent Fuel Storage Requirements, DOE/RL-84-1. May 1984.

(b) A indicates common pool shared by two reactors

$B$ indicates pools connected by transfer canal.

C indicates pools connected by cask transfer.

(c) The distance from the operating deck to the bottom of the $c r a n e$ hook at its uppermost position.

(d) Refers to the respective usable dimension (i.e... length, width, or depth) of the cask loading well

$$
\text { A. } 128
$$


PLANT NAME: YANKEE

UTILITY: YANKEE ATOMIC ELECTRIC COMPANY

NEAREST TOWN: ROWE, MASS

NRC DOCKET NUMBER: $50-029$

REACTOR TYPE: PWR

RATING: (a) $185 \mathrm{MWO}$

IN PLANT HANDLING PARAMETERS:

Share Pool: (b) NO

Preferied Cask:

Cask Experience: WECX-300

Cagk Crane Capacity, tons: 35.0

Crane Height, ft: (c) 35.5

Pool Depth, ft: (d) 37.0

Pool Width, ft: (d) 5.0

Pool Length, $f t:(d) \quad 5.0$

COMMENTS: YANKEE IS HAVING SERIOUS PROBLEMS WITH THEIR CRANE, WHICH HAS BEEN DERATED TO 35 TONS FROM 60 TONS MUST MAKE MODIFICATIONS BEFORE LOADING. MAY GET SPECIAL ONE-TIME PERMIT TO LOAD. MAX. WIDTH \& LENGTH LIMITED BY 5 ' $X$ ' SETDOWN AREA; POOL MAY BE BIGGER

RAIL/BARGE ACCESS DATA:

Rail Spur on Site: NO

Nearest rai!road: BOSTON-MAINE RR

Distance from Rail Spur to Cask Loading Bay: 25 miles

Source of cooling water: DEERFIELD RIVER

Barge feasibility: NO

COMMENTS: YANKEE DID HAVE A RAILSPUR BUT IT HAS SINCE BEEN TAKEN OUT AND CANNOT BE REPLACED. ALSO, AREA AROUND ROWE, MA LOCATION IS HILLY, MAY OR MAY NOT BE A PROBLEM FOR TRUCKS.

CURRENT CASK HANDLING CAPABILITIES:

Legal Truck: YES

Overweight Truck: NO

Rail: NO

(a) Spent Fuel Storage Requirements, DOE/RL-84-1, May 1984

(b) A indicates common pool shared by two reactors.

B indicates pools connected by transfer canal.

C indicates pools connected by cask transfer.

(c) The distance from the operating deck to the bottom of the crane hook at its uppermost position

(d) Refers to the respective usable dimension (1.e.. length. width, or depths of the cask loading well. 
PLANT NAME: $2 I O N-1$

UTILITY: COMMONWEALTH EDISON COMPANY

NEAREST TOWN: ZION, ILL

NRC DOCKET NUMBER: $50-295$

REACTOR TYPE: PWR

RATING : (a) $1050 \mathrm{MWe}$

IN PLANT HANDLING PARAMETERS :

Share Pool:(b) A

Preferred Cask: NAC-1 NF5-4

Cask Experience: NLI-1/2

Cask Crane Capacity, tons: 125

Crane Height, ft:(c) 26

Pool Depth, ft:(d) 40.5

Pool Width, ft: (d) 8.3

Pool Length, ft: (d) 8.3

COMMENTS :

RAIL/BARGE ACCESS DATA:

Rail Spur on Site: YES

Nearest railroad: CHICAGO \& NORTHWESTERN

Distance from Rail Spur to Cask Loading Bay: 0 miles

Source of cooling ater: LAKE MICHIGAN

Barge Feasibility: YES

COMMENTS :

CURRENT CASK HANDLING CAPABILITIES:

Legal Truck: YES

Overweight Truck: YES

Rai l : YES

$\uparrow$

(a) Spent Fuel Storage Requirements, DOE/RL-84-1, May 1984 .

(b) A indicates common pool shared by two reactors.

B indicates pools connected by transfer canal.

C indicates pools connected by cask t $t$ anster.

(c) The distance from the operating deck to the bottom of the crane hook at its uppermost position

(d) Refers to the respective usable dimension (i.e.. length, width, or depth) of the cask loading well. 
PLANT NAME: ZION-2

UTILITY: COMMONWEALTH EDISON COMPANY

NEAREST TOWN: ZION, ILL

NRC DOCKET NUMBER: $50-304$

REACTOR TYPE: PWR

RAT ING : (a) $1050 \mathrm{MWe}$

IN PLANT HANDLING PARAMETERS:

Share Pool:(b) A

Preferred Cask: NAC-1/NFS-4

Cask Experience: NLI-1/2

Cask Crane Capacity, tons: 125

Crane Height, ft: (c) 26 .

Pool Depth, ft:(d) 40.5

Pool Width, ft: (d) 8.3

Pool Length, f $t:(d) 8.3$

COMMENTS :

RAIL/BARGE ACCESS DATA:

Rail Spur on Site: YES

Nearest railraad: CHICAGO \& NORTHWESTERN

Distance from Rail Spur to Cask Loading Bay: 0 miles

Source of cooling water: LAKE MICHIGAN

Barge Feasibility: YES

COMMENTS :

CURRENT CASK HANDLING CAPABILITIES:

Legal Truck: YES

Overweight Truck: YES

Rai 1: YES

(a) Spent Fue! Storage Requirements, DOE/Rb-84-1, May 1984 .

(b) A indicates common pool shared by two reactors.

B indlcates pools connected by transfer canal.

C indicates pools connected by cask transter.

(c) The distance from the operating deck to the bottom of the crane hook at its uppermost position

(d) Refers to the respective usable dimension (1.e., length, 
$*$ 
APPENOIX B

CHABACTERISTICS OF EXISTING SPENT FUEL SHIPPING CASKS 
APPENDIX B

\section{CHARACTERISTICS OF EXISTING SPENT FUEL. SHIPPING CASKS}

Three companles are currently providing spent fuel transportation casks: Nuclear Assurance Corp. (NAC), Transnuclear Inc. (TN), and General Electric Co. (GE). The characteristics of the shlpping casks provided by each of these companies are summarized in Table B.1. Additional information regarding these casks are presented in the following subsections.

TABLE B.1. Selected Characteristics of Existing Spent Fuel Shipping Casks Fuel Cask Prlmary Assemblies Empty External Number Number

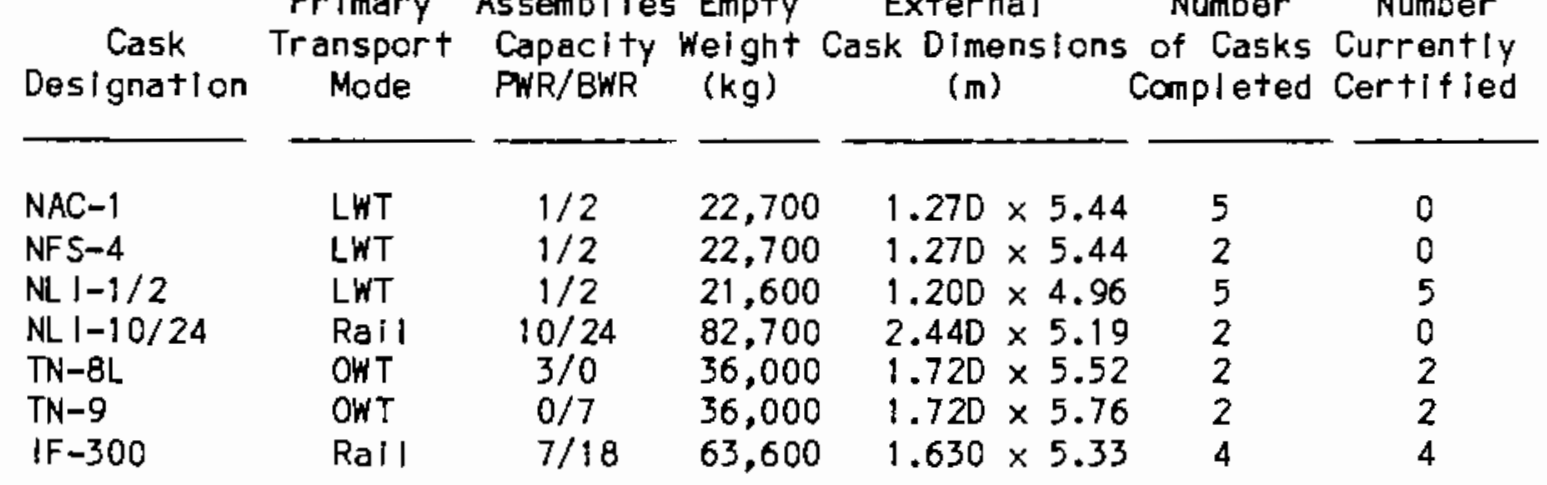

(a) Source of cask characteristIcs data; NUREG-0383 (NRC 1981b). Cask inventory data is from PNL-5284 (Daling 1984).

(b) LWT = legal-welght truck and OWT = overweight truck.

(c) NAC-i and NFS-4 are of the same design.

(d) Includes two NAC-1 casks that are owned by a utility.

(e) There are currently no internal baskets for these casks; therefore they are currently considered to be unavallable.

(f) Includes one $\mathrm{TN}-\mathrm{g}$ that is owned by a utlility.

(g) Includes on IF-300 that is owned by a utility.

Nuclear Assurance Corp.

NAC supplies a variety of legal-welght truck and rall shipping casks. Their truck cask fleet includes the NFS-4, NAC-1 (same design as the NFS-4), and the NLI-1/2 shipping casks. The rail cask supplied by NAC is the NL $1-10 / 24$ model. 
NAC elther owns or possesses long-term leases on all of their equipment IIsted on Table B.1. All seven of the NAC-1 and NFS-4 casks were temporarily suspended from used by the NRC in 1979. Two of the NAC-1 casks (one owned by NAC and one owned by a utllity) were declared not licensed pending reapproval of their Safety Analysis Report for Packaglng (SARP). These casks were modifled slightiy by the addition of some copper patches during the manufacturing process and the NRC had not revlewed and approved the modification. As a result, these two casks cannot be used for spent fuel shipments until NRC has reviewed and approved updated SARPs.

The remalning NAC-1 and NFS-4 shipping casks cannot be used at this time for spent fuel shipments because of an agrement between NRC and NAC. NAC has agreed not to use these casks because the NRC believes there is a potential for buckling of the internal cavity that could cause the lead shielding to change position. This could cause the radiation shielding to lose effectiveness at some location on the casks. Subsequent inspections of the casks showed no evidence of buckling or loss of ovality. However, NRC has asked NAC not to use these casks for spent fuel shipments pending further analyses. According to NAC, all of the NAC-i and NFS-4 shippIng casks will ultimately be recertifled.

NAC possesses long-term lease agreements for the $\mathrm{NLI}-10 / 24$ rail casks and NL1-1/2 LWT casks. These casks were previously supplled by NL Industries, Inc., who leased the casks to NAC in 1980. All five of the $N L 1-1 / 2$ casks are curren-ly certifled and operational. Both completed NLI-10/24 casks are curren-ly not avallable because of a lack of internal baskets. New baskets would have to be fabricated for these casks to become operational. If new basket:s are fabricated using the original design approved by NRC, little difficulty is expected on reactivating the casks. If the new baskets are designed differently, analysis and testing of the new design will be required. Submission of the safety analysis of a new basket design and subsequent review and approval by the NRC is also requited. 
Iransnuclear. lnc.

TN supplies the $T N-8 L$ and $T N-9$ OWT shipping casks. The TN-8L is designed to transport three PWR fuel assemblles; the $\mathrm{TN}-9$ has a design capacity of seven BWR assemblies. As shown in Table B.1, there are currently two TN-8L and two TN-9 casks in this country. One of the $\mathbb{T N}^{-9}$ shipping casks has been sold to Commonwealth Edison. The other three casks are owned by $\mathbb{N}$ and are certified and operational.

General Electric Coe

G.E. supplies the IF-300 rall shipping system. Currently there are four completed IF-300 casks. One is owned by a utility and three are owned by G.E. as shown in Table B.1. All of these casks are currently restricted to operating with dry internal cavities at reduced thermal capacities. Consequently, oniy long-cooled spent fuel may be shipped in the IF-300 as a full load. This reduces the flexibility of using these casks. However, since most of the fuel expected to be shipped in the future has cooled for extended periods, this ilmitation is not anticlpated to restrict the use of the cask in most instances.

As shown on Table B.1, the $\mid F-300$ is a substantially smaller rall cask system than the NLI-10/24 (i.e., the IF-300 has a smaller diameter and weighs less). For this reason, the $\mid F-300$ can be considered as a "ight" rail cask and the NLI-10/24 as a "heavy" rall cask. Due to this difference in size, some plants were determined to be capable of handling the IF-300 but not the NL 1-10/24. These plants were noted in Section 3.0 . 



\section{DISTRIBUTION}

No. of

Coples

\section{OFESITE}

30 U.S. Department of Energy Technical Information Center Oak RIdge, TN 37830

R. W. Bow $n$

Office of Civil ian Radicactive Waste Management

U.S. Department of Energy

$\mathrm{R} H-32$

Washington, D.C. 20545

S. H. Denny

Office of Civilian Radioactive Waste Management

U.S. Department of Energy $\mathrm{RH}-33$

Washington, D.C. 20545

F. P. Falcl, Jr. (2)

U.S. Department of Energy

DP-123

Washington, D.C. 20545

R. F. Garrison (2)

U.S. Department of Energy

$\mathrm{DP}-122$

Washington, D.C. 20545

J. Roger Hill ley

Office of Civilian Radicactive

Waste Management

U.S. Department of Energy

$\mathrm{R} w-30$

Washington, D.C. 20545

J. J. Jicha

U.S. Department of Energy

$\mathrm{DP}-123$

Washington, D.C. 20545
No. of

Coples

K. A. Klein

Office of Civllian Radicactive Waste Management

U.S. Department of Energy

$R H-3$ !

Wash ington, D.C. 20545

R. E. Philpott

Office of Civilian Radicactive Waste Management

U.S. Department of Energy

$\mathrm{RH}-33$

Washington, D.C. 20545

D. E. Shelor

Office of Civilian Radioactive Waste Management

U.S. Department of Energy

$\mathrm{RH}-32$

Washington, D.C. 20545

E. L. Wil mot

Office of Civllian Radicactlve Waste Management

U.S. Department of Energy

$\mathrm{R} N-33$

Washington, D.C. 20545

K. Gol il her (2)

U.S. Department of Energy

Albuquerque Operations Office

P.O. Box 5400

Albuquerque, NM 87115

J. M. McGough, Jr.

U.S. Department of Energy

Albuquerque Operations Office

P. 0. Box 5400

AIbuquerque, NM 87115 


\section{DISTRIBUTION}

No. of

Ceples

R. E. Luna

Division 6323

Sandia National Laborator les

P.0. Box 5800

Albuquerque, NM 87185

R. W. Lynch

Division 6300

Sandia National Laboratories

P.0. Box 5800

Albuquerque, NM 87185

J. F. Ney

Division 6320

Sandia National Laborator les

P.0. Box 5800

Albuquerque, NM 87185

M. A. Pound

Division 8214

Sandia National Laboratories

P. O. Box 5800

Albuquerque, NM 87185

T. L. Sanders

Division 6323

Sandia National Laboratories

P. O. Box 5800

A) buquerque, NM 87185

L. Scully

Division 6311

Sandla National Laboratorles

P. 0. Box 5800

A'buquerque, NM 87185

TTC LIbrary (5)

Division 6320

Sandla National Laborator les

P.O. Box 5800

A buquerque, NM 87185

W. E. Wowak

Division 6322

Sandia National Laboratories

P. 0. Box 5800

Aibuquerque, NM 87185
No. of

Cepies

T. H. Row

Oak Ridge Natlonal Laboratory

P. O. Box $X$

Oak Ridge, TN 37830

L. B. Shappert

Oak Ridge National Laboratory

P.O. Box $X$

Oak Ridge, TN 37830

B. M. Cole

Battel le Memorial Institute Wash ington Operations

$2030 \mathrm{M} \mathrm{Street}$ - NW

Sulte 800

Washington, D.C. 20036

J. Carr

Battelle Memorial institute $505 \mathrm{King}$ Avenue

Col umbus, $\mathrm{OH} 43201$

P. Hof fman

Battel le Memorial Institute

$505 \mathrm{King}$ Avenue

Col umbus, $\mathrm{OH} 43201$

M. Kehnemuyi

Battel le Memorial Instltute

$505 \mathrm{King}$ Avenue

Col umbus, $\mathrm{OH} 43201$

C. Kimm

Battel le Memorial Institute

$505 \mathrm{King}$ Avenue

Col umbus, $\mathrm{OH} 43201$

R. W. Peterson (2)

Battelle Memorial institute $505 \mathrm{King}$ Avenue

Col umbus, $O H \quad 43201$

R. V. Varadarajan

Battel le Memorial Institute

$505 \mathrm{King}$ Avenue

Col umbus, $\mathrm{OH} 43201$ 


\section{DISTRIBUTION}

No. of

Coples

W. C. Purchase

U.S. Department of Energy

Albuquerque Operations office

P. O. Box 5400

Albuquerque, NM 87115

G. Ishmae!

U.S. Department of Energy

Chicago Operations Office

g8u0 S. Cass Avenue

Argonne, IL 60459

S. Mann

U.S. Department of Energy

Chicago Operations office

9800 S. Cass Avenue

Argonne, IL 60439

J. 0 . Neff

National Waste Terminal Storage

Program

$505 \mathrm{King}$ Avenue

Col umbus, OH 42301

L. Casey

Natıonal Waste Terminal Storage Program

$505 \mathrm{King}$ Avenue

Col umbus, $\mathrm{OH} 42301$

C. Mathews

U.S. Department of Energy

Oak Ridge Operations Offlice

P.O. Box E

Oak Rldge, TN 37830

L. Blalock

U.S. Department of Energy

Oak Rldge Operations Office

P.O. Box E

Oak RIdge, $\mathrm{TN} 37830$

A. T. Newman

U. 5. Department of Energy

Nevada Operations Office

P.O. Box 14100

Las Vegas, NY 89114
No. of

Copies

D. L. Vieth

U. S. Department of Energy

Nevada Operatlons Offl $\mathrm{Ce}$

P.0. Box 14100

Las Vegas, NY 89114

J. Proletti

U.S. Department of Energy

Savannah River Operations Office

P.O. Box A

Alken, SC 29801

G. May

U.S. Department of Energy

Savannah Rlver Operations Office

P. 0. Box A

Alken, SC 29801

L. Turner

U.S. Department of Energy

Savannah River Operations Office

P. 0. Box A

Aiken, SC 29801

G. C. Allen (2)

Division 6323

Sandia National Laboratories

P.0. Box 5800

Albuquerque, NM 87185

J. W. Cashwell

Division 6323

Sandia National Laboratories

P.0. Box 5800

Albuquerque, NM 87185

L. J. Erickson

Division $314 i$

Sandia National Laboratorles

P.0. Box 5800

Albuquerque, NM 87185

T. O. Hunter

Division 6310

Sandia National Laboratorles

P. O. Eox 5800

Albuquerque, NM 87185 


\section{DISIRIBUTION}

No. of

Coples

R. F. W!II Ians

Electric Power Research Institute P.O. Box 10412

Palo Alto, CA 94304

R. M. Burgoyne

General Atomic Co.

10955 John Jay Hopkins Drive

San Diego, CA 92121

C. Boar dman

General Electr ic Co. 310 DeGuigne Dr.

Sunnyvale, CA 94086

E. R. Johnson

E. R. Johnson Associates, Inc.

11702 Bowman Green Drive

Reston, VA 22090

W. J. Lee

Nuclear Assurance Corp.

5720 Peachtree Parkway

Norcross, GA 30092

B. R. Teer

ransnuclear, Inc.

One North Broadway

White Plains, NY 10601
No, of

coples

Onsite

4 DOE Richland Operations Office

P. A. Cralg

D. E. Crouter

D. C. Langstatf

H. E. Ransom

2 Hanford Engineer Inc Development Laboratory

J. D. Berger

E. K. Opperman

3 Rockwell+Hanford Operations

K. H. Henry (2)

E. F. Yotaw

21 Pacifle Nor thwest Laboratory

P. M. Daling (5)

J. F. Fletcher

G. J. Konzek

A. J. Lezberg

R. C. Lilkala

G. W. McNair

D. F. Newman

R. E. Rhoads

K. J. Schnelder

M. R. Shay

Publishing Coordination MA (2)

Technical Information (5) 


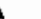

